\title{
Employment and Earnings of African Americans Fifty Years After: Progress?
}

\author{
Philip Moss, William Lazonick, and Joshua Weitz *
}

\author{
Working Paper No. 129
}

July $13^{\text {th }}, 2020$

\begin{abstract}
The Equal Employment Opportunity Commission (EEOC) was established in 1965 to implement Title VII of the Civil Rights Act of 1964, which made it illegal to discriminate against an individual in employment on the basis of race, color, religion, sex or national origin. Coming into the 1960s,

\footnotetext{
* William Lazonick is professor of economics emeritus, University of Massachusetts Lowell, and president of the Academic-Industry Research Network; Philip Moss is professor of economics emeritus, University of Massachusetts, and a research associate at the Academic-Industry Research Network; Joshua Weitz is a PhD candidate in political science at Brown University and a research associate at the Academic-Industry Research Network.

This INET working paper is a preliminary version of a chapter in a forthcoming book by William Lazonick, Philip Moss, and Joshua Weitz, Fifty Years After: Black Employment in the United States Under the Equal Employment Opportunity Commission. Other chapters will also appear as INET Working Papers.

Funded by the Institute for New Economic Thinking, the "Fifty Years After" project was launched in early 2016. The authors welcome comments on these working papers, which will undergo revision prior to finalizing the book manuscript. We thank Thomas Ferguson and Louis Ferleger for comments and Samantha Gable and Wynn Tucker provided research assistance.
} 
the employment opportunity that privileged the white male was much more than a job. By the 1960s, growing numbers of white men had employment that gave them steadily rising real earnings, often with decades of tenure at one organization. The "career-with-one-company" (CWOC) that had become the employment norm by the beginning of the 1960s included health insurance and a defined-benefit pension, both funded by the employee's business corporation or government agency. CWOC is what, in the decades immediately after World War II, turned much of white America into a growing and thriving middle class.

This was a white middle class made up of, at the lower end, blue-collar workers with no more than a high-school education. Union representation in collective bargaining enforced the unions' firsthired, last fired "seniority" principle while securing wage increases in step with productivity growth, with "cost-of-living allowances" that adjusted wages for inflation usually built into the contracts. Aided by government subsidies such as the federal GI Bill and tuition-free higher education at state "land grant" colleges, the male offspring of the white blue-collar worker had ample opportunity to transition to higher incomes, superior benefits, and even more employment security as a white-collar worker. In the 1950s, the white male who had recently ascended to the upper echelons of the middle class became known as "the organization man."

In the immediate aftermath of the 1964 Civil Rights Act, African Americans with no more than a high-school education gained access to CWOC employment at the blue-collar level. Owing to strong demand for production workers in the 1960s and 1970s and affirmative-action support under the EEOC, Blacks were making inroads into white-male privilege by gaining substantial access to well-paid and secure operative and craft occupations; big steps up from the common-laborer jobs into which they had previously been segregated. In the first Working Paper of this series https://www.ineteconomics.org/research/research-papers/how-the-disappearance-of-unionizedjobs-obliterated-an-emergent-black-middle-class, we outlined how the decline of unionized jobs from the beginning of the 1980s decimated an emergent African American blue-collar middle class. Over the decades it became clear, however, that, while African Americans were hit earlier and harder than whites, they were not the only ones to fall out of the middle class. Increasingly, white blue-collar workers with no more than a high-school education also lost their middle-class status as the ideology that companies should be run to "maximize shareholder value" put a permanent end to the CWOC norm. Over subsequent decades and up to the present, growing numbers of American workers with only a high-school education, regardless of race, have experienced stagnating incomes, downward socioeconomic mobility, and even, at certain times, declining life expectancy.

In this, the second working paper of our Fifty Years After book manuscript, we provide a statistical overview of the changes in employment and earnings of Blacks since the mid-1960s. If Title VII of the Civil Rights Act of 1964, along with other anti-discrimination laws from that period, and the formation of the Equal Employment Opportunity Commission promised progress toward racial equality in employment and general well-being, the current situation shows a very troubling picture. Across all dimensions of economic well-being that are dependent on access to decent paying, secure jobs, Blacks fare worse than whites. We present the most recent available data on the occupations (for 2019) and the industries (for 2018) in which the different Black, white, Hispanic, and Asian members of the U.S. labor force are employed. Then, using the decennial censuses, we examine the distributions of Blacks across aggregate categories of occupations from 1960 to 2010 to see the changing pattern of jobs held by Blacks, in broad terms, from the time of 
the Civil Rights Act to the present. We then look at the differences in Black and white unemployment and wage rates, with and without accounting for differences in education. The racial gap in wages, after accounting for education level, has widened.

Stable jobs that enable employees to share in productivity gains and hence increase their real earnings over time facilitate the accumulation of wealth. In its various forms, wealth influences the current and future well-being of families and their children by enabling investments in education and training, providing savings to offset unforeseen circumstances, and funding retirement. Although manifest progress has been made by a portion of better-educated Blacks, the overall picture for wealth accumulation by Blacks in comparison with whites is grim. A race-based wealth gap should be no surprise, as access of African Americans to stable, well-paid jobs has always been much less than for whites. Yet, the size of wealth disparities is extremely large and has worsened over the last fifty years. Currently the median family wealth for whites is ten times that of Blacks. We examine the wealth gap within separate categories, including housing equity, housing stability measured by delinquency on mortgages and foreclosure, retirement savings and liquid savings, corporate shareholding, and student-loan debt. We also look at health insurance coverage because it functions, in part, like savings that can be called upon to deal with unanticipated events. And lack of health insurance can wipe out one's accumulated wealth should one require hospitalization and/or expensive drugs. In every one of these components of wealth, Blacks trail whites by large and increasing amounts. Each of these indicators reflects the persistent and even growing Black-white disparities in earnings, employment security, and career patterns over time.

Which leaves us with the question that the "Fifty Years After" project seeks to answer: What happened to equal employment opportunity? For a quest for economic equality to become a reality, the pay and stability of employment for Blacks must be improved far more than for whites. But in view of the downward mobility of white workers, even a substantial closing of the Black-white income gap will not solve the problems of poverty and injustice in the United States. Contrary to the situation in the 1960s, in the presence of the impoverished and vulnerable American working class of the 2020s, "equal employment opportunity" will not yield the upward socioeconomic mobility for Blacks that was possible in the 1960s and 1970s. The Covid-19 crisis is having an especially devastating impact on people of color, but workers of every race and ethnicity are feeling immense pain. Even when the public-health crisis has abated, the gargantuan political task for the years and decades ahead will be the restoration of employment opportunity that will enable all Americans to live healthy, secure, and happy lives.

\section{https://doi.org/10.36687/inetwp129}

JEL Codes: D2, D3, G3, J0, L2, L6, N8, O3, P1

Keywords: African American, occupations, industries, education, employment opportunity, employment relations, income distribution, wealth accumulation, stock buybacks 


\section{Productivity, pay, and the distribution of income}

What we expect from the economy is stable and equitable economic growth. We want real gains in per capita productivity that can raise living standards. We want the members of the labor force to have stable employment and income, not subject to boom and bust, that can sustain a decent living standard over four or five decades of one's working life with sufficient funds saved for two, or even three, decades of retirement. We want the gains from growth to be shared equitably among those people who contribute to it, with the equitable use of the planet's resources across nations and over generations.

In the decades after World War II, the U.S. economy exhibited the promise of stable and equitable growth, or what can be called "sustainable prosperity." Figure II.1, taken from a New York Times article by David Leonhardt, using data from U.S. income-tax returns compiled by economists Thomas Piketty and Emmanuel Saez, compares changes in real income by percentile of the U.S. income distribution in 1980 for the period 1946 to 1980 and in 2014 for the period 1980 to 2014. In the first 34-year period, there is a clear trend toward income equality, with the greatest income growth at the lowest percentiles of the 1980 distribution. In the following 34-year period, there is clear-cut evidence of extreme income inequality, with the greatest gains at the highest percentiles of the 2014 distribution.

\section{Figure II.1: Real income growth in the United States by percentiles of the income distributions in 1980 and 2014 over the previous 34-year periods}

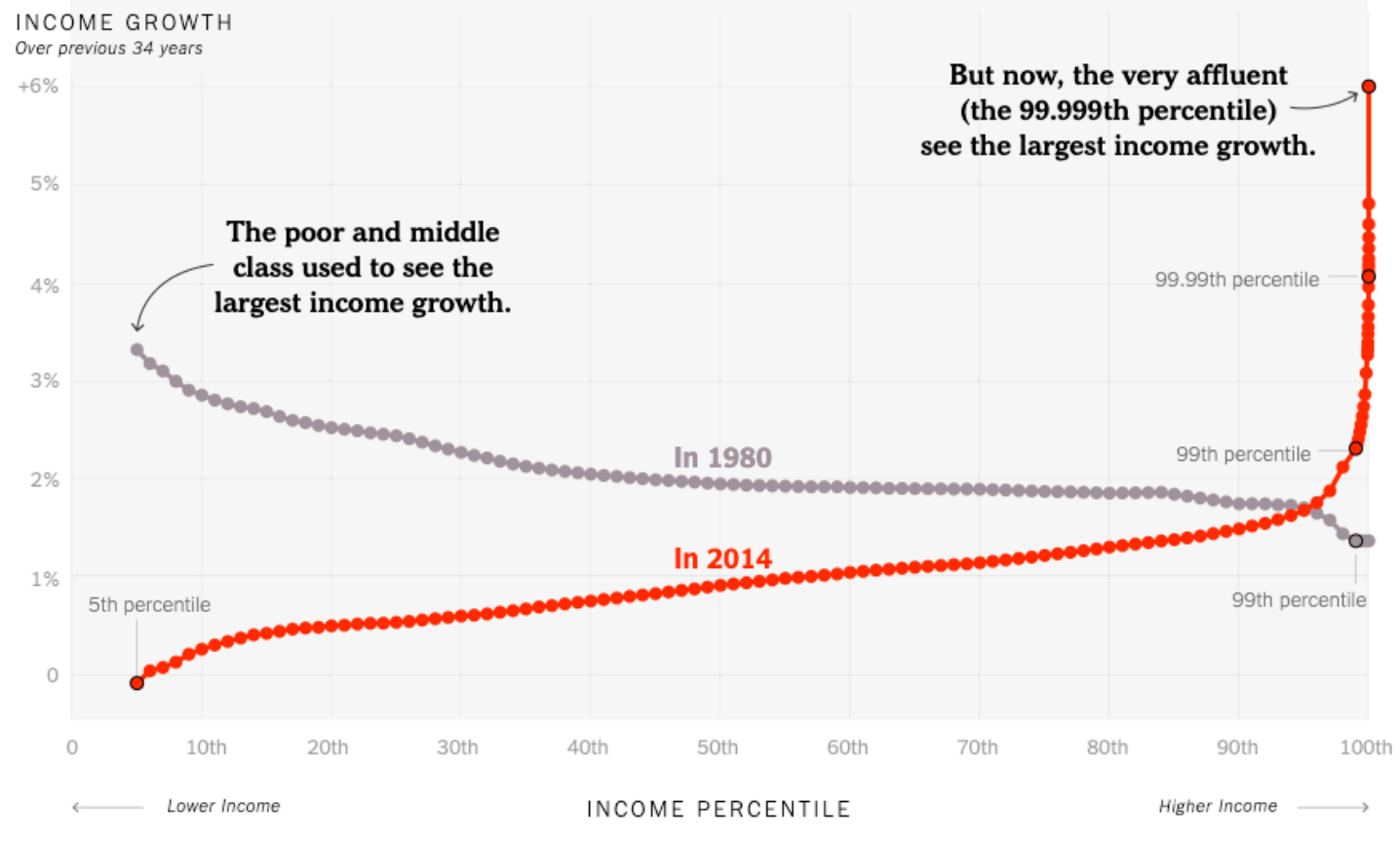

Note: Inflation-adjusted annual average growth using income after taxes, transfers and non-cash benefits.

Source: David Leonhardt, "our broken economy, in one simple chart," New York Times, August 7, 2017, at https://www.nytimes.com/interactive/2017/08/07/opinion/leonhardt-incomeinequality.html

\footnotetext{
${ }^{1}$ William Lazonick, Sustainable Prosperity in the New Economy? Business Organization and High-Tech Employment in the United States, Upjohn Institute for Employment Research, 2009, ch. 1, at https://research.upjohn.org/up press/13/.
} 
A key determinant of this change in income distribution was a change in the relationship between real wage growth and labor-productivity growth in the earlier era compared with the later era, as shown by a well-known graph from the Economic Policy Institute, reproduced as Figure II.2. From 1948 to about the mid-1970s, the percentage growth in real wages tracked the percentage growth in productivity, whereas in the following decades there was a growing gap between productivity growth and wage growth.

\section{Figure II.2: Percentage changes in productivity per our worked and real hourly} wages in the United States, 1948-2018

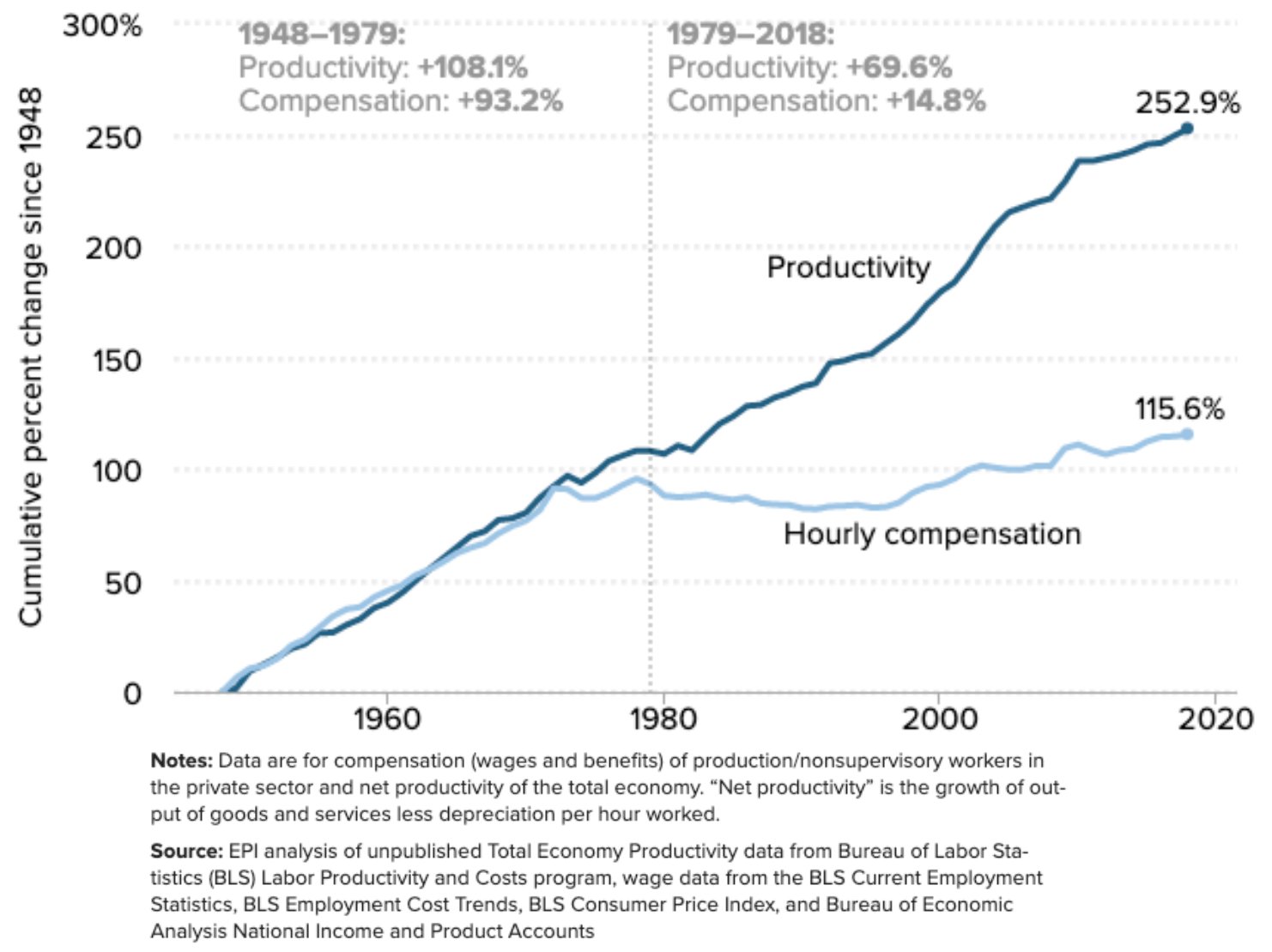

Source: Economic Policy Institute, “The Productivity-Pay Gap,” July 2019, at https://www.epi.org/productivity-pay-gap/.

It is in this growing gap between productivity and pay that we can find a prime explanation for concentration of income among the richest households from the 1980s, as indicated in Figure II.1. ${ }^{2}$ As we explained in Working Paper \#1 of this series, ${ }^{3}$ we attribute the close link between

\footnotetext{
${ }^{2}$ See William Lazonick, "Labor in the Twenty-First Century: The Top 0.1\% and the Disappearing Middle Class," in Christian E. Weller, ed., Inequality, Uncertainty, and Opportunity: The Varied and Growing Role of Finance in Labor Relations, Cornell University Press, 2015: 143-192.

${ }^{3}$ William Lazonick, Philip Moss, and Joshua Weitz, "How the Disappearance of Unionized Jobs Obliterated an Emergent Black Middle Class," Institute for New Economic Thinking Working Paper No. 125, June 2020, at

https://www.ineteconomics.org/research/research-papers/how-the-disappearance-of-unionized-jobs-obliterated-an-emergentBlack-middle-class.
} 
productivity and pay growth in the decades after World War II to the adherence of major corporations to the employment norm of a career-with-one-company (CWOC) for both blue-collar and white-collar workers. Profitable companies, and in particular those that grew large and came to dominate their industries, retained a substantial portion of their profits and used them a) to reward employees with increases in pay, benefits, and employment stability for contributing their skill and effort to helping to create those profits, and b) to invest in the productive capabilities, both human and physical, to develop the next generation of successful products that could sustain the firm as a value-creating enterprise.

It was, we argue, this "retain-and-reinvest" corporate resource-allocation regime that raised the incomes of employees, underpinning the emergence of a growing and thriving middle class. These rising wages did not make the firms that paid them less profitable as long as the rising living standards were based on an ongoing virtuous productivity-pay dynamic within these firms, as captured by Lazonick's theory of innovative enterprise. ${ }^{4}$ Jobs characterized by rising wages, superior benefits, and stable employment provided by the leading business corporations in turn placed pressure on other firms as well as government agencies to provide similar employment opportunities in order to attract and retain labor services. Meanwhile, a progressive tax structure funded government investment in infrastructure and knowledge that supported the operations of business firms and the greatly enhanced education of the U.S. labor force. ${ }^{5}$

As we document in our Fifty Years After project, the CWOC employment norm that prevailed in the post-World War II decades placed white males in privileged positions. It enabled the growth of a white middle class made up of, at the lower end, blue-collar workers with no more than highschool educations. Union representation in collective bargaining enforced the unions' first-hired, last fired "seniority" principle while securing wage increases in step with productivity growth, usually with "cost-of-living allowances" that compensated for inflation built into the contracts. Aided by government subsidies such as the federal GI Bill and tuition-free higher education at state "land grant" colleges, the male offspring of the white blue-collar worker had ample opportunities to transition to higher incomes, superior benefits, and even more employment security as white-collar workers - entering the upper echelons of the middle class as what Fortune editor William H. White called "the organization man."

We also show that in the 1960s and 1970s, Blacks began to gain access to the middle class as a strong demand for blue-collar labor and the effective implementation of equal employment opportunity legislation enabled Blacks to obtain operative and craft jobs in mass-production industries. These positions were big steps up from the common-laborer jobs into which they had

\footnotetext{
${ }^{4}$ See William Lazonick, "The Innovative Firm," in Jan Fagerberg, David Mowery, and Richard Nelson, eds., The Oxford Handbook of Innovation, Oxford University Press, 2005: 29-55; William Lazonick, "The Theory of Innovative Enterprise: Methodology, Ideology, and Institutions," in Jamee K. Moudud, Cyrus Bina and Patrick L. Mason, eds., Alternative Theories of Competition: Challenges to the Orthodoxy, Routledge, 2012: 127-159; William Lazonick, "Is the Most Unproductive Firm the Foundation of the Most Efficient Economy?: Penrosian Learning Confronts the Neoclassical Fallacy," Institute for New Economic Thinking Working Paper No.111, January 31, 2020, at https://www.ineteconomics.org/research/research-papers/isthe-most-unproductive-firm-the-foundation-of-the-most-efficient-economy-penrosian-learning-confronts-the-neoclassicalfallacy.

${ }^{5}$ See Matt Hopkins and William Lazonick, "Who Invests in the High-Tech Knowledge Base?" Institute for New Economic Thinking Working Group on the Political Economy of Distribution Working Paper No. 6, September 2014 (revised December 2014), at http://ineteconomics.org/ideas-papers/research-papers/who-invests-in-the-high-tech-knowledge-base.

${ }^{6}$ William H. Whyte Jr., The Organization Man, Simon \& Schuster, 1956.
} 
previously been segregated. The employment foundation was put in place for the emergence of a black blue-collar middle class.

From the early 1980 s, however, at companies where CWOC was central to employment, there was a transformation of the dominant corporate resource-allocation regime from "retain-andreinvest" to "downsize-and-distribute," 7 as these companies closed plants, laid off workers, and suppressed pay increases, while increasing distributions to shareholders in the form of not only cash dividends but also stock buybacks. This focus on "maximizing shareholder value," which became an explicit ideology of U.S. corporate management from the mid-1980s, ${ }^{8}$ concentrated income gains in the bank accounts of the richest households, providing an explanation of the epochal changes in the distribution of income depicted in Figure II.1 and II.2.

Downsize-and-distribute resulted in not only stagnating wages but also destruction of the CWOC norm. ${ }^{9}$ In a survey of changes in job security from the 1970s to the 2000s, Henry Farber states: "There is ample evidence that long-term employment [with one company] is on the decline in the United States." ${ }^{10}$ Using Current Population Survey data, he finds that

mean tenure for males employed in the private sector has declined substantially, particularly for older workers. For example, mean tenure for private sector males at age fifty declined from 13.5 years in the 1973 to 1983 period to 11.3 years in the 1996 to 2008 period. The pattern in the public sector is the opposite. For example, mean tenure for public sector males at age fifty increased from 13.6 years in the 1973 to 1983 period to 15.8 years in the 1996 to 2008 period..$^{11}$

Education as a guarantor of employment security weakened significantly from the 1980s to the 2000s. Using Displaced Worker Survey data to analyze rates of job loss, Farber writes:

In 1981 to 1983, the private-sector three-year job loss rate was 16 percent for high school graduates and 9.4 percent for college graduates. By 2001 to 2003 (also a period of weak labor markets), the gap had fallen to virtually zero, with a private-sector threeyear job loss rate of 10.7 percent for high school graduates and 11 percent for college graduates. Interestingly, the education gap in job loss rates increased in the 2005 to 2007 period with 8.3 and 10.0 percent job loss rates for high school and college graduates, respectively..$^{12}$

\footnotetext{
7 William Lazonick and Mary O'Sullivan, "Maximizing Shareholder Value: A New Ideology for Corporate Governance," Economy and Society, 29, 1, 2000: 13-35; Lazonick, "Labor in the Twenty-First Century"; William Lazonick, "Stock Buybacks: From Retain-and-Reinvest to Downsize-and-Distribute," Center for Effective Public Management, Brookings Institution, April 2015, pp. 10-11, at http://www.brookings.edu/research/papers/2015/04/17-stock-buybacks-lazonick.

8 Johan Heilbron, Jochem Verheul, and Sander Quak, "The Origins and Early Diffusion of 'Shareholder Value' in the United States," Theory and Society, 43, 1, 2014: 1-22.

9 Lazonick, Sustainable Prosperity in the New Economy?; Lazonick, "Labor in the Twenty-First Century"; See William Lazonick, Philip Moss, Hal Salzman, and Öner Tulum, "Skill Development and Sustainable Prosperity: Cumulative and Collective Careers versus Skill-Biased Technical Change", INET Working Paper Number 15, December 2014, at https://www.ineteconomics.org/research/research-papers/skill-development-and-sustainable-prosperity-cumulative-andcollective-careers-versus-skill-biased-technical-change.

${ }^{10}$ Henry Farber, "Job Loss and the Decline of Job Security in the United States," in Katharine G. Abraham, James R. Spletzer, and Michael Harper, eds. Labor in the New Economy, University of Chicago Press, 2010: 223-262.

${ }^{11}$ Ibid., p. 230

${ }^{12}$ Ibid., p. 253.
} 
The decimation of CWOC afflicted Blacks with only high-school educations sooner and harder than whites, but over the decades increasing numbers of white blue-collar workers with no more than high-school educations also lost their middle-class status as the rise to dominance of the ideology that companies should be run to "maximize shareholder value" put a definitive end to the CWOC norm. Over subsequent decades to the present, growing numbers of U.S. workers with only a high-school education experienced stagnating incomes, downward socioeconomic mobility, and even, at certain times, declining life expectancy..$^{13}$

As shown in Table II.1, the proportion of the U.S. labor force with no more than a high-school education remains large. For the population 25 years and over in 2018, 38.7 percent had a highschool diploma (or GED equivalent) or less. Non-Hispanic whites were below that average for the whole population, but 33.7 percent of them had not advanced beyond a high-school diploma. For Blacks, this figure was 45.0 percent and for Hispanics 59.3 percent, with the extraordinarily high percentage of Hispanics lacking an elementary or high school diploma or GED resulting from the relatively recent immigration of Hispanic adults with low levels of education. ${ }^{14}$ Asians had more education, in part because of U.S. immigration policy, as analyzed in Working Paper \#5.

The widespread prevalence of low-paid work in the U.S. economy by race and educational attainment, among other dimensions, has been documented in a recently released Brookings study that covers 350 metropolitan areas the years 2012 through $2016 .{ }^{15}$ As summarized by the authors Martha Ross and Nicole Bateman:

Low-wage workers comprise a substantial share of the workforce. More than 53 million people, or $44 \%$ of all workers ages 18 to 64 in the United States, earn low hourly wages. More than half (56\%) are in their prime working years of 25-50, and this age group is also the most likely to be raising children (43\%). They are concentrated in a relatively small number of occupations, and many face economic hardship and difficult roads to higher-paying jobs. Slightly more than half are the sole earners in their families or make major contributions to family income. Nearly one-third live below $150 \%$ of the federal poverty line (about $\$ 36,000$ for a family of four), and almost half have a high school diploma or less.

\footnotetext{
${ }^{13}$ We will examine this subject in more detail in a later Working Paper. See also Servaas Storm, "The New Normal: Demand, Secular Stagnation, and the Vanishing Middle Class," International Journal of Political Economy, 46, 4, 2017: 169-210; James K. Galbraith, “A Comment on Servaas Storm's 'The New Normal',' International Journal of Political Economy, 46, 4, 2017: 211-216; William Lazonick, "The New Normal is 'Maximizing Shareholder Value': Predatory Value Extraction, Slowing Productivity, and the Vanishing American Middle Class," International Journal of Political Economy, 46, 4, 2017; 217-226; Servaas Storm," The New Normal: Demand, Secular Stagnation, and the Vanishing Middle Class: A Reply to James K. Galbraith and William Lazonick," International Journal of Political Economy, 46, 4, 2017: 227-232.

${ }^{14}$ See, however, Luis Noe-Bustamante, "Education levels of recent Latino immigrants in the U.S. reached new highs as of 2018," Pew Research Center, April 7, 2020, at https://www.pewresearch.org/fact-tank/2020/04/07/education-levels-of-recent-latinoimmigrants-in-the-u-s-reached-new-highs-as-of-2018/.

${ }^{15}$ Martha Ross and Nicole Bateman, "Meet the Low-Wage Workforce," Brookings Institution Metropolitan Policy Program, November 7, 2019, at https://www.brookings.edu/research/meet-the-low-wage-workforce/.
} 
Table II.1: Education level attained by people, 25 years of age and over, by race and ethnicity, 2018

\begin{tabular}{|c|c|c|c|c|c|c|c|c|c|c|}
\hline \multirow{2}{*}{ Education level attained } & \multicolumn{2}{|c|}{ All groups } & \multicolumn{2}{|c|}{ Non-Hispanic White } & \multicolumn{2}{|c|}{ Black } & \multicolumn{2}{|c|}{ Asian } & \multicolumn{2}{|c|}{ Hispanic } \\
\hline & Number & Percent & Number & Percent & Number & Percent & Number & Percent & Number & Percent \\
\hline Total, 25 years and over (in thousands) & 219,830 & 100 & 142,420 & 100 & 27,047 & 100 & 13,677 & 100 & 33,877 & 100 \\
\hline Elementary or High school, no diploma & 22,412 & 10.2 & 8,127 & 5.7 & 3,263 & 12.2 & 1,298 & 9.6 & 9,627 & 28.5 \\
\hline Elementary or High school, GED & 6,120 & 2.8 & 3,942 & 2.7 & 917 & 3.5 & 105 & 0.7 & 986 & 3.0 \\
\hline High school diploma & 56,564 & 25.7 & 36,068 & 25.3 & 7,924 & 29.3 & \begin{tabular}{l|l}
2,498 \\
\end{tabular} & 18.3 & 9,425 & 27.8 \\
\hline HIGH SCHOOL OR LESS & 85,096 & 38.7 & 48,137 & 33.7 & 12,104 & 45.0 & 3,901 & 28.6 & 20,038 & 59.3 \\
\hline & & & & & & & & & & \\
\hline College, no degree & 33,941 & 15.5 & 22,516 & 15.8 & 5,111 & 18.9 & 1,061 & 7.8 & 4,620 & 13.7 \\
\hline Associate's degree, vocational & 9,647 & 4.4 & 6,829 & 4.8 & 1,138 & 4.2 & 351 & 2.7 & 1,132 & 3.4 \\
\hline Associate's degree, academic & 12,722 & 5.7 & 8,729 & 6.0 & 1,646 & 6.1 & 548 & 4.0 & 1,598 & 4.8 \\
\hline HIGH SCHOOL BUT NO COLLEGE DEGREE & 56,310 & 25.6 & 38,074 & 26.6 & 7,895 & 29.2 & 1,960 & 14.5 & 7,350 & 21.9 \\
\hline & & & & & & & & & & \\
\hline Bachelor's degree & 48,235 & 21.9 & 34,513 & 24.2 & 4,415 & 16.3 & 4,297 & 31.4 & 4,414 & 13.0 \\
\hline Master's degree ${ }^{2}$ & 21,048 & 9.6 & 15,217 & 10.7 & 1,893 & 7.0 & 2,395 & 17.5 & 1,385 & 4.1 \\
\hline Professional degree & 3,172 & 1.4 & 2,373 & 1.7 & 188 & 0.7 & 351 & 2.6 & 221 & 0.7 \\
\hline Doctorate degree & \begin{tabular}{l|l}
4,468 \\
\end{tabular} & 2.0 & 3,218 & 2.3 & 323 & 1.2 & 683 & 5.0 & 193 & 0.6 \\
\hline COLLEGE DEGREE OR HIGHER & 76,923 & 34.9 & 55,321 & 38.9 & 6,819 & 25.2 & \begin{tabular}{l|l}
7,726 \\
\end{tabular} & 56.5 & 6,213 & 18.4 \\
\hline
\end{tabular}

Source: United States Census Bureau, "Educational Attainment in the United States, 2018," Table 3.

Detailed Years of School Completed by People 25 Years and Over by Sex, Age Groups, Race and Hispanic Origin: 2018, February 21, 2019, at

https://www.census.gov/data/tables/2018/demo/education-attainment/cps-detailed-tables.html.

From their study, we have extracted the data most relevant for our purposes, displayed in Figure II.2 (recognizing, as we indicate below, that a more thorough analysis of the very rich database in the Brookings study can yield more refined results). The 53.2 million low-paid workers in the study represented 27.4 percent of the possible civilian labor force (the "universe population") and 43.7 percent of workers in the active labor force. The median annual income of low-wage workers was $\$ 17,953$, with many families having two or more income earners, as indicated by the median family earnings of $\$ 43,347$ for households of low-wage workers.

Whites were 62.6 percent of all workers, but 52.4 percent of low-wage workers. Nevertheless, more than half of all low-wage workers were white. Both Blacks and Hispanics were overrepresented among low-wage workers, at 14.8 percent and 24.9 percent of low-wage workers respectively.

By highest level of education completed, those workers with less than high school were 14.6 percent of all low-wage workers and only 4.4 percent of mid/high-wage workers. Workers whose high level of educational attainment was high school were 34.0 percent of low-wage workers and 20.2 percent percent of $\mathrm{mid} / \mathrm{high}$-wage workers. That means that there were 13.8 million workers with high school as the highest level completed who managed to climb into the $\mathrm{mid} / \mathrm{high}$ wage category, or 37.3 percent of all workers in the high-school-completed category. But well over 60 percent of those with high-school diplomas had low-wage work. At the same time, of all low-wage workers, those with "some college" were 28.8 percent, or 15.3 million people. Hence there were 1.5 million more people with some college who had low-wage work than there were workers with only high school who had mid/high-wage work. 
Since there can be transitions of individuals in both directions between mid/high-wage work and low-wage work over the course of their working lives - with the possibility, for example, of younger people in the dataset moving up the wage scale by acquiring higher education later in their careers - we should expect that age (which is included as an observation in Brookings study) may be an important variable for discerning patterns of upward or downward wage mobility. Further insights into the relation between low-wage work and education can potentially be gleaned from the Brookings database through statistical analysis based on cross-tabulations of race, ethnicity, and age of workers by wage level and school-attainment level.

Table II.2: Low-paid work in the United States, 2012-2016, by gender/race/ethnicity and educational attainment

Status of workers

\begin{tabular}{|l|r|r|r|r|}
\hline & \multicolumn{1}{|c|}{$\begin{array}{c}\text { Weighted } \\
\text { population, } \\
\text { millions }\end{array}$} & $\begin{array}{c}\text { \%of universe } \\
\text { population }\end{array}$ & \% of workers & \% unemployed \\
\hline Universe population & 194.3 & 100.0 & 62.7 & 100.0 \\
\hline Workers & 121.8 & 35.3 & 56.3 & 3.6 \\
\hline Mid/high-wage workers & 68.5 & 27.4 & 43.7 & 2.4 \\
\hline Low-wage workers & 53.2 & 5.6 \\
\hline
\end{tabular}

Earnings

\begin{tabular}{|l|r|r|r|r|r|}
\hline & Median hourly & $\begin{array}{c}\text { Median } \\
\text { annual }\end{array}$ & Median family & $\begin{array}{c}\text { \% Below } \\
100 \% \mathrm{FPL}\end{array}$ & \multicolumn{1}{c|}{$\begin{array}{c}\text { \% Below } \\
200 \% \mathrm{FPL}\end{array}$} \\
\hline Universe population & & & $\$ 62,290$ & 15.3 & 31.8 \\
\hline Workers & $\$ 17.78$ & $\$ 34,760$ & $\$ 70,974$ & 7.8 & 23.0 \\
\hline Mid/high-wage workers & $\$ 26.65$ & $\$ 54,410$ & $\$ 92,420$ & 1.3 & 6.3 \\
\hline Low-wage workers & $\$ 10.22$ & $\$ 17,953$ & $\$ 43,347$ & 16.2 & 44.6 \\
\hline
\end{tabular}

Gender/race/ethnicity

\begin{tabular}{|l|r|r|r|r|r|r|}
\hline & \% Male & \% White & \% Black & \% Hispanic & \% Asian & \% Other \\
\hline Universe population & 49.1 & 62.1 & 12.3 & 17.0 & 5.9 & 2.6 \\
\hline Workers & 51.6 & 62.6 & 12.0 & 17.3 & 5.6 & 2.4 \\
\hline Mid/high-wage workers & 55.8 & 70.6 & 9.9 & 11.4 & 6.0 & 2.1 \\
\hline Low-wage workers & 46.3 & 52.4 & 14.8 & 24.9 & 5.1 & 2.8 \\
\hline
\end{tabular}

Percent with highest-level of education completed

\begin{tabular}{|l|r|r|r|r|r|}
\hline & $\begin{array}{c}\text { Less than high } \\
\text { school }\end{array}$ & High school & Some college & $\begin{array}{c}\text { Associate } \\
\text { degree }\end{array}$ & $\begin{array}{c}\text { Bachelor's or } \\
\text { higher }\end{array}$ \\
\hline Universe population & 11.8 & 26.6 & 24.5 & 8.4 & 28.7 \\
\hline Workers & 8.9 & 26.2 & 24.3 & 9.5 & 31.1 \\
\hline Mid/high-wage workers & 4.4 & 20.2 & 20.9 & 10.4 & 44.1 \\
\hline Low-wage workers & 14.6 & 34.0 & 28.8 & 8.3 & 14.3 \\
\hline
\end{tabular}

Source: Ross and Bateman, "Meet the Low-Wage Workforce," data appendix.

Note: FPL=federal poverty line 


\section{The importance of good jobs}

Nothing speaks to the importance of sustained access to good jobs for African Americans more than their horrific experience in the Covid-19 pandemic. There are ample data showing that Blacks and Hispanics have contracted Covid-19 and died from it at a much higher rates than have other groups. ${ }^{16}$ The discussion of factors explaining the racial/ethnic gap in morbidity and mortality from Covid-19 all point to the need for better employment opportunities for Black and Hispanic Americans. All the usual suspects - relatively worse health conditions, less access to healthcare, poorer housing quality with higher population density, jobs that pose heightened risk of catching Covid-19, as well as a greater likelihood of layoff and unemployment-are consequences of persistent economic disadvantage. The only long-term remedy is a vast expansion of opportunity for stable, well-paid employment. In this paper, we look at the distribution of jobs held by Blacks versus other groups and at a host of adverse economic impacts that lower access to good jobs has wrought.

Well-paid employment over a period of decades is a necessary condition for belonging to the middle class. A family needs good earnings over decades not only to survive but also to enable it to invest in the capabilities of its members so that they can become productive and well-paid participants in the labor force. A broad middle class supports a tax system that can fund government investment in infrastructure and knowledge, which in turn provides essential collective support for households to invest in the productive capabilities of their members.

In 1965, the creation of the Equal Employment Opportunity Commission (EEOC) sought, among other things, to ensure that Blacks in the U.S. labor force would eventually overcome the legacies of inferior education and job discrimination to become equal with whites in accessing well-paid and stable employment opportunities. What has happened since then? In this, the second working paper of our "Fifty Years After" project, we provide a statistical overview of the employment and earnings progress of Blacks in comparison with whites since the mid-1960s. How have the occupations and industries in which Blacks have worked as well as the earnings which they have received in those jobs stacked up in comparison with whites and other groups? How have these patterns changed over the last five decades? What progress, if any, has been made in the last decade since the Great Recession?

Lagging educational credentials are frequently offered as one explanation for relatively low earnings and higher unemployment among Blacks compared with whites. Following our comparative analysis of jobs and earnings, we document the current distributions of educational attainment for African Americans and other groups as well as the education trends going back to

\footnotetext{
${ }^{16}$ Yaryna Serkez, "Who Is most likely to die from the coronavirus?" New York Times, June 4, 2020, at https://www.nytimes.com/interactive/2020/06/04/opinion/coronavirus-health-raceinequality.html?referringSource=articleSharel=; Tiffany Ford, Sarah Reber, and Richard V. Reeves, "Race gaps in COVID-19 deaths are even bigger than they appear," Brookings, June 16, 2020, at https://www.brookings.edu/blog/upfront/2020/06/16/race-gaps-in-Covid-19-deaths-are-even-bigger-than-they-appear/; Richard A. Oppel, Jr., Robert Gebeloff, K. K. Rebecca Lai, Will Wright, and Rich Smith, "The fullest look yet at the racial inequity of coronavirus," New York Times, July 5, 2020, at https://www.nytimes.com/interactive/2020/07/05/us/coronavirus-latinos-african-americans-cdc-data.html
} 
the beginning of the 1970s. We then look at the differences in Black and white unemployment and wage rates, with and without accounting for differences in education.

Educational attainment matters, but it is not the full explanation for the differences in employment opportunity. Lack of educational attainment can exclude a person from gaining access to entrylevel positions in government, business, and civil-society organizations at certain hierarchical levels and functional specialties. Professional and advanced degrees in specialized fields are qualifications for accessing more rewarding occupations. But even in jobs requiring only highschool educations, critical determinants of one's earnings over the decades that constitute one's working life are non-discriminatory access to both entry-level positions and, then, in-house (or internal) job ladders to which the entry-level positions provide access. Movement up these internal job ladders enables employees to gain the work experience that adds to their productivity and can enable them to earn steady, and typically rising, incomes over years and even decades.

Stable jobs that enable workers to share in productivity gains and hence increase their real earnings over time facilitate the accumulation of wealth. In its various forms, wealth influences the current and future well-being of families and their children by enabling investments in education and training, providing savings to cope with unforeseen circumstances, and funding retirement. We examine data on the position of African Americans relative to others in the accumulation of wealth overall and within separate categories of wealth, including housing equity, housing stability measured by delinquency on mortgages and foreclosure, retirement savings and liquid savings, corporate shareholding, and student-loan debt. We also look at health insurance coverage, because it functions, in part, like savings that can be called upon to deal with unanticipated events. And lack of health insurance can wipe out one's accumulated wealth should one require hospitalization and/or expensive drugs.

Although manifest progress has been made by a portion of better educated Blacks, the overall picture for wealth accumulation for Blacks in comparison with whites is grim. The stark message is that for all these indicators, on average, African Americans consistently rank last, or next to last, when compared with their white, Hispanic, and Asian counterparts. There are substantial wealth gaps between Blacks and whites and in most cases the gaps are growing. Each of these indicators in some way is related to the jobs that African Americans hold and the wages they get paid, and hence their earnings, security and career advancement, compared with jobs that whites hold. Black-white disparities in these indicators are largely, although not entirely, generated by Blackwhite disparities in jobs and associated earnings levels and career paths over time.

\section{Jobs and earnings}

As we make clear below, along all dimensions of economic well-being that are dependent on access to jobs that are well-paid and stable, Blacks do worse than whites. In most cases, the relative disadvantage has grown worse over the last several decades, and even more so during and after the Great Recession. The data we present are the most recent available.

Tables II.3 and II.4 show the recent distribution of jobs by race and ethnicity by major occupational (for 2019) and industry (for 2018) categories. Table II.5 gives the usual weekly earnings by occupational categories by race and ethnicity (the list of occupational categories is slightly more 
detailed in this table than in Table II.3). For each occupational category, we show the ratios of earnings of Black men and Black women to the earnings of white men. It should be noted that, as of July 2019, whites who were not Hispanic or Latino were 60.1 percent of the population, Hispanics or Latinos 18.5 percent, Blacks 13.4 percent, and Asians 5.9 percent. ${ }^{17}$

Looking first at major occupational categories, compared to their percent of total employment, Blacks are overrepresented in service occupations as well as in production, transportation, and material moving occupations, and to a lesser degree in sales and office occupations. Black men are overrepresented in production, transportation, and material moving occupations, and installation, maintenance and repair occupations. Black women are overrepresented in service, and, within the broader category of sales and office occupations, office and administrative support occupations. Hispanic men and women are also overrepresented in the same categories, although Hispanic women are also overrepresented in production jobs. The striking areas of overrepresentation for Hispanics, and for Hispanic men in particular, are in farming and construction jobs.

The data on earnings for Blacks in these jobs compared with white men, as well as the representation of Blacks in more detailed occupational categories, shed light on what overrepresentation in these broad occupational categories implies for the well-being of Black workers. Blacks are overrepresented in many low-paid occupations (see the earnings data in Table II.5).

Within the industry categories shown in Table II.4, Blacks are particularly overrepresented in transportation and utilities as well as education and health services, which accords with the data on occupations. Blacks comprise 12.3 percent of all jobs; Black men 5.8 percent and Black women 6.3 percent. Blacks hold 19.2 percent of transportation and utilities jobs and 15.1 percent of education and health services jobs. Black men are 13.9 percent of transportation, while Black women are 11.6 percent of education and health services. It is likely that the jobs in transportation which Blacks hold are disproportionately in urban mass transit systems. ${ }^{18}$ Blacks are modestly overrepresented in the leisure and hospitality industry and in retail trade, both of which typically provide low earnings. In manufacturing, Black men are somewhat above proportional representation, although they are particularly well-represented within the generally lower-paid subcategory of non-durable manufacturing.

\footnotetext{
${ }^{17}$ United States Census Bureau, "Quick Facts: Population estimates, July 1, 2019,” at https://www .census.gov/quickfacts/fact/table/US/PST045219.

${ }^{18}$ See Philip W. Jeffress. The Negro in the Urban Transit Industry. Philadelphia: Industrial Research Unit, Dept. of Industry, Wharton School of Finance and Commerce, University of Pennsylvania; 1970; incorporated into Herbert Northrup et al., Negro Employment in Land and Air Transport; a Study of Racial Policies in the Railroad, Airline, Trucking, and Urban Transit Industries, Philadelphia: Industrial Research Unit, Wharton School of Finance and Commerce, University of Pennsylvania, 1971. See also Beverly G. Ward and Eric T. Hill, "Women in Transit: Findings from African-Americans, Other Minorities, and Women in the Transit Industry," Women's Travel Issues, Proceedings From The Second National Conference, Chapter 32 October 1996: 581-629 at https://www.fhwa.dot.gov/ohim/womens/chap32.pdf.
} 


\section{Table II.3: Percent of employment in occupational categories by race, ethnicity, and gender, 2019}

\begin{tabular}{|c|c|c|c|c|c|c|c|c|c|c|c|c|c|c|c|}
\hline \multirow[b]{2}{*}{ Occupations } & \multicolumn{3}{|c|}{ All } & \multicolumn{3}{|c|}{ White } & \multicolumn{3}{|c|}{ Black } & \multicolumn{3}{|c|}{ Asian } & \multicolumn{3}{|c|}{ Hispanic } \\
\hline & $\mathbf{T}$ & M & $\mathbf{F}$ & $\mathbf{T}$ & M & $\mathbf{F}$ & $\mathbf{T}$ & M & $\mathbf{F}$ & $\mathbf{T}$ & M & $\mathbf{F}$ & $\mathbf{T}$ & M & $\mathbf{F}$ \\
\hline \multirow[t]{2}{*}{ Employees (thousands), 16 years and older } & 157,538 & 83,460 & 74,078 & 122,441 & 66,100 & 56,341 & 19,381 & 9,145 & 10,236 & 10,179 & 5,353 & 4,826 & 27,805 & 15,782 & 12,023 \\
\hline & \multicolumn{15}{|c|}{ Percent of total employed in occupational category } \\
\hline All occupations & 100.0 & 53.0 & 47.0 & 77.7 & 42.0 & 35.8 & 12.3 & 5.8 & 6.5 & 6.5 & 3.4 & 3.1 & 17.6 & 10.0 & 7.6 \\
\hline Management, professional, and related & 40.8 & 48.2 & 51.7 & 78.9 & 38.6 & 40.4 & 9.6 & 3.7 & 5.9 & 8.7 & 4.7 & 4.0 & 10.1 & 4.8 & 5.3 \\
\hline Management, business, and financial operations & 17.1 & 56.1 & 44.3 & 82.3 & 47.1 & 34.9 & 8.4 & 3.7 & 4.7 & 7.0 & 3.7 & 3.3 & 10.4 & 5.8 & 4.6 \\
\hline Professional and related & 23.6 & 42.7 & 57.4 & 76.7 & 32.4 & 44.4 & 10.5 & 3.7 & 6.9 & 10.0 & 5.5 & 4.5 & 9.9 & 4.0 & 5.9 \\
\hline Service & 17.1 & 42.4 & 57.7 & 72.3 & 31.4 & 40.8 & 17.1 & 6.7 & 10.5 & 6.0 & 2.3 & 3.6 & 25.0 & 11.1 & 13.9 \\
\hline Sales and office & 21.2 & 39.5 & 60.6 & 78.1 & 31.1 & 47.1 & 12.9 & 4.8 & 8.2 & 5.2 & 2.3 & 2.9 & 17.2 & 6.8 & 10.3 \\
\hline Sales and related & 9.9 & 51.4 & 48.9 & 80.1 & 42.0 & 37.6 & 11.2 & 4.7 & 6.4 & 5.4 & 2.9 & 2.4 & 16.8 & 8.0 & 8.7 \\
\hline Office and administrative support & 11.3 & 29.1 & 70.7 & 76.3 & 21.2 & 55.4 & 14.5 & 4.7 & 9.8 & 5.0 & 1.7 & 3.3 & 17.5 & 5.8 & 11.8 \\
\hline Natural resources, construction, and maintenance & 9.1 & 94.9 & 5.2 & 86.3 & 81.6 & 4.7 & 7.7 & 7.2 & 0.5 & 2.2 & 2.1 & 0.1 & 31.8 & 29.9 & 1.9 \\
\hline Farming, fishing, and forestry & 0.7 & 75.7 & 26.9 & 88.8 & 71.9 & 25.5 & 5.3 & 3.3 & 1.9 & 1.8 & 1.5 & 0.4 & 50.4 & 35.8 & 14.2 \\
\hline Construction and extraction & 5.3 & 96.0 & 3.5 & 86.5 & 83.9 & 2.7 & 7.2 & 7.0 & 0.2 & 1.6 & 1.5 & 0.1 & 36.3 & 35.2 & 1.2 \\
\hline Installation, maintenance, and repair & 3.1 & 95.7 & 4.6 & 82.7 & 81.2 & 3.5 & 9.1 & 8.4 & 0.6 & 3.3 & 3.2 & 0.1 & 20.5 & 19.4 & 0.7 \\
\hline Production, transportation, and material moving & 11.8 & 77.2 & 23.1 & 74.4 & 58.3 & 16.1 & 16.9 & 12.7 & 4.2 & 5.0 & 3.4 & 1.6 & 23.0 & 17.1 & 6.0 \\
\hline Production & 5.4 & 71.6 & 28.7 & 77.7 & 56.7 & 20.5 & 13.4 & 8.9 & 4.5 & 6.1 & 3.5 & 2.6 & 23.2 & 15.4 & 7.9 \\
\hline Transportation and material moving & 6.4 & 81.9 & 18.4 & 71.6 & 59.7 & 12.9 & 20.0 & 15.9 & 4.1 & 4.0 & 3.3 & 0.7 & 22.9 & 18.5 & 4.4 \\
\hline
\end{tabular}

Source: Bureau of Labor Statistics, Report on labor force characteristics by race and ethnicity, 2019; based on the Current Population Survey Table 10. Employed people by occupation, gender, race, and Hispanic or Latino ethnicity, 2019 annual averages

Notes: $\mathrm{T}=$ total, $\mathrm{M}=$ male, $\mathrm{F}=$ female

\section{Table II.4: Percent of employment by industry categories by race, ethnicity, and gender, 2018}

\begin{tabular}{|c|c|c|c|c|c|c|c|c|c|c|c|c|c|c|c|}
\hline \multirow[b]{2}{*}{ Industries } & \multicolumn{3}{|c|}{ All } & \multicolumn{3}{|c|}{ White } & \multicolumn{3}{|c|}{ Black } & \multicolumn{3}{|c|}{ Asian } & \multicolumn{3}{|c|}{ Hispanic } \\
\hline & $\mathbf{T}$ & $\mathbf{M}$ & $\mathbf{F}$ & $\mathbf{T}$ & M & $\mathbf{F}$ & $\mathbf{T}$ & $\mathbf{M}$ & $\mathbf{F}$ & $\mathbf{T}$ & $\mathbf{M}$ & $\mathbf{F}$ & $\mathbf{T}$ & M & $\mathbf{F}$ \\
\hline \multirow[t]{2}{*}{ Employees, 16 years and older (thousands) } & 155,761 & 82,698 & 73,063 & 121,461 & 65,702 & 55,759 & 19,091 & 9,018 & 10,073 & 9,832 & 5,188 & 4,644 & 27,012 & 15,418 & 11,594 \\
\hline & \multicolumn{15}{|c|}{ Percent of total employment in industry category } \\
\hline All industries & 100.0 & 53.1 & 46.9 & 78.0 & 42.2 & 35.8 & 12.3 & 5.8 & 6.5 & 6.3 & 3.3 & 3.0 & 17.3 & 9.9 & 7.4 \\
\hline Agriculture, forestry, and fishing & 1.6 & 73.0 & 26.4 & 92.6 & 65.9 & 22.4 & 2.3 & 2.2 & 0.4 & 1.6 & 0.8 & 0.6 & 24.9 & 18.6 & 6.5 \\
\hline Mining & 0.5 & 84.9 & 9.4 & 93.6 & 75.9 & 14.3 & 7.4 & 4.6 & 1.3 & 2.5 & 2.0 & 0.6 & 20.8 & 17.8 & 3.0 \\
\hline Construction & 7.2 & 90.0 & 9.8 & 87.7 & 79.7 & 8.9 & 6.1 & 5.7 & 0.4 & 1.9 & 1.7 & 0.3 & 30.6 & 28.9 & 1.8 \\
\hline Manufacturing & 10 & 70.6 & 29.1 & 79.5 & 57.4 & 22.2 & 10.4 & 6.9 & 3.5 & 6.9 & 4.3 & 2.6 & 16.6 & 11.2 & 5.4 \\
\hline Durable goods & 6.3 & 75.0 & 25.3 & 80.5 & 61.6 & 19.3 & 9.3 & 6.4 & 2.9 & 7.5 & 5.1 & 2.4 & 14.3 & 10.5 & 3.8 \\
\hline Nondurable goods & 3.7 & 63.1 & 35.5 & 78.0 & 50.2 & 27.1 & 12.3 & 7.8 & 4.5 & 5.8 & 3.0 & 2.9 & 20.6 & 12.6 & 8.2 \\
\hline Wholesale and retail trade & 13 & 55.1 & 44.7 & 78.6 & 44.1 & 34.7 & 11.9 & 6.2 & 5.7 & 5.6 & 3.1 & 2.5 & 18.0 & 9.9 & 8.1 \\
\hline Wholesale trade & 2.4 & 70.8 & 27.4 & 81.2 & 59.8 & 22.4 & 8.7 & 6.3 & 2.7 & 5.0 & 3.2 & 1.9 & 18.8 & 12.8 & 5.9 \\
\hline Retail trade & 10.7 & 51.6 & 48.2 & 77.3 & 40.2 & 37.1 & 12.5 & 6.2 & 6.3 & 5.6 & 3.1 & 2.6 & 17.7 & 9.2 & 8.5 \\
\hline Transportation & 5.5 & 75.3 & 24.7 & 70.9 & 55.2 & 16.9 & 19.2 & 13.9 & 5.4 & 5.5 & 4.1 & 1.4 & 18.3 & 14.0 & 4.2 \\
\hline Information & 1.9 & 61.5 & 37.0 & 78.0 & 48.8 & 30.1 & 11.6 & 6.7 & 4.8 & 7.3 & 4.6 & 2.5 & 11.9 & 7.8 & 4.3 \\
\hline Financial activities & 6.8 & 47.6 & 53.1 & 80.3 & 38.5 & 41.6 & 10.3 & 4.3 & 5.9 & 7.5 & 3.9 & 3.6 & 12.8 & 6.0 & 6.8 \\
\hline Professional and business services & 12.2 & 58.3 & 41.5 & 78.0 & 45.6 & 32.3 & 9.8 & 5.3 & 4.6 & 9.0 & 5.6 & 3.3 & 15.9 & 9.2 & 6.7 \\
\hline Education and health services & 22.5 & 25.7 & 74.4 & 75.6 & 19.1 & 56.5 & 15.1 & 3.6 & 11.6 & 6.4 & 2.2 & 4.2 & 12.9 & 3.2 & 9.8 \\
\hline Leisure and hospitality & 9.2 & 48.5 & 51.5 & 73.7 & 35.3 & 38.5 & 13.3 & 6.5 & 6.8 & 6.8 & 3.6 & 3.2 & 23.0 & 11.5 & 11.5 \\
\hline Other services & 5 & 45.7 & 53.5 & 76.4 & 36.3 & 40.1 & 10.8 & 4.9 & 5.9 & 8.3 & 3.1 & 5.2 & 20.1 & 10.3 & 10.0 \\
\hline Other services, except private households & 4.5 & 50.7 & 49.0 & 76.2 & 40.3 & 36.6 & 10.9 & 5.4 & 5.6 & 9.0 & 3.4 & 5.6 & 17.7 & 11.0 & 6.6 \\
\hline Other services, private households & 0.5 & 10.6 & 93.8 & 78.0 & 8.4 & 78.8 & 9.8 & 0.0 & 9.1 & 2.5 & 0.7 & 2.4 & 45.1 & 2.0 & 40.2 \\
\hline Public administration & 4.8 & 54.2 & 45.0 & 74.7 & 43.1 & 31.3 & 16.9 & 7.1 & 9.7 & 4.3 & 2.2 & 2.2 & 11.6 & 6.2 & 5.6 \\
\hline
\end{tabular}

Source: Bureau of Labor Statistics Report 1082, Labor force characteristics by race and ethnicity, 2018; based on the Current Population Survey Table 9. Employed people by industry, gender, race, and Hispanic or Latino ethnicity, 2018 annual averages

Notes: $\mathrm{T}=$ total, $\mathrm{M}=$ male, $\mathrm{F}=$ female 
Table II.5: Median usual weekly earnings by occupation, race, ethnicity, and gender, 2018

\begin{tabular}{|c|c|c|c|c|c|c|c|c|c|c|c|c|c|c|c|}
\hline \multirow[b]{2}{*}{ Occupations } & \multicolumn{3}{|c|}{ White } & \multicolumn{4}{|c|}{ Black } & \multicolumn{4}{|c|}{ Asian } & \multicolumn{4}{|c|}{ Hispanic } \\
\hline & M & $\mathbf{F}$ & \%WM & M & \%WM & $\mathbf{F}$ & \%WM & M & \%wM & $\mathbf{F}$ & \%WM & M & \%WM & $\mathbf{F}$ & \%WM \\
\hline All occupations, employees 16 years and older & $\$ 1,002$ & $\$ 817$ & 82 & $\$ 735$ & 73 & $\$ 654$ & 65 & $\$ 1,241$ & 124 & $\$ 937$ & 94 & $\$ 720$ & 72 & $\$ 617$ & 62 \\
\hline Management, professional, and related & 1,488 & 1,087 & 73 & 1,164 & 78 & 918 & 62 & 1,732 & 116 & 1,317 & 89 & 1,174 & 79 & 915 & 61 \\
\hline Management & 1,623 & 1,246 & 77 & 1,201 & 74 & 1,072 & 66 & 1,882 & 116 & 1,547 & 95 & 1,161 & 72 & 1,026 & 63 \\
\hline Business and financial operations & 1,421 & 1,101 & 77 & 1,219 & 86 & 1,019 & 72 & 1,506 & 106 & 1,255 & 88 & 1,202 & 85 & 944 & 66 \\
\hline Computer and mathematical & 1,575 & 1,243 & 79 & 1,234 & 78 & 1,209 & 77 & 1,840 & 117 & 1,633 & 104 & 1,326 & 84 & 1,152 & 73 \\
\hline Architecture and engineering & 1,520 & 1,248 & 82 & 1,346 & 89 & 1,343 & 88 & 1,768 & 116 & 1,329 & 87 & 1,442 & 95 & 1,060 & 70 \\
\hline Life, physical, and social science & 1,366 & 1,172 & 86 & 1,223 & 90 & 965 & 71 & 1,372 & 100 & 1,193 & 87 & 1,337 & 98 & 861 & 63 \\
\hline Community and social services & 1,035 & 905 & 87 & 856 & 83 & 834 & 81 & 1,014 & 98 & 935 & 90 & 969 & 94 & 830 & 80 \\
\hline Legal & 1,929 & 1,234 & 64 & 1,730 & 90 & 1,073 & 56 & 1,772 & 92 & 1,468 & 76 & 1,442 & 75 & 1,088 & 56 \\
\hline Education, training, and library & 1,236 & 959 & 78 & 1,079 & 87 & 806 & 65 & 1,613 & 131 & 916 & 74 & 1,033 & 84 & 852 & 69 \\
\hline Arts, design, entertainment, sports, and media & 1,153 & 989 & 86 & 1,087 & 94 & 997 & 86 & 1,527 & 132 & 1,055 & 92 & 1,034 & 90 & 822 & 71 \\
\hline Healthcare practitioner and technical & 1,405 & 1,100 & 78 & 1,133 & 81 & 878 & 62 & 1,523 & 108 & 1,270 & 90 & 1,079 & 77 & 891 & 63 \\
\hline Service & 670 & 517 & 77 & 579 & 86 & 490 & 73 & 615 & 92 & 528 & 79 & 589 & 88 & 489 & 73 \\
\hline Healthcare support & 687 & 570 & 83 & 608 & 89 & 508 & 74 & 519 & 76 & 582 & 85 & 596 & 87 & 546 & 79 \\
\hline Protective service & 1,009 & 708 & 70 & 672 & 67 & 518 & 51 & 876 & 87 & 568 & 56 & 829 & 82 & 600 & 59 \\
\hline Food preparation and serving related & 546 & 472 & 86 & 481 & 88 & 448 & 82 & 577 & 106 & 512 & 94 & 560 & 103 & 450 & 82 \\
\hline Building and grounds cleaning and maintenance & 609 & 482 & 79 & 548 & 90 & 450 & 74 & 689 & 113 & 524 & 86 & 578 & 95 & 466 & 77 \\
\hline Personal care and service & 646 & 525 & 81 & 619 & 96 & 492 & 76 & 640 & 99 & 513 & 79 & 585 & 91 & 489 & 76 \\
\hline Sales and office & 895 & 710 & 79 & 657 & 73 & 631 & 71 & 892 & 100 & 731 & 82 & 687 & 77 & 624 & 70 \\
\hline Sales and related & 1,006 & 687 & 68 & 680 & 68 & 529 & 53 & 943 & 94 & 657 & 65 & 753 & 75 & 556 & 55 \\
\hline Office and administrative support & 760 & 716 & 94 & 638 & 84 & 675 & 89 & 841 & 111 & 758 & 100 & 640 & 84 & 657 & 86 \\
\hline Natural resources, construction, and maintenance & 851 & 618 & 73 & 750 & 88 & 892 & 105 & 892 & 105 & 606 & 71 & 699 & 82 & 506 & 59 \\
\hline Farming, fishing, and forestry & 608 & 481 & 79 & 423 & 70 & 597 & 98 & 488 & 80 & 466 & 77 & 574 & 94 & 467 & 77 \\
\hline Construction and extraction & 818 & 760 & 93 & 723 & 88 & 1,117 & 137 & 838 & 102 & 1,190 & 145 & 707 & 86 & 639 & 78 \\
\hline Installation, maintenance, and repair & 951 & 815 & 86 & 791 & 83 & 940 & 99 & 996 & 105 & 627 & 66 & 761 & 80 & 719 & 76 \\
\hline Production, transportation, and material moving & 790 & 563 & 71 & 643 & 81 & 539 & 68 & 752 & 95 & 587 & 74 & 670 & 85 & 499 & 63 \\
\hline Production & 822 & 581 & 71 & 617 & 75 & 531 & 65 & 788 & 96 & 601 & 73 & 690 & 84 & 504 & 61 \\
\hline Transportation and material moving & 749 & 533 & 71 & 664 & 89 & 560 & 75 & 710 & 95 & 539 & 72 & 654 & 87 & 491 & 66 \\
\hline
\end{tabular}

Source: Bureau of Labor Statistics, Report 1082, Labor force characteristics by race and ethnicity, 2018; based on the Current Population Survey Table 18. Median usual weekly earnings of full-time wage and salary workers by occupation, gender, race, and Hispanic or Latino ethnicity, 2018 annual averages

Notes: $\mathrm{M}=$ male; $\mathrm{F}=$ female; \%WM=percent of white men's earnings for that occupation.

Earnings of Black men are 83 percent and Black women 81 percent of white men's in community and social service occupations, an underpaid professional field that disproportionately employs Blacks. Earnings of Black men are also nearer those of white men in the very low-paid categories of healthcare support occupations, food preparation and serving related occupations, building and grounds cleaning and maintenance, personal care, and service occupations.

Compared with white men, Black women face a greater disparity than Black men in these and most other occupations, reflecting the combined disadvantage of being Black and female. Black women are poorly compensated in the high-paid legal occupation (receiving 56 percent of the pay of white men whereas Black men are paid 90 percent) and in the low-paid sales and related occupations (53 percent for Black women, 68 percent for Black men). Women are presumably overrepresented in the lower-paid jobs within these broader occupational categories.

Combining the information in Table II.3 and Table II.5, we see that, in general, the occupations in which Blacks are overrepresented are lower paying, though less so for the blue-collar (or industrial) occupations. This is true for Black men and for Black women. In the case of women, the blue-collar occupations are not, however, large sources of employment. 
A study by Darrick Hamilton, Algernon Austin, and William Darity for the Economic Policy Institute looks specifically at the relation between the representation of Black men in an occupation and the occupation's level of pay. They adjust the actual representation of Blacks in an occupation by the proportion of all Black men who have the educational attainment in the range that incumbent workers in that occupation actually have. ${ }^{19}$ They use American Community Survey data for 20052007; data from before the Great Recession and approximately a decade prior to the data in Table II.3 above. They find about the same overall ratio of Black men's earnings to white men's earnings (74 percent) as is found in Table II.5 and a very similar pattern of this ratio across occupational groups. They regress the level of pay across occupational subcategories on the education-adjusted degree of representation of Black men within the subcategory and find in all cases except construction statistically significant drops in pay as the representation of Black men in an occupation increases. This result reinforces the general finding that, within occupations, Black men are disproportionately found in the lower-paying job categories.

The earnings figures in Table II.5 are averages for all employees in the occupational category. There clearly is a wide variety of occupational levels averaged together within each category. Tables II.6 and II.7 provide more granular occupational data on earnings in those particular lines of work in which Blacks are most highly represented. These tables present the percent of Blacks in detailed occupational categories in professional and service jobs (Table II.6) and industrial jobs (Table II.7), with the occupations listed in order from those in which Blacks are most overrepresented. These tables reveal an easily interpretable pattern of earnings inequality because the categories with high representation of Blacks are low paid.

Table II.6 gives professional and service occupations ranked by the Black percent of employment, as well as some additional selected occupations with high Black representation. ${ }^{20}$ Table II.7 gives the same information for industrial occupations. ${ }^{21}$ With only a few exceptions, a scan down the percentage Black column in each table tells a troubling story. Although we do not report earnings for these occupations, the majority of these occupations are lower paid and some very low paid.

Among professional and service jobs, examples such as retail sales (12.4 percent) and food preparation (13.2 percent), personal care aides (21.1 percent), cooks (18.1 percent), cashiers (17.9 percent), and childcare (17.4 percent) are quite low paid, most around $\$ 25,000$ per year or less, well below the median earnings overall of about $\$ 41,000 .^{22}$ They also account for a relatively large amount of employment within this list of jobs. All but cashiers are projected to grow at least as fast as or faster than the average in the future, ${ }^{23}$ and all but cashiers and childcare are among the occupations with the largest projected employment growth. ${ }^{24}$ Within the medical field, other than

19 Darrick Hamilton, Algernon Austin and William Darity, Jr., "Whiter Jobs, Higher Wages: Occupational Segregation and the Lower Wages of Black Men," Economic Policy Institute Briefing Paper 288, February 2011, at https://www.epi.org/publication/whiter jobs higher wages/.

20 The employment by detailed occupation data are broken down only by race and ethnicity and not by gender.

21 Some occupations in the professional and service table are jobs in food preparation that bear a resemblance to industrial jobs. They are not, however, the kind of mass-production blue-collar jobs in capital-intensive industries that we discuss in the rest of our book that historically paid good wages and often were often represented by unions. Fast food workers, cooks and food preparation workers are in general, low paid and not unionized.

22 We took the median earnings for these example occupations from the Bureau of Labor Statistics, Occupational Outlook Handbook, http://www.bls.gov/ooh/home.htm.

23 Ibid.

24 Employment Projections, Bureau of Labor Statistics: Table 6, Occupations with the most job growth, 2014-24, https://www.bls.gov/news.release/ecopro.t06.htm 
the lowest paid jobs such as home health aides, personal care aides, and nurses assistants, are the allied health jobs just above those in pay such as phlebotomists ( 24.6 percent) and medical and health services managers (12.7 percent). Licensed practical nurses, of which 27.0 percent are Black women, are paid higher (around $\$ 43,000$ ) but are the lowest category of nurse above a nursing assistant. Further down the list and not shown in Table II.6, Blacks have attained lower levels of representation in higher-paid management jobs, such as financial managers (7.2 percent of all employees in the category), computer and information systems managers (5.6 percent), and chief executives where they are rarely seen (3.6 percent).

\section{Table II.6: Detailed professional and service occupations with high representation of Blacks, 2019}

\begin{tabular}{|c|c|c|c|c|c|}
\hline \multirow[t]{2}{*}{ Occupation } & \multirow{2}{*}{$\begin{array}{c}\text { Total } \\
\text { employed } \\
\text { (000s) }\end{array}$} & \multicolumn{4}{|c|}{ Percent of total employed } \\
\hline & & White & Black & Asian & Hispanic \\
\hline Total employees (thousands), 16 years and older & 157,538 & 77.7 & 12.3 & 6.5 & 17.6 \\
\hline Nursing, psychiatric, and home health aides & 2,086 & 54.3 & 37.2 & 4.4 & 17.6 \\
\hline Postal service clerks & 96 & 47.4 & 35.8 & 13.0 & 6.7 \\
\hline Bailiffs, correctional officers, and jailers & 372 & 60.5 & 34.2 & 1.7 & 12.3 \\
\hline Bill and account collectors & 116 & 63.6 & 30.2 & 1.3 & 17.8 \\
\hline Security guards and gaming surveillance officers & 937 & 62.9 & 29.6 & 3.5 & 18.8 \\
\hline Taxi drivers and chauffeurs & 790 & 55.5 & 29.5 & 13.1 & 23.6 \\
\hline Licensed practical and licensed vocational nurses & 687 & 67.0 & 27.0 & 3.3 & 13.8 \\
\hline Bus drivers & 546 & 67.2 & 27.0 & 3.1 & 15.0 \\
\hline Probation officers \& correctional treatment specialists & 97 & 70.6 & 26.7 & 0.4 & 15.8 \\
\hline Tax examiners and collectors, and revenue agents & 53 & 58.8 & 25.8 & 12.8 & 12.1 \\
\hline Miscellaneous healthcare support occupations & 206 & 64.7 & 25.7 & 7.1 & 13.7 \\
\hline Social and human service assistants & 238 & 65.2 & 25.5 & 4.3 & 16.4 \\
\hline Personal care aides & 1,458 & 60.2 & 25.1 & 8.4 & 21.6 \\
\hline Phlebotomists & 124 & 70.5 & 24.6 & 2.9 & 14.9 \\
\hline Social workers & 823 & 69.6 & 23.0 & 3.7 & 14.3 \\
\hline Eligibility interviewers, government programs & 70 & 70.1 & 22.2 & 1.1 & 23.0 \\
\hline Combined food preparation and serving workers & 372 & 70.2 & 19.6 & 5.4 & 19.9 \\
\hline Postal service mail carriers & 331 & 72.7 & 19.6 & 5.5 & 14.4 \\
\hline Food servers, nonrestaurant & 191 & 68.4 & 19.2 & 6.6 & 21.6 \\
\hline Cooks & 2,031 & 70.4 & 18.1 & 6.2 & 36.7 \\
\hline Cashiers & 3,164 & 69.2 & 17.9 & 7.3 & 24.1 \\
\hline Couriers and messengers & 402 & 73.3 & 17.4 & 4.4 & 21.4 \\
\hline Maids and housekeeping cleaners & 1,475 & 72.2 & 17.4 & 4.1 & 49.2 \\
\hline Childcare workers & 1,193 & 76.0 & 17.4 & 3.3 & 24.6 \\
\hline Preschool and kindergarten teachers & 655 & 75.8 & 15.7 & 5.2 & 14.9 \\
\hline Health practitioner support technologist/technicians & 710 & 74.7 & 15.6 & 5.4 & 16.5 \\
\hline Education administrators & 958 & 78.6 & 15.3 & 3.3 & 11.8 \\
\hline Human resources workers & 770 & 75.7 & 13.8 & 7.1 & 13.8 \\
\hline Food preparation workers & 1,079 & 73.5 & 13.2 & 8.3 & 28.1 \\
\hline Medical and health services managers & 677 & 79.0 & 12.7 & 5.7 & 11.8 \\
\hline Police and sheriff's patrol officers & 716 & 82.9 & 12.6 & 1.5 & 17.0 \\
\hline Retail salespersons & 3,105 & 78.9 & 12.4 & 4.5 & 18.7 \\
\hline Social and community service managers & 470 & 79.9 & 12.3 & 3.2 & 10.6 \\
\hline
\end{tabular}


Source: BLS Reports, Labor force characteristics by race and ethnicity, 2019; based on the Current Population Survey Table 11. Employed people by detailed occupation, race, and Hispanic or Latino ethnicity, 2019 annual averages.

Table II.7: Detailed industrial occupations with high representation of Black employees, 2019

\begin{tabular}{|c|c|c|c|c|c|}
\hline \multirow{2}{*}{ Occupation } & \multirow{2}{*}{$\begin{array}{c}\text { Total } \\
\text { employed } \\
(000 s)\end{array}$} & \multicolumn{4}{|c|}{ Percent of total employed } \\
\hline & & White & Black & Asian & Hispanic \\
\hline Total employees (thousands), 16 years and older & 157,538 & 77.7 & 12.3 & 6.5 & 17.6 \\
\hline Industrial truck and tractor operators & 571 & 69.0 & 25.8 & 1.7 & 31.4 \\
\hline Laundry and dry-cleaning workers & 134 & 55.9 & 25.1 & 12.2 & 37.9 \\
\hline Railroad conductors and yardmasters & 52 & 66.7 & 24.0 & 3.1 & 5.4 \\
\hline Packaging and filling machine operators and tenders & 262 & 68.8 & 20.4 & 6.3 & 37.3 \\
\hline Laborers and freight, stock, and material movers, hand & 2,235 & 72.4 & 19.8 & 2.7 & 23.1 \\
\hline Miscellaneous assemblers and fabricators & 1,001 & 67.0 & 19.7 & 9.6 & 21.7 \\
\hline Supervisors of transportation/material moving workers & 206 & 72.2 & 19.4 & 6.7 & 20.3 \\
\hline Parking lot attendants & 83 & 72.6 & 19.3 & 5.7 & 31.0 \\
\hline Packers and packagers, hand & 628 & 69.2 & 19.0 & 7.7 & 41.5 \\
\hline Refuse and recyclable material collectors & 99 & 74.0 & 18.2 & 3.6 & 29.7 \\
\hline Food processing workers, all other & 147 & 72.1 & 18.1 & 7.0 & 38.8 \\
\hline Driver/sales workers and truck drivers & 3,608 & 75.2 & 18.1 & 2.9 & 20.5 \\
\hline Machine setters, operators, and tenders, metal and plastic ${ }^{*}$ & 70 & 75.2 & 17.3 & 0.3 & 13.9 \\
\hline Butchers and other meat, poultry, \&fish processing workers & 297 & 71.2 & 17.1 & 6.2 & 37.3 \\
\hline Production workers, all other & 1,141 & 73.8 & 16.1 & 5.7 & 24.6 \\
\hline Metal workers and plastic workers, all other & 392 & 72.0 & 14.5 & 8.2 & 26.0 \\
\hline Bakers & 228 & 74.0 & 11.7 & 9.6 & 30.7 \\
\hline
\end{tabular}

Source: BLS Reports, Labor force characteristics by race and ethnicity, 2019; based on the Current

Population Survey Table 11. Employed people by detailed occupation, race, and Hispanic or Latino ethnicity, 2019 annual averages.

* Full occupational title is "Cutting, punching, and press machine setters, operators, and tenders, metal and plastic"

The same is true for the professional occupations in this list. Blacks are well represented among social workers (23.0 percent), most likely Black women in this case, who make about the same modest earnings as licensed practical nurses (27.0 percent). Social workers ( 23.0 percent) typically work in government and civil-society sectors. As we show at a number of points in this book, the government sector has always been more open to Blacks than the business sector, first at the federal level and then later at the state and local levels. In our list, Blacks are well represented among mail carriers and postal workers (19.6 percent), who have secure jobs and make above the median earnings in the United States. Further down are higher salary professional jobs (not shown in Table II.6) in which Blacks have less representation such as network and computer systems administrators (11.5 percent), and computer systems analysts (9.6 percent).

Two other occupations in the government sector have high Black representation and are worthy of note: bailiffs, correctional officers and jailers (34.2 percent) and probation officers and correctional (treatment) specialists (26.7 percent). As others have noted, and as we discuss in more detail elsewhere in our book, the alarming rise of incarceration of Black men, and increasingly of Black 
women, which has had very damaging effects on Blacks generally, including their employment prospects once released from prison, has generated a rise in jobs guarding and monitoring arrested and convicted prisoners. Blacks are not only vastly overrepresented in the prison population but also as prison guards. This table shows that police forces have also provided important job opportunities for Blacks.

Finally, while not the same as jobs connected to the criminal justice system, Blacks are well represented among other types of guard labor such as security guards and gaming surveillance officers (29.6 percent) as well as bill and account collectors (30.2 percent) and tax examiners and collectors (25.8 percent). The percentage Black in the overall category, Protective Services, under which these particular occupations in Table II.6 are included, is 20 percent. ${ }^{25}$ The irony is that in all of these types of occupations, African American employees are likely providing security against or enforcing financial obligations disproportionately on low-income fellow African Americans.

The industrial jobs with a high representation of Blacks shown in Table II.7 are almost all low paying. Only jobs as supervisors of transportation and material-moving workers (19.4 percent) and, with low employment numbers, railroad conductors and yardmasters ( 24.0 percent) pay above the median earnings, and then only by about $\$ 10,000$ to $\$ 15,000$ more. All of the other categories pay below the median earnings, usually $\$ 10,000$ to $\$ 15,000$ less. In the main, the industrial jobs in which significant numbers of Blacks currently work do not provide a middle-class standard of living. ${ }^{26}$ Danyelle Solomon, Connor Maxwell, and Abril Castro arrived at very similar results using wage estimates from the Bureau of Labor Statistics. ${ }^{27}$ The next two sections detail the historical evolution of these distributions of jobs.

\section{How much progress?}

This and our forthcoming Working Papers tell a detailed story of gains achieved and then lost in the unionized blue-collar jobs and earnings that African Americans experienced following the civil rights era and civil rights legislation. In this section, we look at the jobs held by Blacks during the 1960s and 1970s to give an initial account of their employment experience since the passage of the Civil Rights Act.

To compare the historical data with the present distribution, we look at a table of occupations prepared by Lloyd Hogan and Harry Harris showing the degree of representation of Blacks in

\footnotetext{
${ }^{25}$ BLS Reports, Labor force characteristics by race and ethnicity, 2018, https://www.bls.gov/opub/reports/race-andethnicity/2018/home.htm

${ }^{26}$ There is no official Census Bureau definition of a middle-class income. The Pew Research Center in their analyses of "The Shrinking Middle Class," uses the following definition: "'middle-income' Americans are defined as adults whose annual household income is two-thirds to double the national median, after incomes have been adjusted for household size." They also adjust income by the cost of living for the metropolitan area in which the household resides. For the nation as a whole, the middle-income range for a one-person household in 2014 was $\$ 24,000$ to $\$ 72,000$ and for a household of three, it was $\$ 42,000$ to $\$ 125,000$. See “America’s Shrinking Middle Class: A Close Look at Changes Within Metropolitan Areas”, Pew Research Center, May 11, 2016, at http://www.pewsocialtrends.org/2016/05/11/americas-shrinking-middle-class-a-close-look-atchanges-within-metropolitan-areas/.

${ }_{27}^{27}$ Danyelle Solomon, Connor Maxwell, and Abril Castro, "Systematic Inequality and Economic Opportunity," Center for American Progress, August 7, 2019, at https://www .americanprogress.org/issues/race/reports/2019/08/07/472910/systematicinequality-economic-opportunity/.
} 
$1970 .{ }^{28}$ We have reproduced the first page of their Table 7 as our Table II.8. This table speaks quite clearly for itself. Blacks dominated the very low-paid occupations at the top of the table. Blacks held a fair number of assembler jobs, which as we show in Working Paper \#3, included some middle-class jobs in the 1970s.

Similarly, Blacks held jobs as elementary school teachers, many of which, we assume, were in schools with large numbers of Black children. Hogan and Harris' Table 7 continues through 100 occupations. Lower in the table, we observe some modest representation in good paying, perhaps middle class, jobs such as registered nurses, high school teachers, police officers, and librarians (in the 6.5 to 7.8 percent range of representation). Smaller numbers appear in blue-collar jobs such as carpenters, machinists, foremen and plumbers (5.0 percent range), smaller still among foremen and electricians, (3.0 percent range), and Blacks are 2.0 percent of salaried managers, 1.3 percent of lawyers and judges, and 1.2 percent of engineers. Comparing 1970 with 2019, it is clear that substantial progress has been made for a portion of educated Blacks.

We further set the stage for the main focus of our book by looking at shifts of Black representation in broad occupational categories in the half century from 1960. Table II.9 has two panels. Each shows the distribution of African Americans across occupational groups, but the separate panels answer two different questions. The first shows, for each occupational category, the fraction of all workers in that category who are Black. This statistic provides the degree of penetration, or representation, of Blacks in each occupational group. The second panel shows for each occupation, the percent of all employed African Americans who are working in that particular occupation. This statistic shows concentration, or segregation, of Blacks into the different occupations.

Note that in 2003 the Census instituted a major change in occupational classifications, which meant that we had to "crosswalk" the classifications from 2000 to 2010 to attain comparable categories. In particular, in 2003 the Census got rid of the general occupational classifications "nonfarm laborers" and "farm laborers," including workers who would have been included in these categories in 2000 in more specific categories in 2010. As a result, in 2010 the nonfarm laborers classification disappears while the number of people in the farm laborers and supervisors category is dramatically reduced (representing only "supervisors").

While we can make only limited inferences from these broad categories, this table shows progress for Blacks out of traditional low-paid jobs, progress into white-collar jobs, and progress into bluecollar operative jobs in the 1960s and 1970s. Progress stalled and reversed, however, after 1980. Looking first at the upper categories of white-collar jobs, we see that in the 1960s, Blacks were rarely seen as managers. The situation was slightly better among professional and technical workers, but representation was still very low.

\footnotetext{
${ }^{28}$ Lloyd Hogan, and Harry Harris, "The Occupational-Industrial Structure of Black Employment in the United States", Review of Black Political Economy, 6, 1, 1974, pp. 21-23, Table 7. See Working Paper \#3 report for presentation of data in their Table 7 as well as further discussion of the Hogan and Harris findings.
} 
Table II.8: Ranking of selected occupations by the Black employment share of each occupation, United States, 1970

\begin{tabular}{|c|c|c|c|c|}
\hline Rank & Occupation & $\begin{array}{c}\text { Blacks } \\
\text { employed } \\
\text { (000s) }\end{array}$ & $\begin{array}{l}\text { Blacks as } \\
\text { percent of } \\
\text { occupation }\end{array}$ & $\begin{array}{c}\text { Occupation as } \\
\text { percent of } \\
\text { all black } \\
\text { employment }\end{array}$ \\
\hline 1. & Private household worker & 613.0 & 52.0 & 8.3 \\
\hline 2 & Maid and cleaner & 239.9 & 37.6 & 3.2 \\
\hline 3 & Laundry and drycleaning operative & 113.7 & 32.4 & 1.5 \\
\hline 4 & Cement and concrete finisher & 21.6 & 31.4 & 0.3 \\
\hline 5 & Hospital attendant & 183.4 & 25.3 & 2.5 \\
\hline 6 & Janitor and sexton & 273.7 & 22.5 & 3.7 \\
\hline 7 & Postal clerk & 64.9 & 22.1 & 0.9 \\
\hline 8 & Nurse, practical & 51.1 & 21.7 & 0.7 \\
\hline 9 & Driver, taxi & 33.3 & 21.6 & 0.4 \\
\hline 10 & Laborer, except farm & 688.2 & 20.1 & 9.3 \\
\hline 11 & Laborer, farm & 150.7 & 20.1 & 2.0 \\
\hline 12 & Cook & 159.6 & 19.2 & 2.2 \\
\hline 13 & Social and recreation worker & 41.1 & 15.3 & 0.6 \\
\hline 14 & Brickmason and tile setter & 29.2 & 14.9 & 0.4 \\
\hline 15 & Painting, construction, and maintenance (operative) & 16.6 & 14.3 & 0.2 \\
\hline 16 & Packer and wrapper & 71.7 & 14.0 & 1.0 \\
\hline 17 & Driver, bus & 33.3 & 13.9 & 0.4 \\
\hline 18 & Craneman, derrick operator & 21.1 & 13.7 & 0.3 \\
\hline 19 & Driver, truck & 186.2 & 13.4 & 2.5 \\
\hline 20 & Shipping clerk & 54.8 & 13.3 & 0.7 \\
\hline 21 & File clerk & 44.5 & 12.2 & 0.6 \\
\hline 22 & Assembler & 113.9 & 12.1 & 1.5 \\
\hline 23 & Baker & 13.1 & 12.0 & 0.2 \\
\hline 24 & Roofer and slater & 6.9 & 11.9 & 0.1 \\
\hline 25 & Mail carrier & 29.6 & 11.7 & 0.4 \\
\hline 26 & Stock clerk and store keeper & 50.7 & 11.2 & 0.7 \\
\hline 27 & Telephone operator & 43.5 & 10.4 & 0.6 \\
\hline 28 & Guard and watchman & 33.4 & 10.4 & 0.5 \\
\hline 29 & Office machine operator & 57.0 & 10.1 & 0.8 \\
\hline 30 & Sewer and stitcher & 85.1 & 9.8 & 1.1 \\
\hline 31 & Barber & 16.7 & 9.8 & 0.2 \\
\hline 32 & Typist & 94.0 & 9.6 & 1.3 \\
\hline 33 & Deliveryman and routeman & 57.9 & 9.5 & 0.8 \\
\hline 34 & Teacher, elementry & 134.6 & 9.4 & 1.8 \\
\hline 35 & Mechanic, automobile & 76.4 & 9.4 & 1.0 \\
\hline 36 & Painter, construction, and maintenance (craftsman) & 29.9 & 9.0 & 0.4 \\
\hline 37 & Welder & 47.9 & 8.8 & 0.6 \\
\hline 38 & Funeral director and embalmer & 3.4 & 8.5 & 0.0 \\
\hline \multirow[t]{3}{*}{39} & Checker, examiner, and inspector (manufacturing) & 55.0 & 7.9 & 0.7 \\
\hline & TOTAL 39 OCCUPATIONS & $4,040.6$ & 17.5 & 54.6 \\
\hline & TOTAL ALL OCCUPATIONS & $7,403.1$ & 9.6 & 100.0 \\
\hline
\end{tabular}

Source: Hogan and Harris, "The Occupational-Industrial Structure,” Table 7. 
From the 1960s to the 1980s, Blacks made a very significant move into professional and technical jobs in representation and in the fraction of all Black employment. This progress may have been due to the substantial growth of the government sector at all levels in this period as well as affirmative action pressure on larger white-collar employers. ${ }^{29}$ The progress reversed in the 1980s, but then grew once again after 1990. In management, there also was progress starting in the 1960s and 1970s, although more modest than for professional jobs. Slow growth of Blacks in these jobs continued in the 1990s but accelerated thereafter. The same historical pattern is true in the main for sales and clerical jobs.

Table II.9 Black employment by occupation, 1960-2010

\begin{tabular}{|c|c|c|c|c|c|c|}
\hline 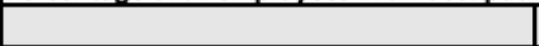 & 1960 & 1970 & 1980 & 1989 & 2000 & 2010 \\
\hline Blacks as $\%$ of all employees & 10.53 & 10.74 & 11.20 & 9.27 & 10.16 & 9.43 \\
\hline Professional and technical workers & 4.46 & 6.89 & 8.85 & 7.15 & 9.13 & 9.20 \\
\hline Managers and administrators except farm & 2.55 & 3.56 & 5.18 & 5.70 & 7.60 & 8.12 \\
\hline Sales workers & 2.46 & 3.63 & 5.10 & 6.40 & 8.80 & 9.80 \\
\hline Clerical workers & 5.19 & 8.11 & 11.09 & 11.40 & 13.70 & 12.50 \\
\hline Craft and kindred workers & 4.87 & 6.81 & 8.34 & 7.90 & 8.00 & 6.79 \\
\hline Operatives (including transport) & 11.83 & 14.37 & 15.34 & 14.60 & 15.48 & 13.93 \\
\hline Nonfarm laborers & 26.82 & 23.21 & 16.83 & 16.40 & 15.30 & NA \\
\hline Private household workers & 49.58 & 41.61 & 33.52 & 25.10 & 14.90 & 18.21 \\
\hline Service workers, except private household & 20.08 & 18.98 & 18.17 & 17.15 & 18.22 & 14.80 \\
\hline Farmers and farm managers & 8.05 & 4.77 & 2.18 & 0.80 & 0.90 & 0.60 \\
\hline Farm laborers and supervisors & 26.10 & 17.90 & 13.61 & 9.20 & 7.10 & 0.60 \\
\hline \multicolumn{7}{|c|}{ Percentage of all black employees in an occupational category } \\
\hline & 1960 & 1970 & 1980 & 1989 & 2000 & 2010 \\
\hline Total number of black employees (thousands & 6,927 & 8,445 & 10,890 & 11,969 & 15,279 & 15,019 \\
\hline Professional and technical workers & 4.79 & 9.10 & 12.70 & 11.48 & 15.20 & 19.14 \\
\hline Managers and administrators except farm & 2.59 & 3.50 & 5.20 & 7.08 & 9.81 & 14.21 \\
\hline Sales workers & 1.50 & 2.10 & 2.90 & 7.53 & 9.39 & 10.18 \\
\hline Clerical workers & 7.29 & 13.20 & 18.40 & 17.56 & 16.75 & 15.23 \\
\hline Craft and kindred workers & 5.99 & 8.20 & 9.60 & 9.13 & 7.77 & 5.54 \\
\hline Operatives (including transport) & 20.36 & 23.70 & 19.40 & 16.04 & 13.01 & 15.22 \\
\hline Nonfarm laborers & 13.67 & 10.30 & 6.90 & 6.70 & 5.44 & NA \\
\hline Private household workers & 14.17 & 7.70 & 3.20 & 1.83 & 0.77 & 4.46 \\
\hline Service workers, except private household & 17.47 & 18.30 & 19.90 & 21.06 & 20.80 & 15.97 \\
\hline Farmers and farm managers & 3.19 & 1.00 & 0.30 & 0.08 & 0.07 & 0.01 \\
\hline Farm laborers and supervisors & 8.98 & 2.90 & 1.50 & 1.52 & 0.98 & 0.03 \\
\hline
\end{tabular}

Source: United States Census Bureau, Statistical Abstract of the United States, various years, at https://www.census.gov/library/publications/time-series/statistical_abstracts.html.

Note: $\mathrm{NA}=$ not applicable. The Census occupational codes were changed substantially in 2003 . The percentages for 2010 involve an effort to cross walk the 2010 occupational categories to the pre2003 categories. For 2010, nonfarm laborers could not be matched to a pre-2003 occupational code.

\footnotetext{
${ }^{29}$ We discuss these changes further in Working Paper \#3.
} 
At the bottom of the pay hierarchy, Blacks made a significant move out of the low-paid household service and laborer jobs they held in large numbers in the 1960s, presumably having been replaced by Hispanic immigrants who were recruited after the 1960 s to take these jobs. ${ }^{30}$ In the case of household work, Black employment has been a disappearing act.

The movement out of their traditional low-paid occupations and the significant increases in whitecollar and service jobs suggest progress; and there certainly has been important progress for some better educated Blacks who have moved into middle and higher levels of management, administrative, professional and technical jobs. Remember, however, that Tables II.6 and II.7 of detailed occupations in which Blacks have high representation demonstrably show that Blacks have not moved in larger numbers into the better paying categories within any of these occupational groups. The only exception is management and professional jobs in the government and civil-society sectors, where pay is typically lower than in these job categories in the business sector. The pattern in the operatives' category, which is the closest category to the type of production jobs we focus on in the rest of our book, reflects the analysis we develop of these jobs. Black employment representation and numbers increased significantly in the 1960s. The representation moves up and down by small amounts after 1970, but the fraction of Blacks employed as operatives started its steady and substantial decline after the 1970s as Working Paper \#4 documents.

\section{The government sector}

In our discussion of the occupation and industry tables above, we noted the important role in employment opportunity for African Americans played by the government sector. We explore the history of Black employment in the government sector in Working Paper \#3 and its importance during the Civil rights period and into the 1970s. In Working Paper \#4, we analyze changes in employment in the government sector since the 1980s. In this section, we give a brief visual demonstration of the role that the government sector has played for African Americans over the period we are studying. We present two charts that show the greater access that the government sector provided to Blacks compared with the business sector. We see that employment of African Americans in the government sector peaked in the late 1970s fell in the 1980s, grew somewhat in the 1990s, and fell after that.

Figure II.3 comes from a study by David Cooper, Mary Gable, and Algernon Austin for the Economic Policy Institute. Their paper focuses on employment of African Americans in the state and local government sector. ${ }^{31}$ In Figure II.3, the African American share of employment in state and local government is much higher than it is in the business sector. Although the Black share of business-sector employment has declined modestly overall since 1999, the Black share of state and local government employment has declined much more, from the peak of 15.1 percent in 1999

\footnotetext{
${ }^{30}$ The specific change that allowed the increased immigration of Hispanics was the Immigration and Nationality Act of 1965 , passed soon after the Civil Rights Act of 1964. This act abolished the national quota system, known as the National Origins Formula, which had been instituted in 1921 as part of the Emergency Quota Act and further defined under the Immigration Act of 1924. Michael Piore analyzes how Hispanics were recruited in the 1960s to replace African Americans in many low-paid jobs, especially in agriculture and construction. Michael J. Piore, Birds of Passage: Migrant Labor and Industrial Societies, Oxford University Press, 1980.

${ }^{31}$ David Cooper, Mary Gable, and Algernon Austin "The Public-Sector Jobs Crisis: Women and African Americans Hit Hardest by Job Losses in State and Local Governments,” Economic Policy Institute Briefing Paper \#339, May 2012: Figure B, at https://www .epi.org/publication/bp339-public-sector-jobs-crisis/.
} 
to 12.8 percent in 2011. To amplify the importance of state and local government jobs to African Americans, not only in the number of jobs, the authors present evidence that Blacks have a smaller wage disparity with similarly educated and experienced white workers in the state and local government sector.

Figure II.3: African American share of employment by sector, 1980-2011

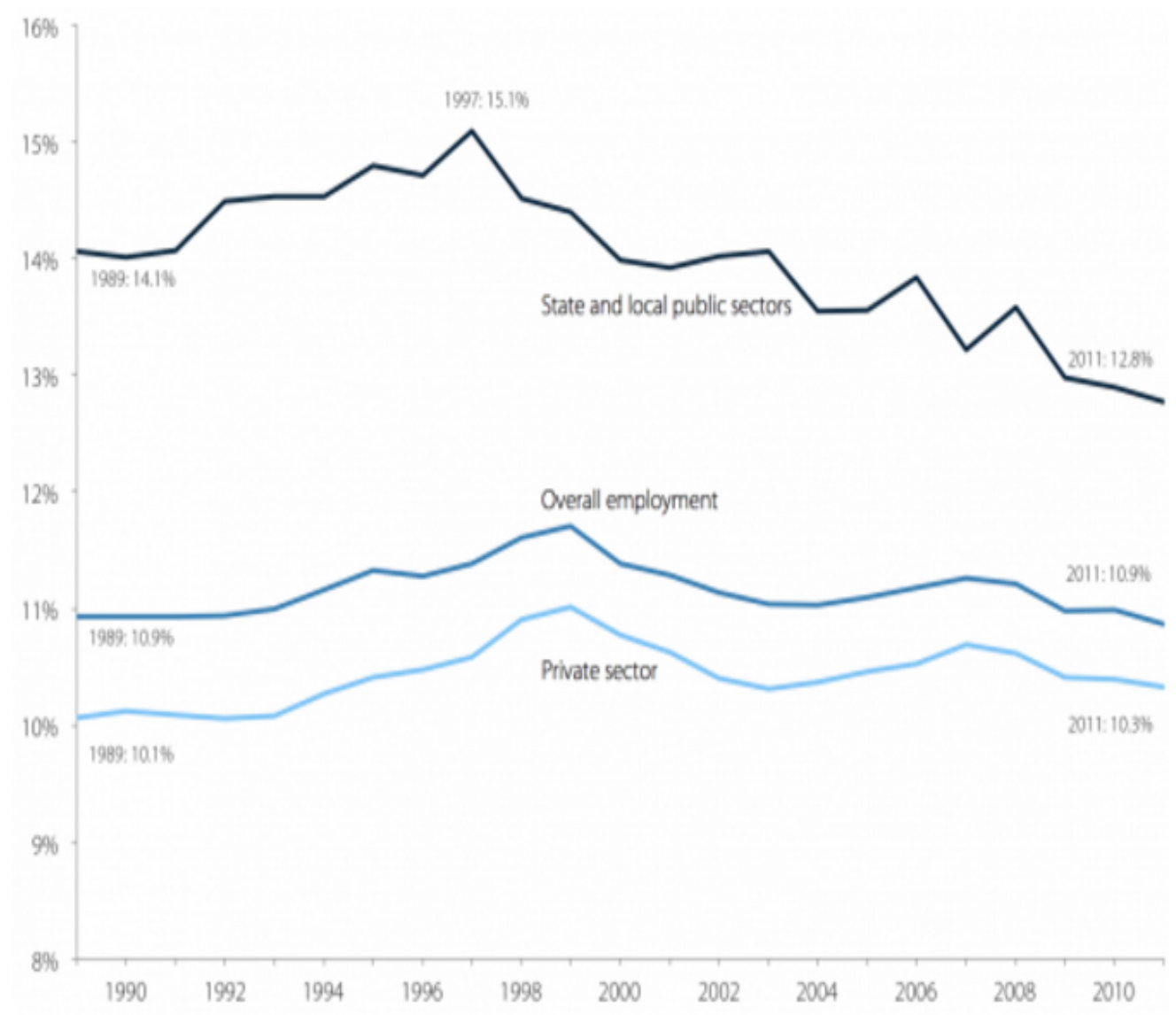

Source: Cooper et al., "The Public -Sector Jobs Crisis," based on an analysis of Current Population Survey Outgoing Rotation Group microdata

Figure II.4, from a Census Department study done by Todd Gardner, shows the share that Blacks represent in government employment in the large metropolitan areas, where Blacks disproportionately live. ${ }^{32}$ Gardner is interested in the Black representation in government employment in proportion to their representation in the populations of those metropolitan areas. A value of 1.0 in his chart indicates that a group held the same proportion of government jobs as their proportion in the population. Values below 1.0 show under-representation relative to the

\footnotetext{
${ }^{32}$ Todd Gardner, "The Racial and Ethnic Composition of Local Government Employees in Large Metro Areas, 1960-2010", Center for Economic Studies, U.S. Department of the Census, 2012, at https://www2.census.gov/ces/wp/2013/CES-WP-1338.pdf . The chart that we reproduce comes from a summary of the study done by the Urban Institute, Metro Trends, "The Racial and Ethnic Composition of Local Government Employees in Large Metro Areas, 1960-2010," 2012, at http://www.metrotrends.org/commentary/race-and-local-government.cfm
} 
population proportions and values above 1.0, the reverse. Gardner divided jobs into low-paid jobs and high-paid jobs for his analysis. The chart shows how Blacks increased their representation substantially from the 1960s in low-paid jobs after which representation ceased growing and declined after the 1990s. Of more interest are high-wage jobs, in which Blacks greatly increased their representation from the 1960s to the 1990s, at which point representation also began a decline.

\section{Figure II.4: Representation in state and local government jobs, 100 largest metropolitan areas, percent of jobs/percent of population}

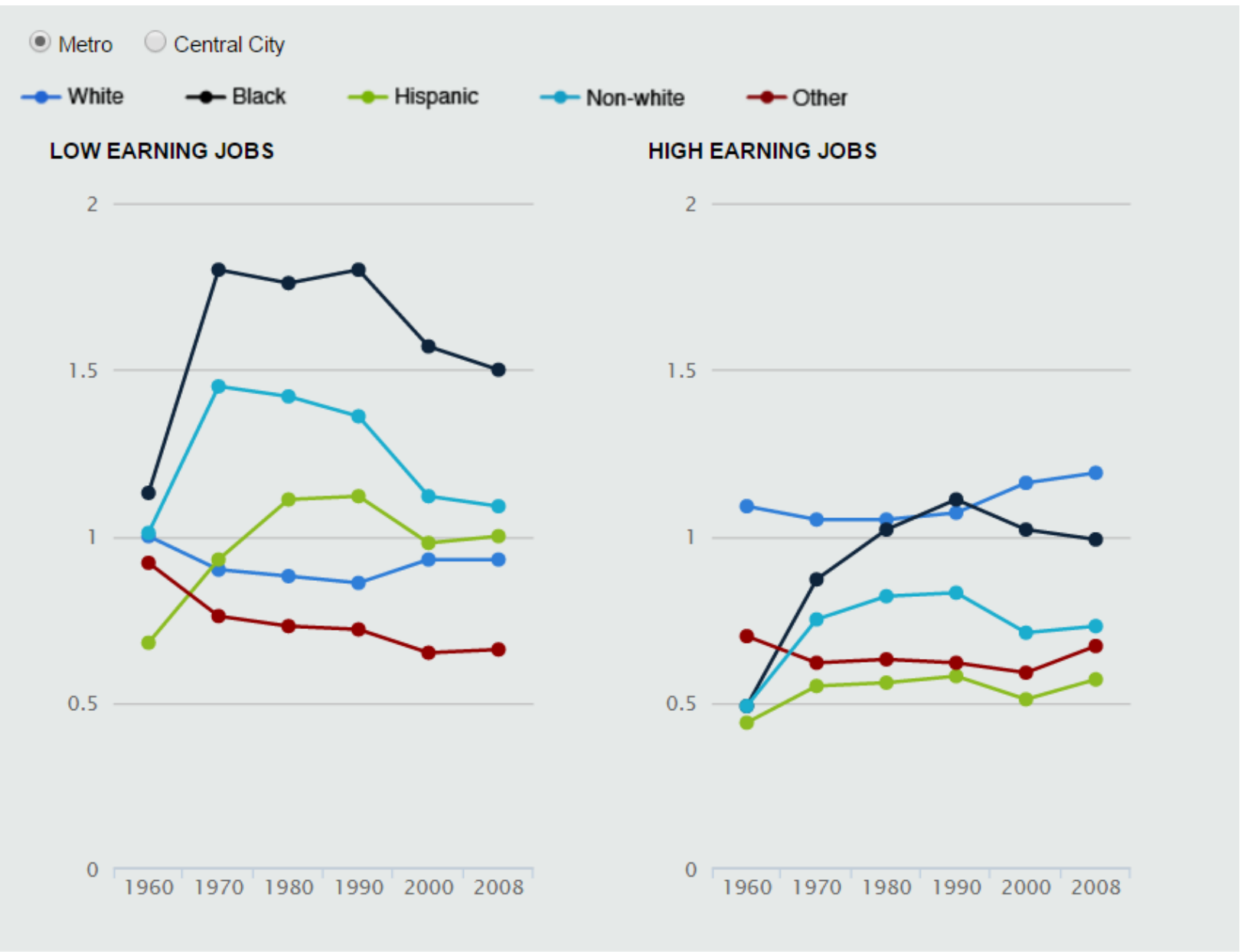

Source: Restricted-use 1960,1970,1980,1990, and 2000 U.S. decennial census microdata and 2006-2010 American Community Survey (ACS) data (approximated above by "2008*"). Race is defined as non-Hispanic White, non-Hispanic Black/African American, Hispanic (of any race), and Other Races (including multiple races reported). Al/ MSAs are standardized to 2009 OMB CBSA definitions.

Source: Gardner, "The Racial and Ethnic Composition of Local Government Employees.”

Figure II.5 comes from the study by Cooper et al. and shows the serious blow the Great Recession dealt to jobs for Blacks in the government sector. Figure II.5 makes clear the differential effect of lost state and local government jobs on African Americans. ${ }^{33}$ In contrast, to the business sector, in which total employment has grown since 2010, the state and local government sector continued to lose employment through 2013 and grew by only about 1.0 percent from 2013 through $2016 .{ }^{34}$

${ }^{33}$ Cooper, Gable, and Austin "The Public-Sector Jobs Crisis", Figure G.

${ }^{34}$ Economic Report of the President 2018, Table B-14: Employees on nonagricultural payrolls, by major industry, 1974-2017. 


\section{Figure II.5: Percentage change in state and local government sector employment, by gender and race, 2007-2011}

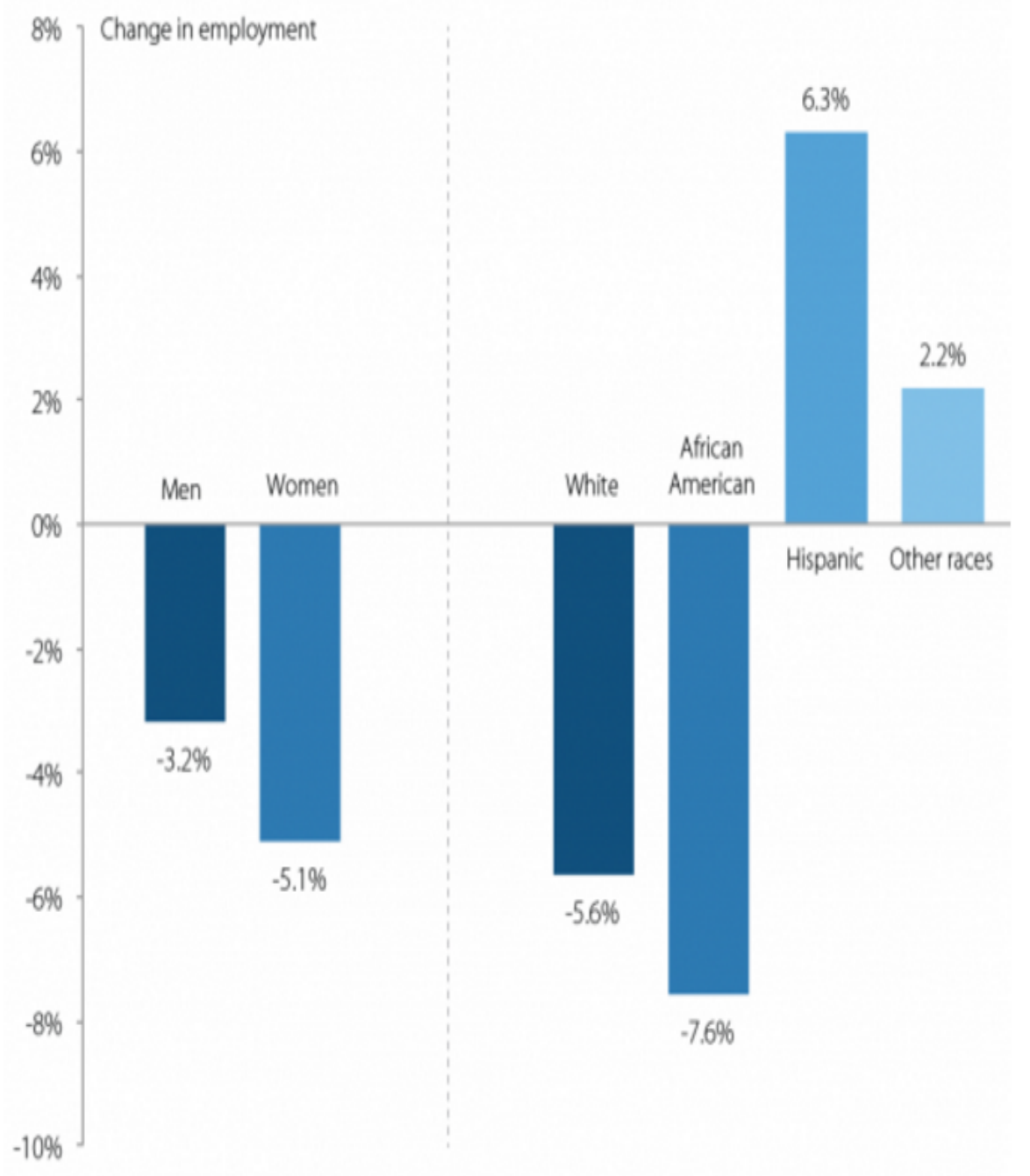

Source: Cooper et al., "The Public -Sector Jobs Crisis," based on an analysis of Current Population Survey Outgoing Rotation Group microdata

\section{Education}

A frequent explanation for why African Americans are concentrated in low-skilled jobs, get paid lower wages, and experience higher unemployment is that Blacks have lower educational attainment than whites. Economists' models have helped to create the primacy of education as the explanation of an individual's job, pay, and unemployment experience. In most economic research, education serves as the primary proxy for the productivity, or_skill, which an individual presents to the labor market and for which he or she is rewarded, given the demand for those skills. ${ }^{35}$

\footnotetext{
${ }^{35}$ It is not our purpose here to critique this narrow neoclassical economic vision of how skills are developed and how they are rewarded. We outlined in Working Paper \#1 the framework through which we analyze the jobs Blacks and whites have and the pay received held over the last fifty years. We develop this analysis in Working Paper \#3. See Lazonick et al., "Skill Development and Sustainable Prosperity," for a critique in the context of STEM jobs.
} 
In Table II.1 above, we have already examined educational attainment in the United States by race and ethnicity in 2018. The time path from the early 1970s of advancing educational qualifications for Blacks and whites is shown in Figures II.7 and II.8. ${ }^{36}$ These charts indicate that over the fortyyear period, Blacks have increased their educational attainment, as measured by the percent of Blacks 25 years of age and older with a bachelor's degree, from a starting position of about five percent to 28 percent, as we see in Figure II.8. For whites the increase is from about 22 percent to 39 percent. From the mid-1970s to the early 1990s in the population of 25-to-29-year-olds who would have recently acquired their bachelor's degree, the advance for both whites and Blacks stalled.

Figure II.7: High school and bachelor's degree attainment for white population, age 25 years and older, 1974-2017

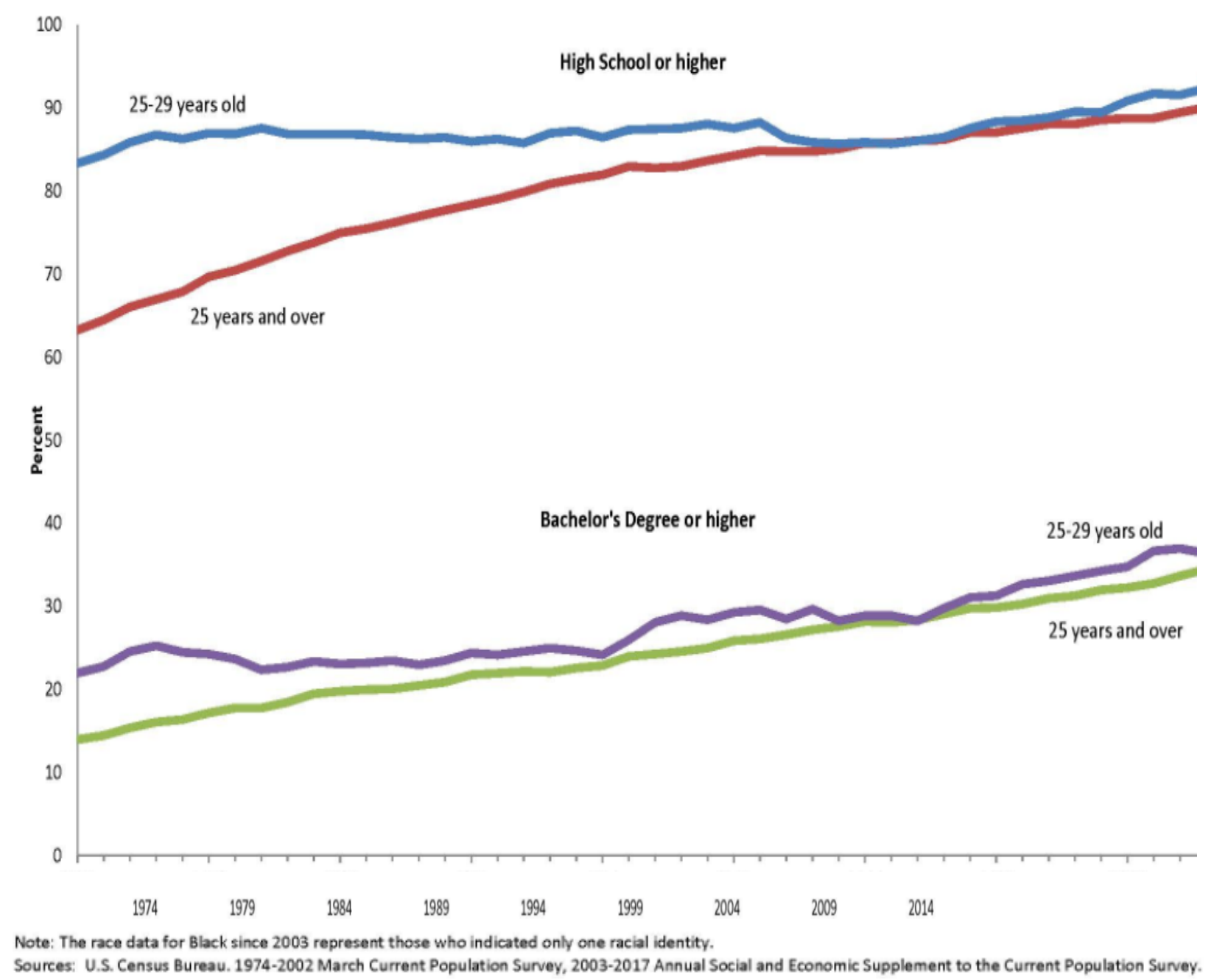

36 "Educational Attainment in the U.S" U.S. Census Bureau 2016, March 2017: Figures 7 and 8, at https://www.census.gov/library/visualizations/time-series/demo/cps-historical-time-series.html. 
Figure II.8: High school and bachelor's degree attainment for Black population age 25 years and older, 1974-2017

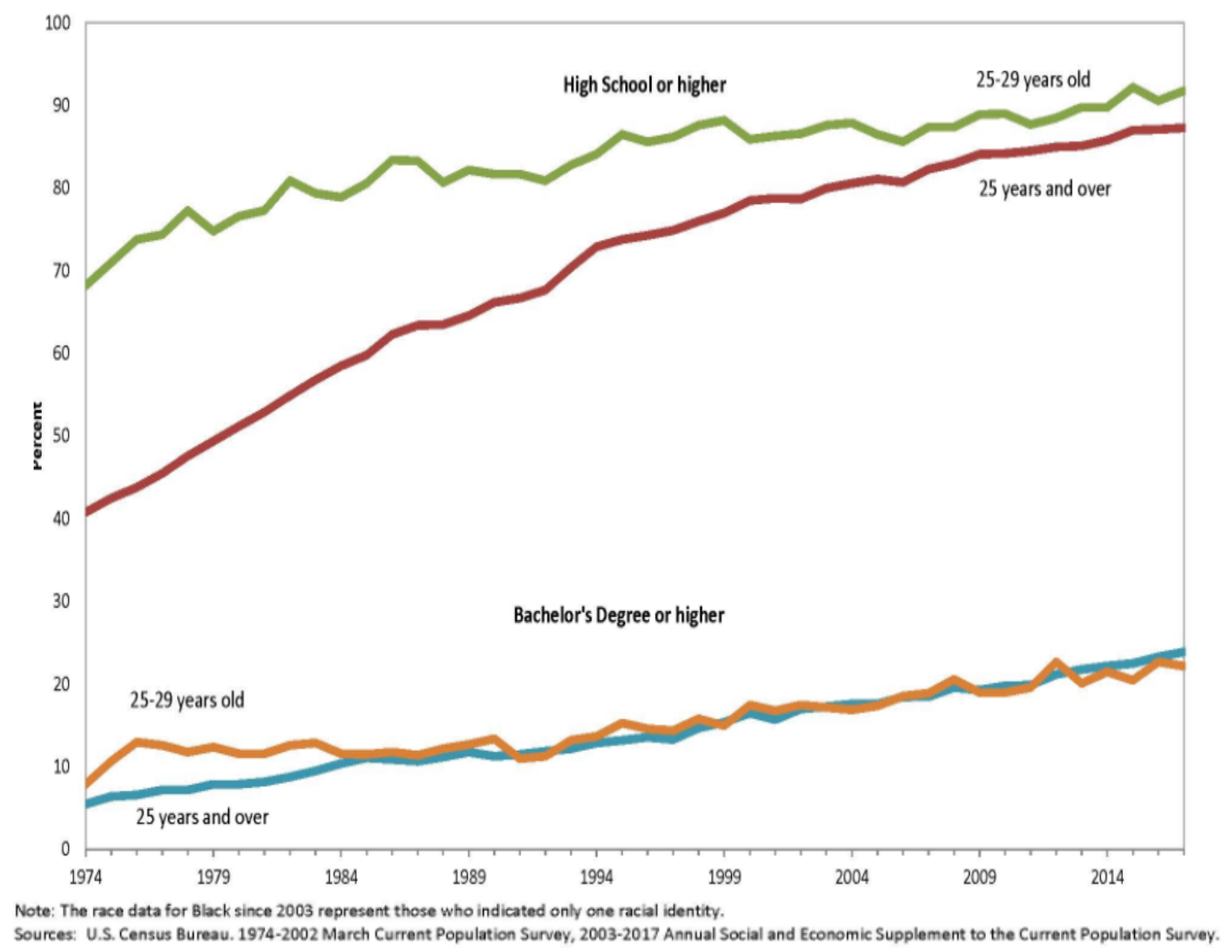

\section{Wage disparities}

While educational attainment clearly matters in access to jobs, particularly white-collar jobs, there is more to the story. The legal definition of discrimination in employment is making hiring, pay, or promotion, or other relevant decisions based solely on race, ethnicity, gender or a number of other ascriptive factors. ${ }^{37}$ In practice and in research, discrimination is often operationalized as disparate treatment of an equally qualified individual compared with other individuals, but who differs only in his or her race, or other protected characteristics. Researchers trying to measure the extent of discrimination in hiring, pay, or promotion typically use educational attainment as one of the key measures of an individual's potential or actual productivity, and hence his or her qualifications. Actual productive capability is very hard to measure, so it rarely is used as on objective employment criterion. Once education and other possible measures of qualifications are

\footnotetext{
${ }^{37}$ Equal Employment Opportunity Commission, "Types of Discrimination: Race/Color" https://www.eeoc.gov/laws/types/race color.cfm
} 
statistically controlled for, any residual difference in pay, or the probability of hire or promotion, is the measure of discrimination, or disparate pay. ${ }^{38}$

Valerie Wilson and William Rogers have done a comprehensive analysis of wage disparities by race, using micro data from the Current Population Survey.$^{39}$ Of the many findings, we only report the ones that are most germane to our study. They find a wage gap between Blacks and whites, adjusting for a host of variables, in all of the statistical models they report. A particularly important finding is that, adjusting for education and experience and other factors, the gap between the pay of Blacks and whites is widening. This growing gap is made clear in Figure II.9, which shows that overall, the adjusted wage differential for Black men working full-time went from a just under 17.0 percent in 1979 to 22.0 percent in 2015. The unadjusted gap for all men (which reflects less and decreasing full-time work or no work at all among Black men compared with white men) starts higher at 22.0 percent in 1979 and rises to 31.0 percent by 2015. For full-time women, the adjusted gap started much smaller, at 4.5 percent, but increased more sharply to 11.7 percent over the same period. The unadjusted gap for all women, similarly to that for Blacks, starts higher and rises to a higher level.

Figure II.9: Average hourly Black-white wage gaps, by gender, 1979-2015 (adjusted and unadjusted)

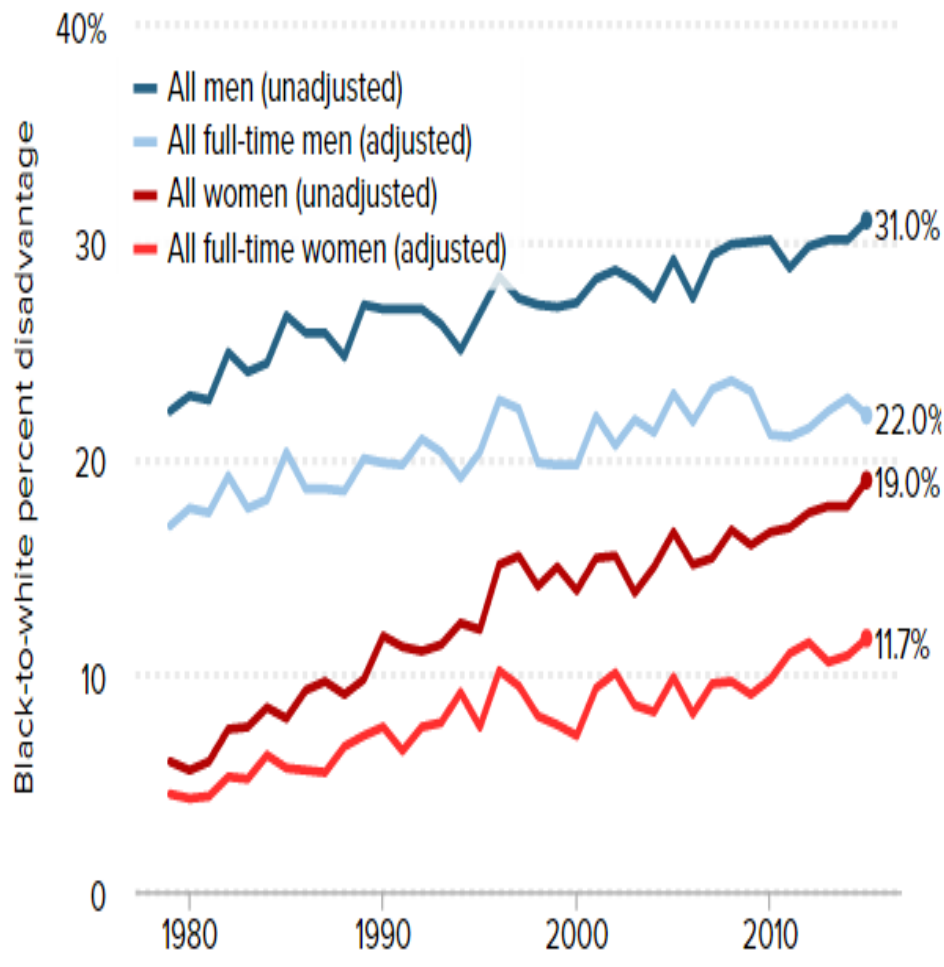

Source: Wilson and Rodgers, "Black-White Wage Gaps," Figure B.

Note: The adjusted wage gaps are for full-time workers and control for racial difference in education, potential experience, region of residence, and metro status.

\footnotetext{
${ }^{38} \mathrm{We}$ discuss discrimination and assessing the extent of discrimination further in Working Papers \#5.

${ }^{39}$ Valerie Wilson and William M. Rodgers III, "Black-White Wage Gaps Expand with Rising Wage Inequality,” Economic Policy Institute, September 2016, at https://www.epi.org/publication/Black-white-wage-gaps-expand-with-rising-wageinequality/.
} 
The analysis of wage differentials across individuals has become increasingly sophisticated by adjusting for more and more factors, or explanatory variables, that might influence wages and by using better statistical techniques. Wilson and Rogers are careful and thorough in considering many dimensions for adjustment and in trying to explain the time path of wage differentials. The statistical technique they use generates separate estimates for the effect of changes in the differential level of the explanatory variables between Blacks and whites, and changes in the differential impact each variable has on the wages of Blacks compared with the wages of whites. ${ }^{40}$ They look at the impacts of changes in the differential levels of education and unionization and changes in the differential composition of employment across occupations and industries. They then estimate the differential payoff to Blacks and to whites of these variables.

In brief, they find that different levels of education and experience contribute to the wage gap for men and even more so for women, with the widening wage gap among high-school-educated men contributing to the widening wage gap for men. The decline in unionization contributes to the change in the wage gap for men, because the wage of Black men is closer to that of white men in unionized jobs compared with non-unionized jobs and because Black men earn more in unionized jobs than do similar Black men in non-unionized jobs. In addition, Wilson and Rogers find that the wage advantage for Black men from being in unionized jobs has decreased. The change in the composition of employment of Blacks and whites across occupations and industries does not contribute appreciably to understanding the widening wage gap.

A great deal is left "unexplained" after adjustments are made for the observed differences across individuals, using the accepted statistical techniques. The unexplained portion is significantly more than the portion of the wage differential explained by the adjustments. The unexplained portion of the wage differential is typically attributed to unobserved differences across individuals such as motivation and social networks, as well as to discrimination. Wilson and Rogers find that changes over time in the unobserved differences and in discrimination account for more of the widening wage gap than do changes in the factors they can measure.

While measures of the level and trends in wage gaps between Blacks and whites are an important part of the assessment of Black employment 50 years after the passage of the Civil Rights Act, they do not provide a substantive explanation for why the gaps have evolved this way. Although Wilson and Rogers attempt to illuminate the influences of variables such as education, unionization and others through a widely-used statistical decomposition technique, there is no explanation for the changes in amounts of education or unionization possessed by each group or for the changes in the wage payoff to education or unionization, for example. For that explanation, as we argue throughout this study, it is necessary to look at changes in the employment relations, wage setting practices, and job creation strategies of the major business organizations that provide the employment and pay the wages.

\footnotetext{
${ }^{40}$ The technique is a "Oaxaca decomposition" of the observed changes in the gaps into changes in the amounts that each group possesses of a particular variable such as education or unionization and changes in the wage payoff (among whites) of having a higher level of the particular variable.
} 


\section{Unemployment}

The unemployment rate for African Americans is significantly higher than it is for whites as is the duration of spells of unemployment. African Americans experience greater unemployment at all levels of education.

The problem of Black unemployment is manifest in the next two charts from the Center for Economic Policy Research ${ }^{41}$ and a third from the Bureau of Labor Statistics. ${ }^{42}$ Figure II.10 shows unemployment rates for 2015 and displays the often-remarked fact that unemployment rates for Blacks are twice that of whites, a gap that holds for both men and women.

Figure II.10: Unemployment rates by race and gender, 2015

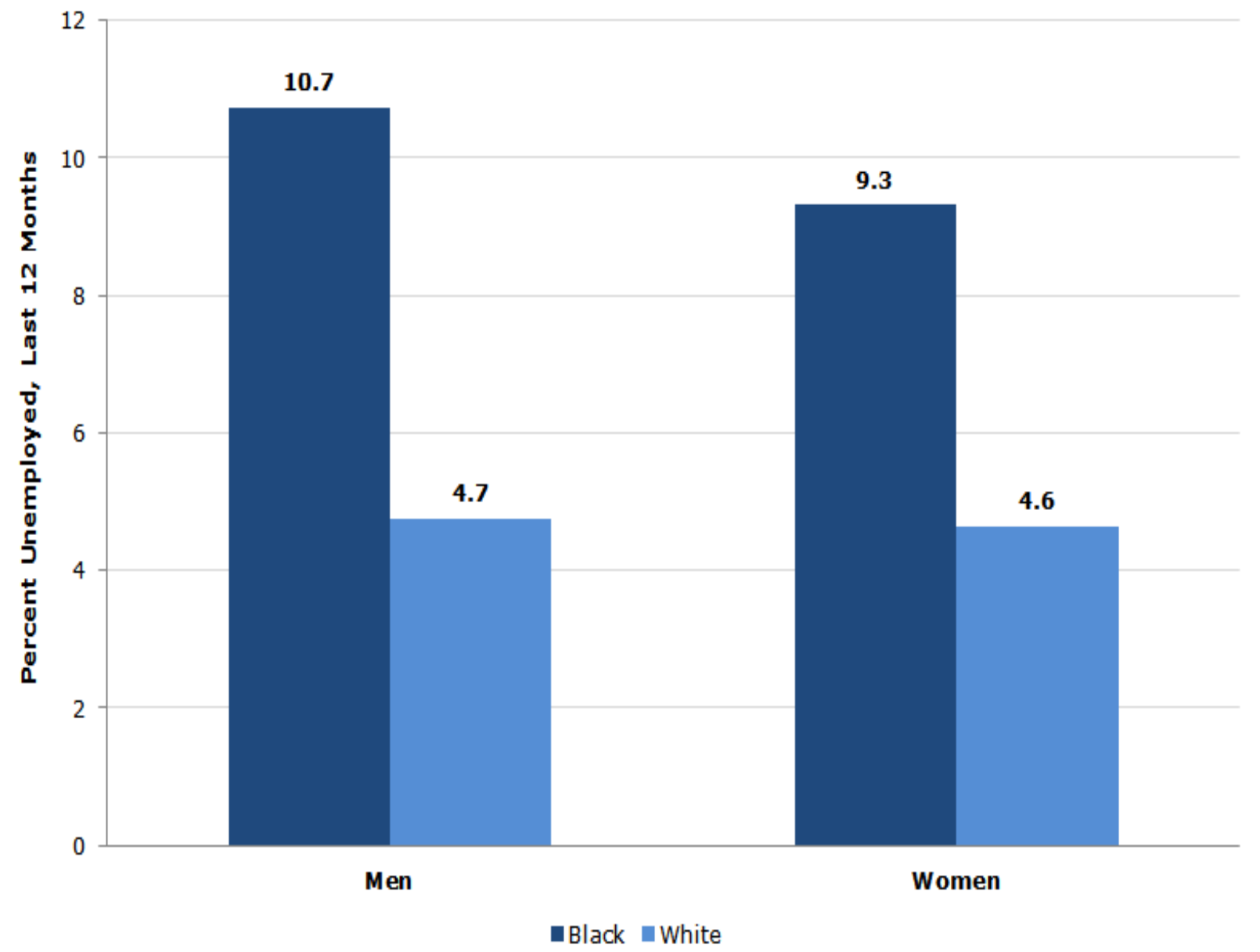

Source: Buffie, “The Problem of Black Unemployment”, Figure 1.

Figure II.11 provides unemployment rates by education level, showing that the gap persists at all education levels, but is highest - more than two times - at the lowest level of education (less than

\footnotetext{
${ }^{41}$ Nick Buffie, "The Problem of Black Unemployment: Racial Inequalities Persist Even Amongst the Unemployed", Center for Economic Policy Research, November 2015: Figures 1 and 3, at http://cepr.net/blogs/cepr-blog/the-problem-of-Blackunemployment-racial-inequalities-persist-even-amongst-the-unemployed Figure 1.

${ }^{42}$ BLS Reports, "Labor force characteristics by race and ethnicity", 2016 October 2017: Chart 5., at https://www.bls.gov/opub/reports/race-and-ethnicity/2016/home.htm
} 
high school), and declines steadily as education level increases. Figure II.12 displays the time path of unemployment rates by race and ethnicity from 1973 to 2015, speaking the problem loud and clear. The Black unemployment rate was more than two times the white rate at the beginning of the period. The gap was widest in the early 1980s, during the severe recession of that time. The gap narrowed to about two times during the 1990s as labor markets tightened, where it is now. The unemployment gap in these charts does not tell the entire story, however. Black rates of involuntary part-time employment are higher than for whites (6.2 percent compared to 4.6 percent) and their durations of unemployment are on average longer. ${ }^{43}$ In addition, the employment-to-population ratio for Black men has been significantly lower than for white men for several decades and the gap grew sharply during the Great Recession, indicating both higher unemployment rates and higher rates of nonparticipation in the labor force for Blacks. ${ }^{44}$

Figure II.11: Unemployment rates by race and education, 2015

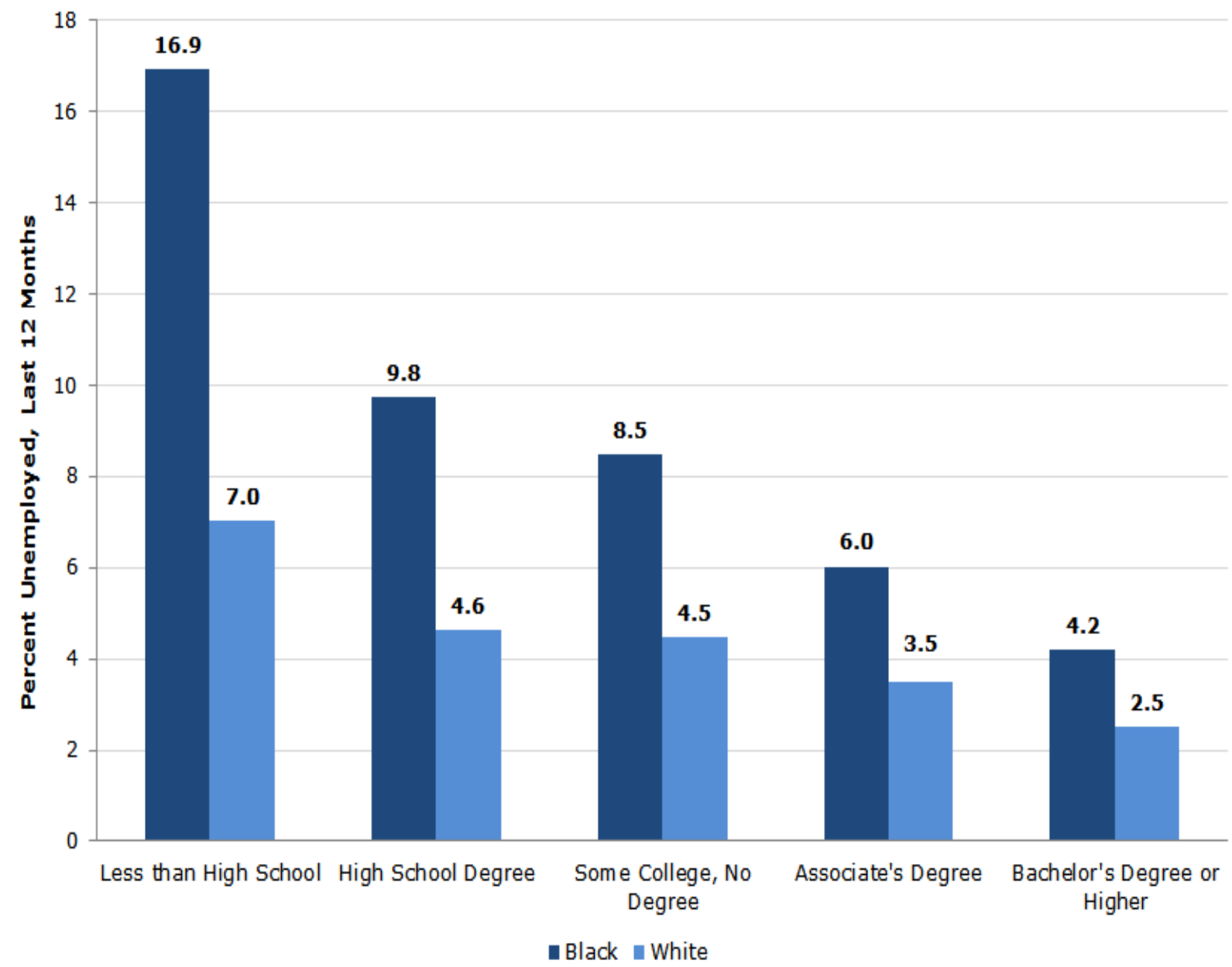

Source: Buffie, "The Problem of Black Unemployment", Figure 3.

\footnotetext{
${ }^{43}$ Nick Buffie, "The Problem of Black Unemployment," Figure 4.

44 "The African-American Labor Force in the Recovery," U.S. Department of Labor, February 2012: Figures 1 and 8. https://www.census.gov/hhes/socdemo/education/data/cps/historical/index.html
} 


\section{Figure II.12: Unemployment rates by race and Hispanic or Latino ethnicity, annual averages, 1973-2018}

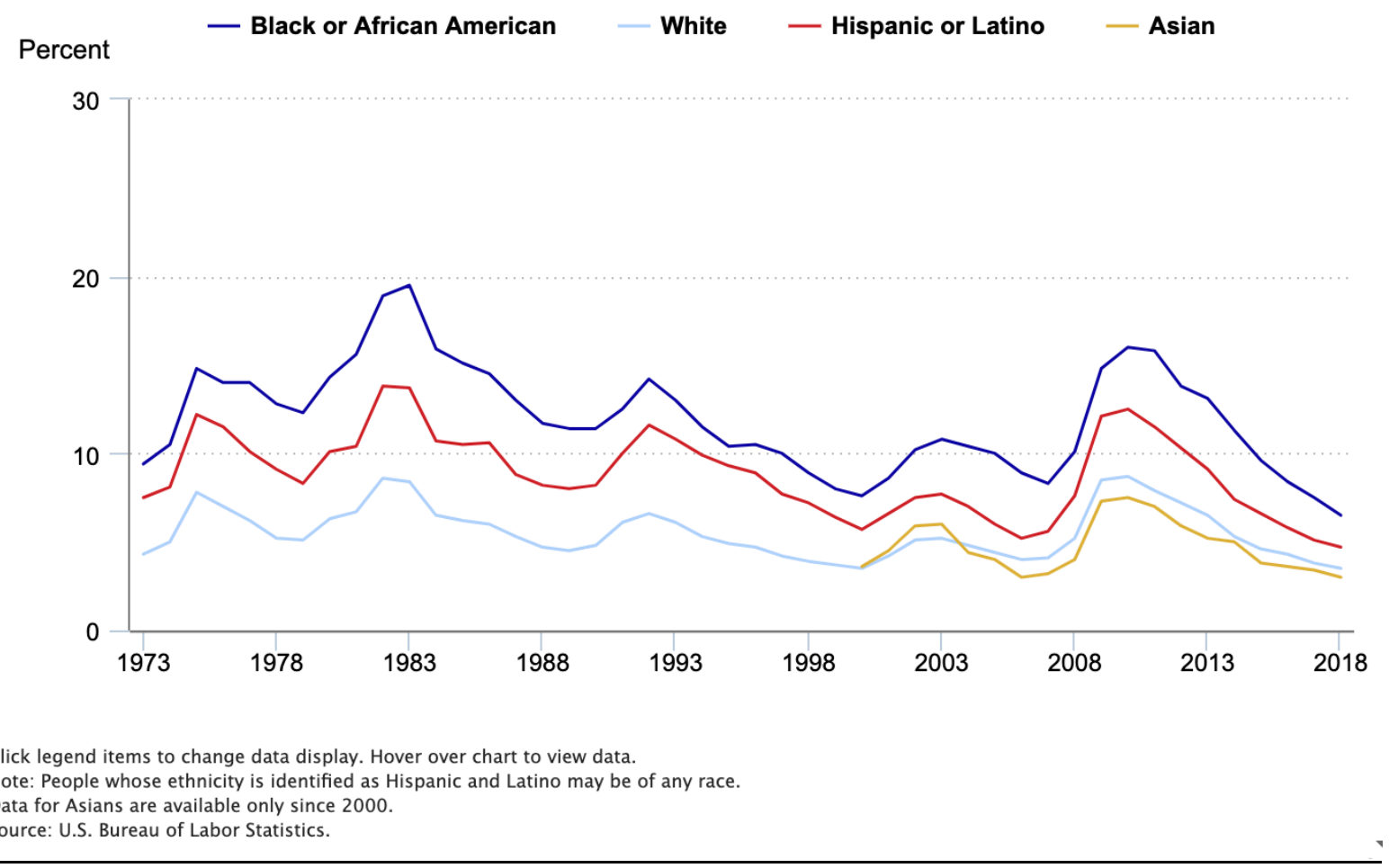

\section{Wealth}

If one has not inherited it, the ability to accumulate wealth depends on having a decent job over an extended period of time; a job with good pay, skill building and reasonable security and career prospects. The income stream from such jobs allows direct savings, contributions to retirement savings, building liquid savings that can buttress against income loss and emergencies, and buying a home that can enable further wealth accumulation. Wealth can in turn affect one's own earnings as well as the earnings of the next generation because it can allow a move to a location with superior schools and finance training and higher education. In recent decades, student debt has become an important and growing negative component of wealth that depresses the ability to accumulate wealth and may reduce earnings by influencing job choices made soon after leaving college or graduate school. Throughout the twentieth century and before, Blacks' ability to accumulate wealth through buying their own home, a major source of wealth accumulation for middle-class Americans, was restricted by federal policy, discriminatory bank lending behavior and overt exclusion resulting from the behavior, often violent, of residents in white neighborhoods ${ }^{45}$ The housing component of wealth became increasingly important during the housing bubble. With concurrent changes in mortgage finance that included predatory and dangerously overleveraged lending, the collapse of the housing market and the resulting Great Recession substantially lowered the wealth of both whites and Blacks, but disproportionately for Blacks.

\footnotetext{
${ }^{45}$ Richard Rothstein, The Color of Law, Liveright Publishing Company, 2017
} 
In this section, we show the glaring gap in wealth accumulation between Blacks and whites. While a gap should be no surprise, as employment opportunity for African Americans to access jobs with good pay and security has always trailed that of whites, the size of wealth disparities is extremely large and has worsened over the last fifty years. We can see the cumulative effect of unequal job opportunity from data on the earnings of Blacks and whites accrued over a lifetime of work. The accumulated earnings of Black men nearing retirement age in 2012 was only two-thirds that of white men. The figure for Black women is 87 percent of white women but less than half that of white men. Figure II.13 shows these disparities. ${ }^{46}$

The wealth gap has grown over recent decades, widening dramatically during the Great Recession. ${ }^{47}$ Figure II.14 shows the growing severity over time and the staggering ten-fold size of the current wealth gap between Blacks and whites. ${ }^{48}$

\section{Figure II.13: Average accumulated real lifetime earnings at ages 58-62 for people born 1950-54 by gender and race/ethnicity}

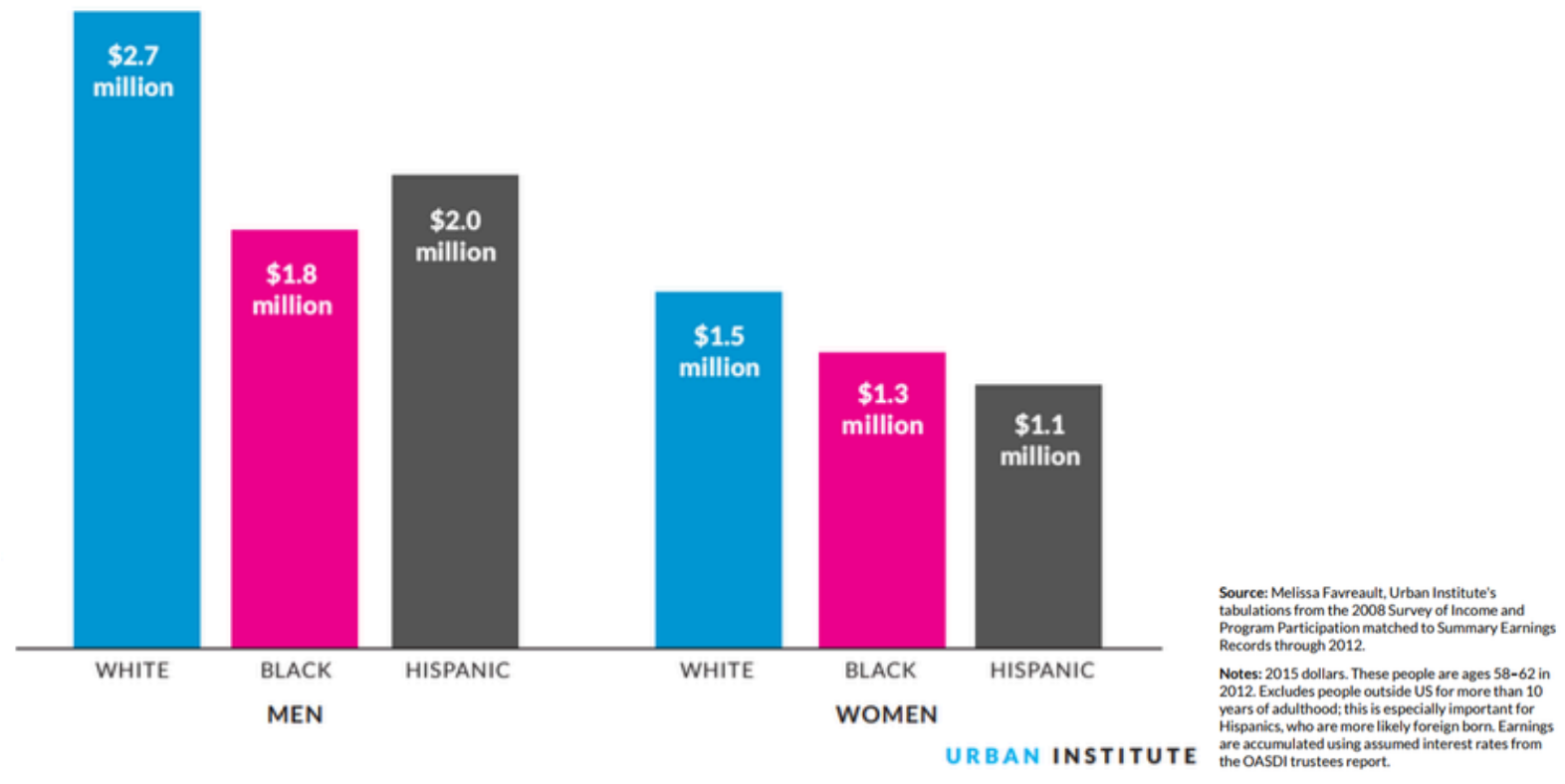

46 This chart was produced by researchers at the Urban Institute, using data from the Survey of Consumer Finances. Urban Institute, "Nine Charts about Wealth Inequality in America (Updated)," October 2017, at http://apps.urban.org/features/wealth-inequality-charts/ Chart 5.

47 The racial gap in median wealth is larger in relative terms than for average wealth, presumably because the few extremely wealthy African American families pull the African American average toward the white average. For the same reason, the absolute size of the gap is larger for average wealth. See Urban Institute, "Nine Charts" for the average wealth levels for whites and African Americans.

48 Urban Institute, "Nine Charts," Chart 4. Other researchers from whom we draw below use different datasets such as the Panel Study of Income Dynamics and the Survey of Program Participation. The wealth figures differ only slightly, and the essential picture is the same. 


\section{Figure II.14: Median family wealth by race/ethnicity, 1963-2016}
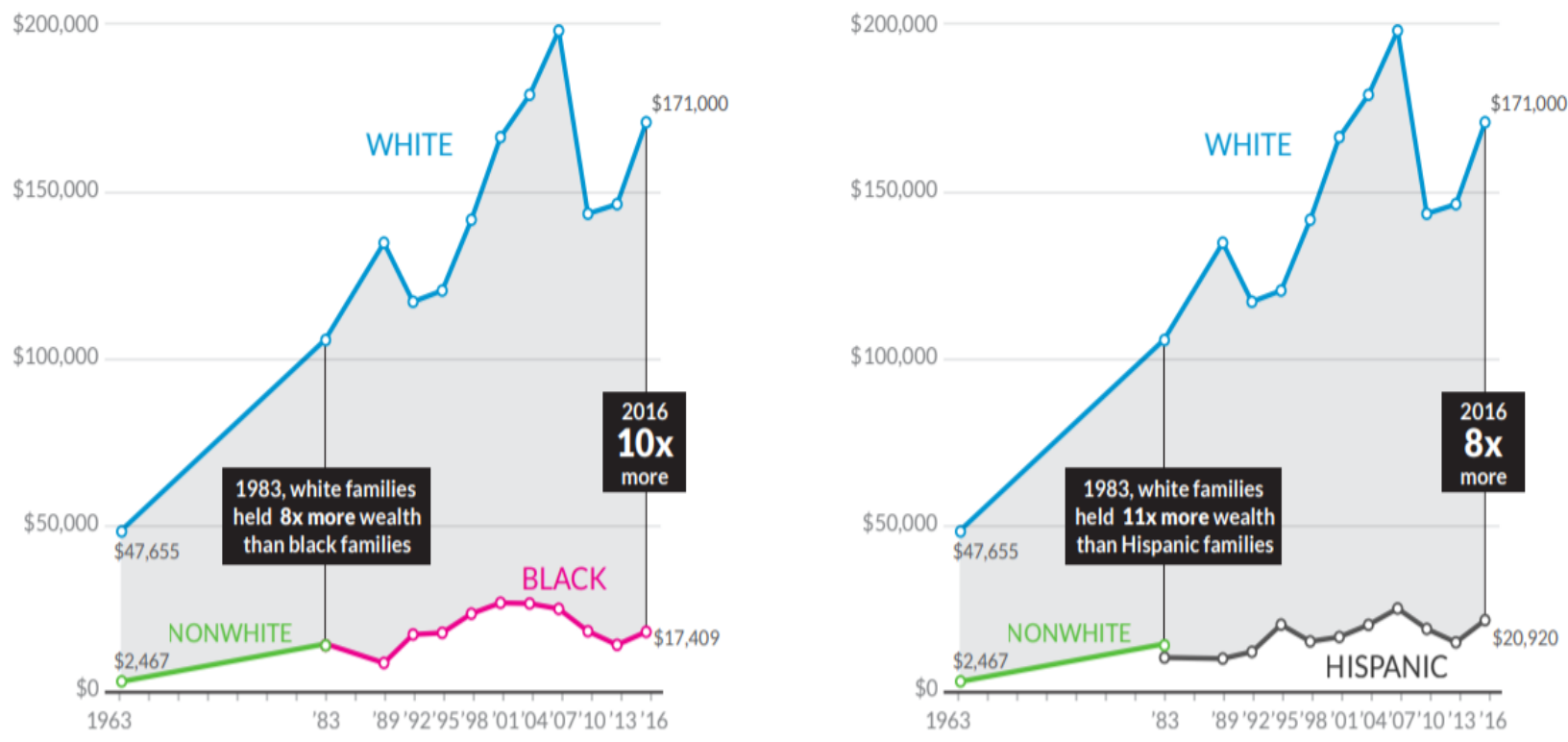

Source: Urban Institute calculations from Survey of Financial Characteristics of Consumers 1962 (December 31), Survey of Changes in Family Finances 1963 , and Survey of Consumer Finances 1983-2016.

Notes: 2016 dollars. No comparable data are available between 1963 and 1983. Black/Hispanic distinction within nonwhite population available only in 1983 and later.

Housing equity is a critical part of the story of the Black-white wealth gap. ${ }^{49}$ Housing equity is the major component of wealth for most families and is especially the case for African-American families who own houses. Through borrowing against housing equity, families also provide financing for education and other investments that will influence the socioeconomic status of their children. The rate of homeownership for Blacks is significantly lower than for whites, as Figure II.15 indicates. ${ }^{50}$

Looking at families that own a home, Figure II.16, from Sarah Burd-Sharps and Rebecca Rasch, shows how much more important home equity has been as a component of wealth for AfricanAmerican households compared with white households for the last two decades.$^{51}$ Given that Black communities were targeted for sub-prime and predatory lending, it is not surprising to see in this chart how housing equity as a fraction of all wealth shot up among Blacks during the housing build up, much more than it did for whites, making Blacks that much more vulnerable to the subsequent housing collapse..$^{52}$

49 The shameful history of the deliberate government policies, discrimination by banks, racial violence that prevented Blacks from buying houses or geographically segregated the housing they could buy is given in Rothstein, The Color of Law, and Ira Katznelson, When Affirmative Action Was White: An Untold History of Racial Inequality in Twentieth-Century America, W. W. Norton, 2005.

${ }^{50}$ Urban Institute, "Nine Charts," Chart 6

${ }^{51}$ Sarah Burd-Sharps and Rebecca Rasch, "Impact of the US Housing Crisis on the Racial Wealth Gap Across Generations." Social Science Research Council, 2015: p. 11, Figures 3a and 3b, at https://s3 amazonaws.com/ssrccdn1/crmuploads/new publication 3/\%7B129CDF74-1F11-E511-940A-005056AB4B80\%7D.pdf

52 Ibid: p. 9; Wilhelmina Leigh and Daniel Huff, "African Americans and Homeownership: The Subprime Lending Experience, 1995 to 2007," Washington, D. C.: Joint Center for Political and Economic Studies, November 2007. 
Figure II.15: Homeownership rate by race/ethnicity, 1983-2016

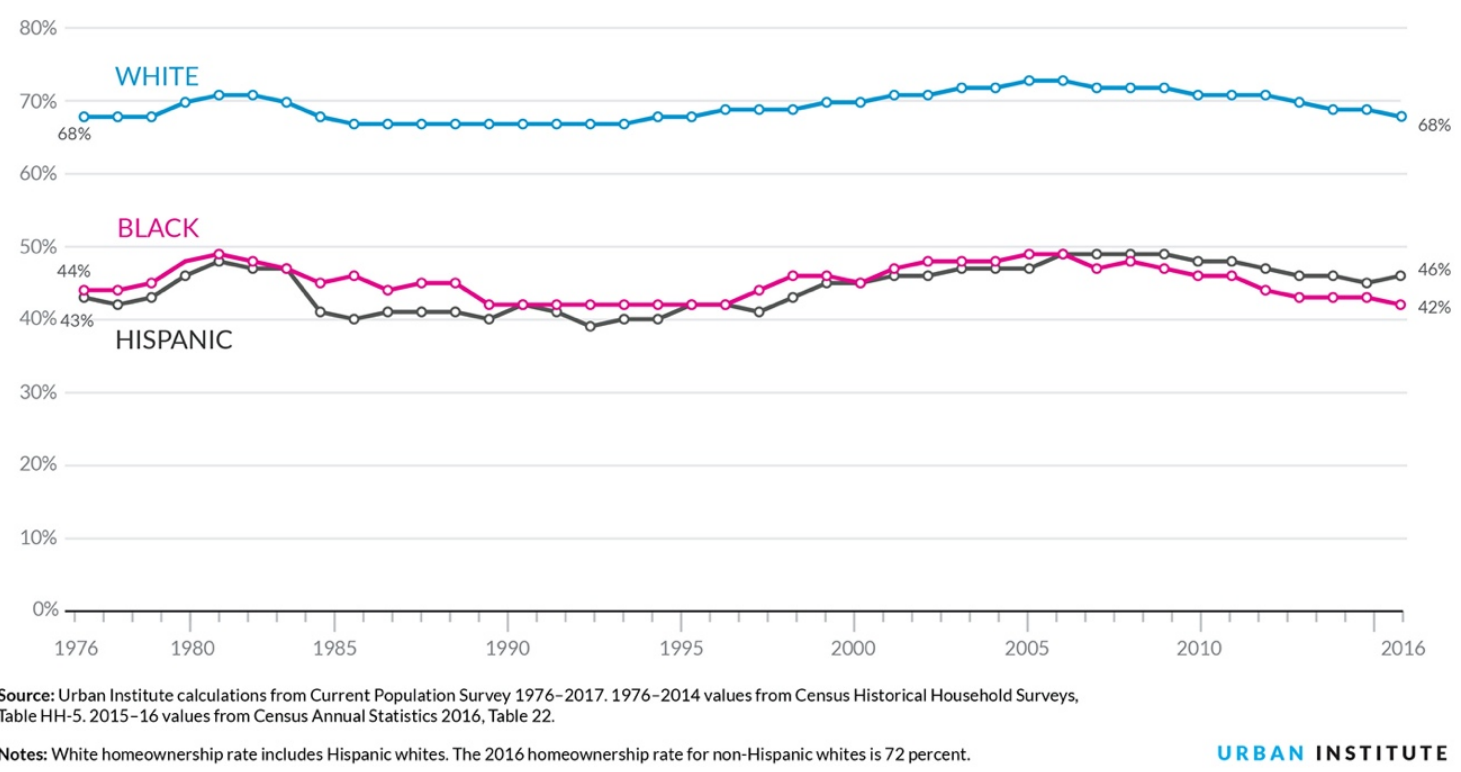

Figure II.16: Total wealth versus wealth excluding home equity, whites and Blacks

Whites

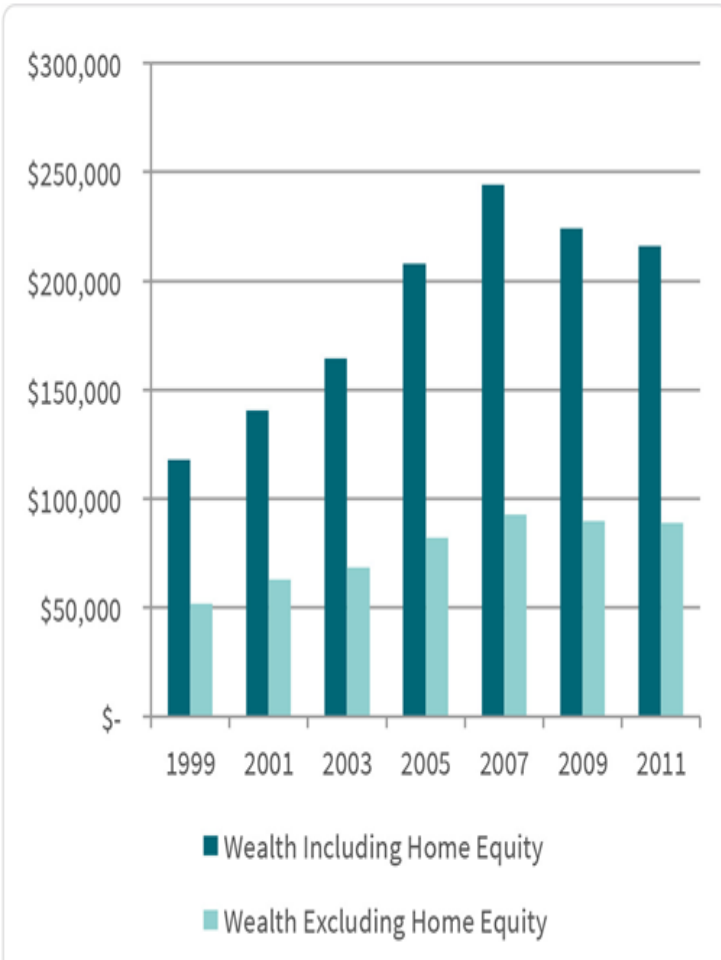

Blacks

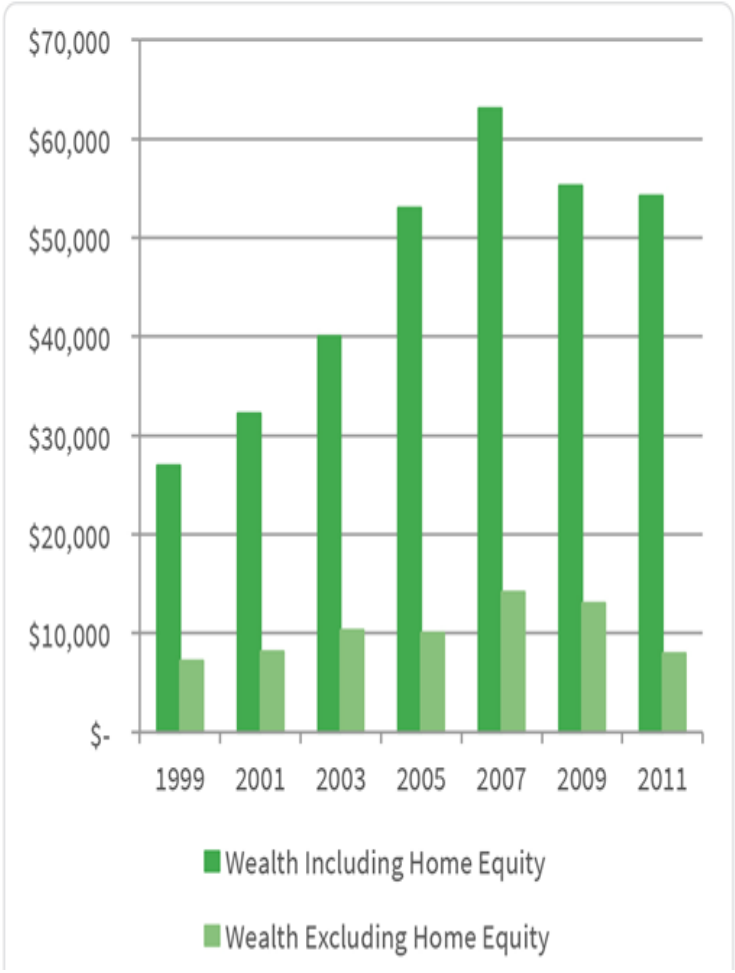

Source: Burd-Sharps and Rasch, "Impact of the U.S. Housing Crisis," Figures 3a and 3b,from data in the Panel Study on Income Dynamics (PSID) 
Figure II.17, from the authors of the previous chart, shows how African-American households in percentage terms invested more heavily in home equity than white families during the housing build up, lost substantially more than white households during the housing crash, and recovered much less than white families from 2009 to $2011 .{ }^{53}$ As we have emphasized, wealth generated by a secure steady income allows a family to invest for the future. The gap in wealth and the more damaging hit to wealth from the Great Recession affects the differential well-being of Blacks into the future. Burd-Sharps and Rasch have generated simulations to estimate how the current gap in wealth exacerbated by the Great Recession can extrapolate into increased gaps in the future. ${ }^{54}$

\section{Figure II.17: Percentage change in home equity during and after the housing boom}

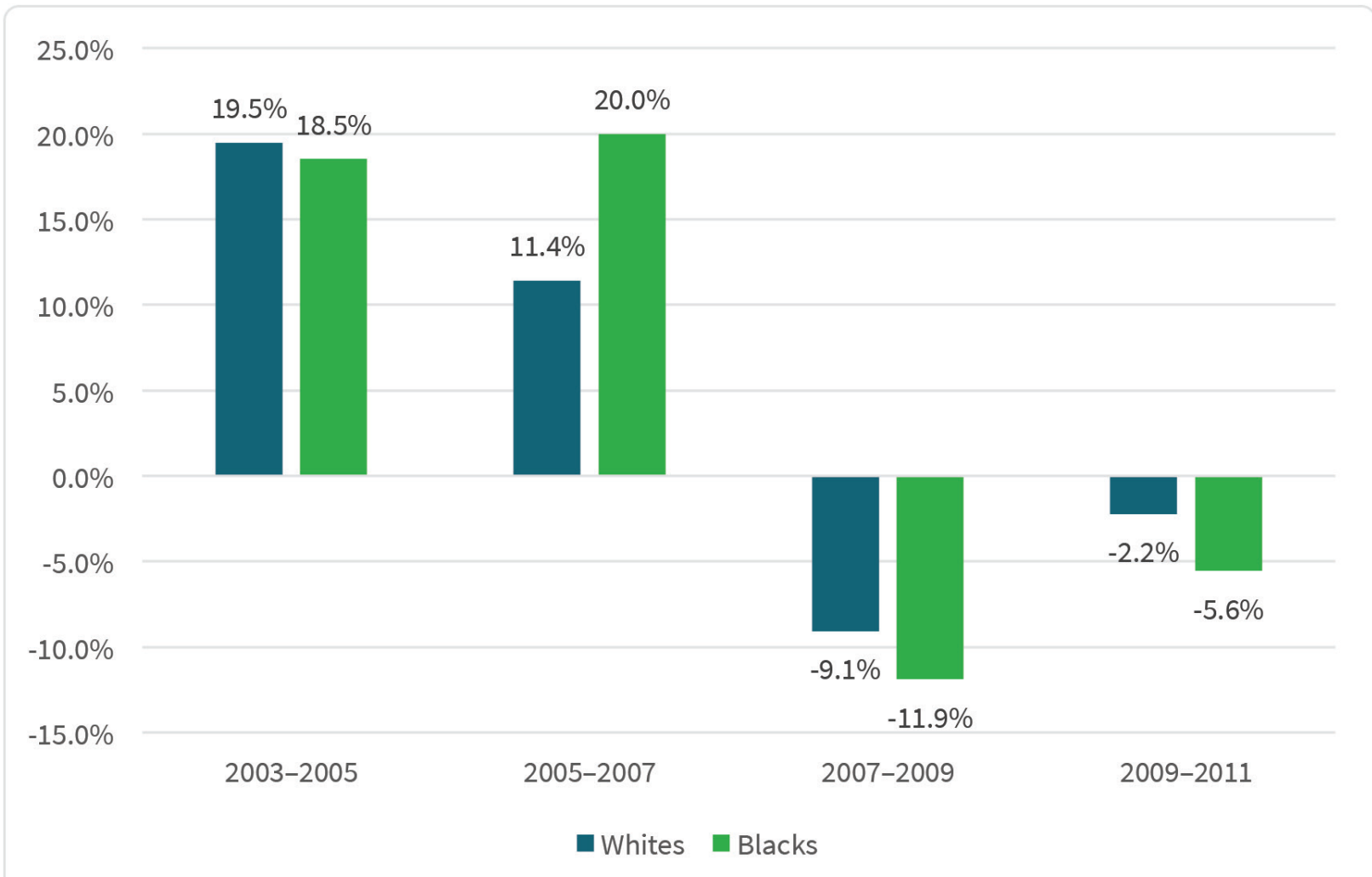

Source: Burd-Sharps and Rasch, "Impact of the U.S. Housing Crisis," from data in the Panel Study on Income Dynamics (PSID)

The high and rising interest rates for subprime and predatory mortgages disproportionately issued to Blacks, resulted in higher rates of delinquency and foreclosure, as shown in Figure II.18 from the Bureau of Labor Statistics using data from the National Survey of Youth. ${ }^{55}$

53 Burd-Sharps and Rasch, "Impact of the US Housing Crisis," p. 13, Figure 5.

54 Ibid: 15-23. It is difficult to forecast such differences into the future, and we do not have the means to evaluate the actual estimates that the authors generated. The qualitative pattern they present is nonetheless important for understanding how differential job opportunity has translated into differential financial resources that will then, in the absence of significant changes in policy, influence disparities into the future.

55 Alison Aughinbaugh, "Patterns of homeownership, delinquency, and foreclosure among youngest baby boomers", Bureau of Labor Statistics, Beyond the Numbers, 2, 2, February 2013, Chart 4, at http://www.bls.gov/opub/btn/volume-2/patterns-ofhomeownership.htm. 
Figure II.18: Rates of delinquency and foreclosure by race/ethnicity, education, gender, and marital status, from 2007 to 2010 , for those who owned a home during these years

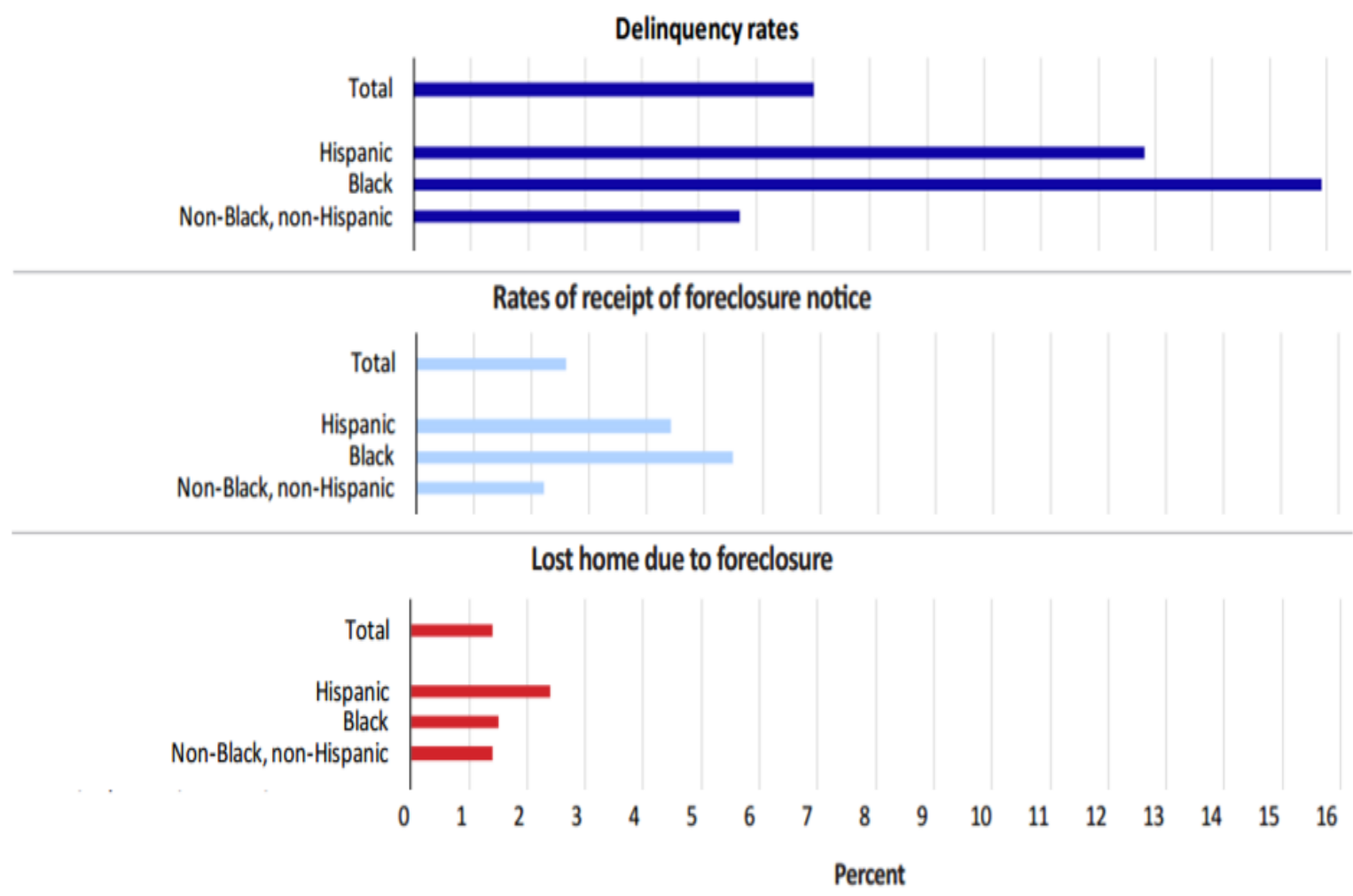

Note: Sample members of the NLSY79 are born from 1957 to 1964 and were living in the United States in 1979.

Source: U.S. Bureau of Labor Statistics, National Longitudinal Survey of Youth 1979 (NLSY79).

Employment in a stable and well-paid job helps an individual accumulate retirement savings, either as a defined-benefit pension, which has become less and less available, or through contributions to tax-sheltered retirement accounts and other savings vehicles. Retirement savings are also partially liquid and can be drawn upon in emergencies. For several decades, Blacks have been substantially behind whites in the amount of retirement savings they hold, and like other dimensions of wealth, the disparity has grown much wider, particularly during and since the Great Recession. Figure II.19, prepared by the Urban Institute, illustrates this growing gap. ${ }^{56}$

Blacks have less secure jobs on average, and their employers are less likely to offer retirement savings accounts. ${ }^{57}$ This disparity is compounded by the fact that Blacks tend to participate in retirement plans at a lower rate than whites (40 percent compared with 47 percent in 2013) and

\footnotetext{
${ }^{56}$ Urban Institute, "Nine Charts," Chart 7

${ }^{57}$ Urban Institute, "Nine Charts"; Karen E. Smith, "Low pension participation among minorities contributes to the wealth gap," Urban Institute, April 13, 2015, at https://www.urban.org/urban-wire/low-pension-participation-among-minorities-contributeswealth-gap.
} 
make lower contributions when they have retirement plans. ${ }^{58}$ In 2014,53 percent of whites and 47 percent of Blacks had retirement plans where they worked. ${ }^{59}$

Figure II.19: Average family liquid retirement savings, 1989-2016

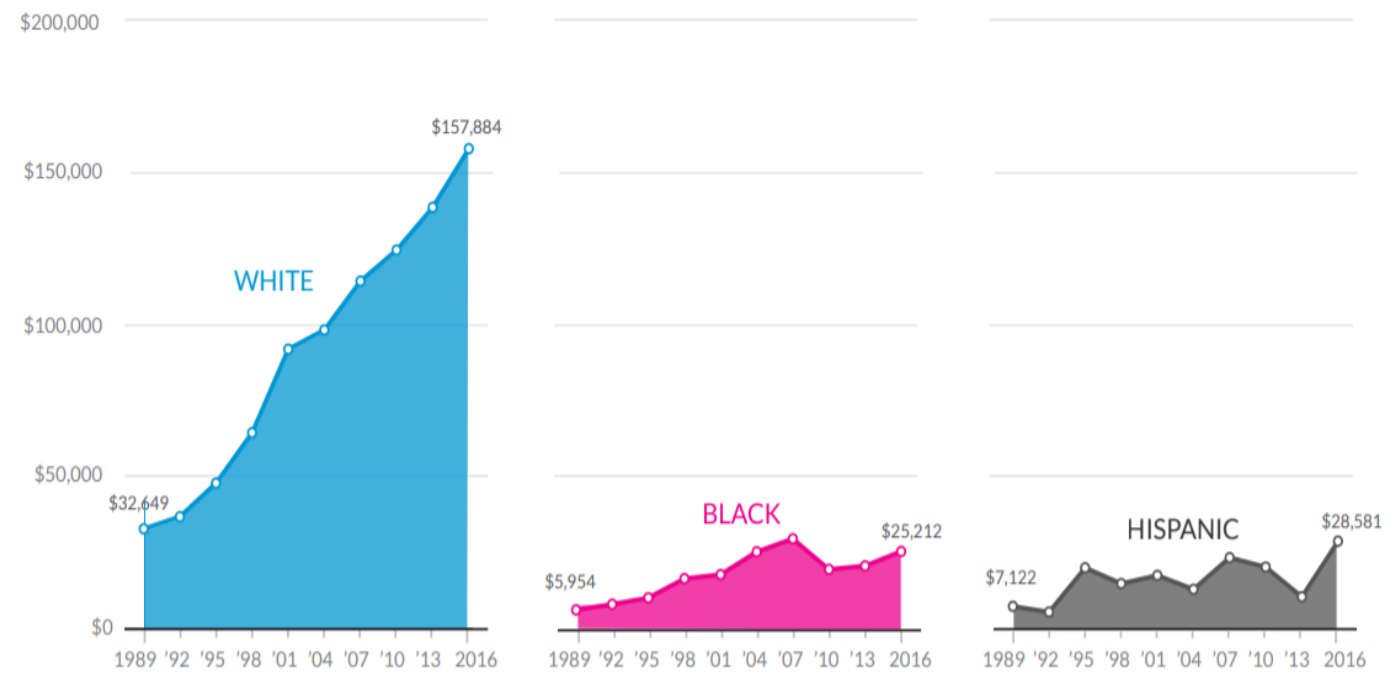

Source: Urban Institute calculations from Survey of Consumer Finances 1989-2016.

Notes: 2016 dollars. Liquid retirement savings include dollars in accounts such as 401(k), 403(b), and IRAs. Median liquid retirement savings for black and Hispanic families were zero from 1989 to

The gap is larger if one looks only at retirement plans where employers actually make a contribution; 42 percent for whites and 33 percent for Blacks in $2014 .{ }^{60}$ The transition to definedcontribution 401(k) and similar retirement savings plans from defined-benefit pension plans has disproportionately hurt Black workers. ${ }^{61}$ In 1983, 52 percent of Black workers and 53 percent of white workers were included in employer retirement plans. ${ }^{62}$ The striking differences shown in Figure II.19 are the results of the loss of the types of Old Economy employment with definedbenefit pensions and the shift from defined-benefit to defined-contribution pensions in the New

\footnotetext{
${ }^{58}$ Ibid. This undoubtedly is due in part to the fact that Blacks have lower family income and therefore less leeway to spare part of their salary to contribute to a retirement account. It may also be due to lower rates of financial literacy among Blacks compared with whites. The National Center for Educational Statistics reports the financial literacy scores from the Program for International Student Assessment (PISA) by race for 15-year-old students. In 2015, 41 percent of Black students versus 12 percent of white students were in the lowest category for the test, while only 1.4 percent of Black students versus 16 percent of white students were in the highest category. https://nces.ed.gov/surveys/pisa/pisa2015/pisa2015highlights 11f 1.asp. We did not find a study with a valid representational sample of adult Blacks and whites to compare to these results for students.

${ }^{59}$ Monique Morrissey, "White workers have nearly five times as much wealth in retirement accounts as Black workers", Economic Policy Institute, February 18, 2016. https://www.epi.org/publication/white-workers-have-nearly-five-times-asmuch-wealth-in-retirement-accounts-as-Black-workers/

${ }^{60}$ State of Working American, "Data Library," https://www.epi.org/data/\#cpsasec. The figures are drawn from the Current Population Survey.

${ }^{61}$ A defined-benefit pension plan provides a fixed amount per year to retired employees, with the amount determined by the employee's salary, typically in the last several years of employment and the length of the employee's tenure. A 401(k) retirement savings plan is a tax deferred savings account into which an employee may contribute a portion of his or her salary, to be drawn down following retirement. An employer may also contribute to this plan. To contribute, employers typically require that the employee be contributing to the plan. According to the Employee Compensation Survey of the Bureau of Labor Statistics, 49 percent of employers make contributions to their employees' accounts. The value of the savings account depends on the funds into which the savings have been invested, typically the choice of the employee, and how those funds have performed at the time of retirement.

${ }^{62}$ Morrissey, "White workers"
} 
Economy. ${ }^{63}$ Clearly, the retreat by companies from defined-benefit pensions to voluntary or defined-contribution 401(k) plans has affected the accumulation of wealth among Black households more than among white households and contributed to the racial wealth gap.

As indicated in the note to Figure II.19, beyond retirement savings, the median amount of liquid savings that whites have carried is very small and that Blacks have carried is essentially zero. Tippett et al., using different data, have very similar findings. ${ }^{64}$ They also find that almost three times as many African Americans (38 percent) as whites (14 percent) are devoid of any financial assets at all. ${ }^{65}$ Figure II.20 summarizes the higher losses for Blacks in the different components of wealth as a result of the Great Recession. ${ }^{66}$

\section{Figure II.20: Hispanics lost the most wealth during the Great} Recession, while Blacks fared worse than whites

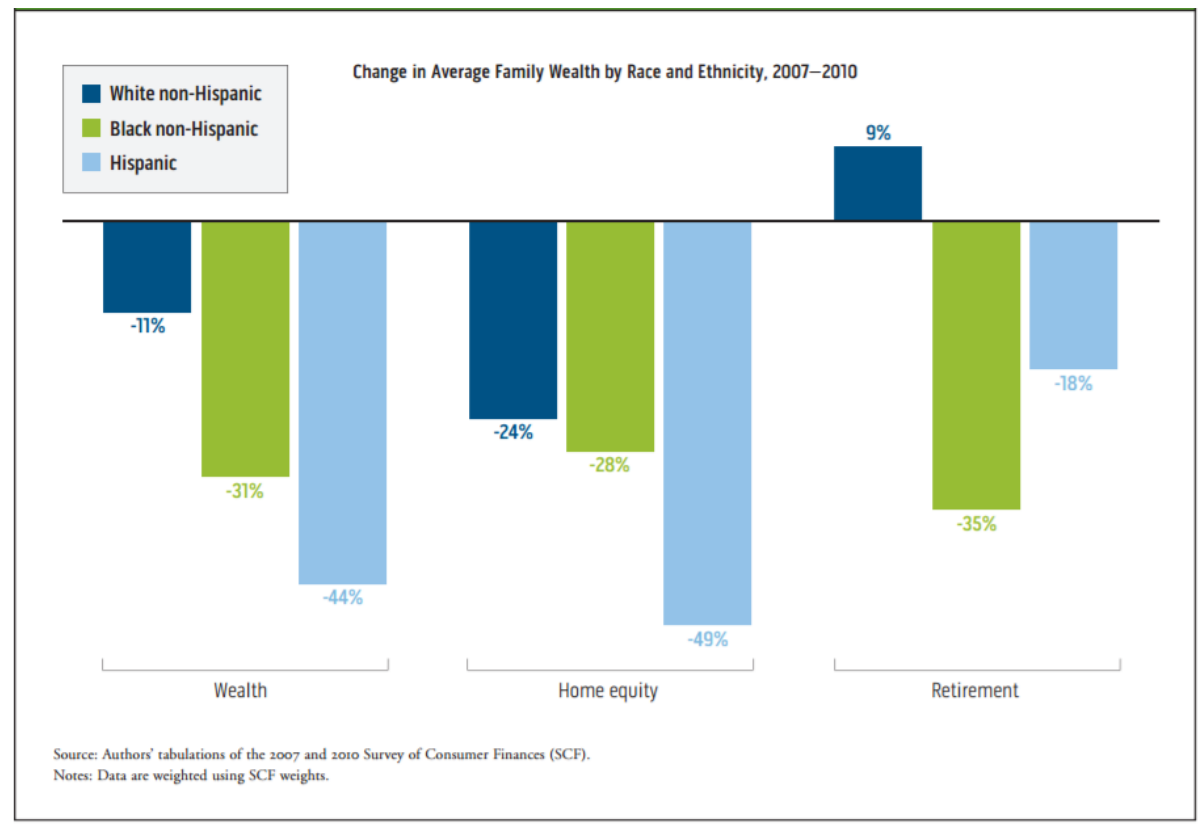

Source: McKernan et al., "Less than Equal," Figure 5, tabulations of the 2007 and 2010 Survey of Consumer Finances (SCF)

Wealth in the form of the ownership of corporate equity is enormously unequal across race. Lenore Palladino has recently analyzed the contribution of corporate equity ownership to the disparity of

\footnotetext{
${ }^{63}$ Signe-Mary McKernan, Caroline Ratcliffe, Eugene Steuerle, and Sisi Zhang. "Less than Equal: Racial Disparities in Wealth Accumulation", Urban Institute, April 13, 2013. http://www .urban.org/sites/default/files/alfresco/publication-pdfs/412802Less-Than-Equal-Racial-Disparities-in-Wealth-Accumulation.PDF. See also Morrissey, "White workers." See Lazonick, Sustainable Prosperity in the New Economy? Ch. 4.

${ }^{64}$ Rebecca Tippett, Avis Jones-DeWeever, Maya Rockeymoore, Darrick Hamilton, and William Darity Jr., "Beyond Broke: Why Closing the Racial Wealth Gap is a Priority for National Economic Security." Center for Global Policy Solutions, $2014: 10$ Figure 2, at https://www.issuelab.org/resources/18126/18126.pdf. Morrissey and the Urban Institute researchers use the Survey of Consumer Finances, while Tippet et al. use the Survey of Income and Program Participation.

${ }^{65}$ Tippet et al., "Beyond Broke," p. 12, Figure 3.

${ }^{66}$ McKernan, et al., "Less than Equal," Figure 5.
} 
wealth between whites, Blacks and Latinos. ${ }^{67}$ The degree of inequality is staggering. As of the third quarter of 2019, the percent of all corporate equity and mutual fund value owned by each group was 92.1 percent for white households, 1.5 percent for Black households, and 1.9 percent for Hispanic households. This amounts to $\$ 23.11$ trillion in dollar value for white households, $\$ 0.38$ trillion for Black households, and \$0.49 trillion for Hispanic households. ${ }^{68}$

To calculate the flow of income payments from owning stock to whites, blacks and Latinos, Palladino uses data from Federal Reserve's Distributional Financial Accounts on stock ownership by race and information from the Standard \&Poor's Compustat database to calculate a total of shareholder payments. Payments include cash dividends and value of stock buybacks. She summarizes her findings as follows: "I find a Black-white ratio of 0.013 and a Hispanic-white ratio of 0.016 for total shareholder payments made over the period from Q1 2004 to Q2 2019. Total shareholder payments made to white households during that time frame totaled $\$ 13$ trillion, while $\$ 181$ billion went to Black households and \$212 billion to Hispanic households." 69

Finally, Palladino estimates the contribution of the disparity in the ownership of corporate equity by race to the overall racial gap in wealth over time. She does this by calculating the ratio over time of the racial difference in corporate equity wealth to the total racial difference in wealth. She finds that this ratio was 15 percent in 1995, but by 2019 it had reached 23 percent. $^{70}$

An important and growing negative component of wealth is student debt. This problem looms for all groups of Americans who lack sufficient resources to finance the increasing cost of higher education. Student debt delays the ability to save and, we expect, influences the jobs people take because they must start paying down debt as soon as possible. As with other components of wealth, student debt hits African Americans significantly harder than whites. ${ }^{71}$ Figure II.21 gives the time path of student debt from 1989 and clearly indicates a growing gap in the degree of indebtedness between Blacks and whites. ${ }^{72}$

Student-loan debt for Blacks began to outpace that for whites after 2000 as a greater fraction of Black families took loans for college than did white families. Among families headed by an adult aged 25 to 55 in 2016, 42 percent of Black families carried student-loan debt compared to 34 percent of white families. ${ }^{73}$ This difference is no doubt a consequence of lower earnings in Black families and the significantly lower wealth held by Black families that we show in this section. Black families are consequently less able to give and less likely to receive wealth as transfers and

\footnotetext{
${ }^{67}$ Lenore Palladino, "The Contribution of Shareholder Primacy to the Racial Wealth Gap," Roosevelt Institute Working Paper, February 20, 2020, at https://rooseveltinstitute.org/shareholder-primacy-racial-wealth-gap/.

${ }^{68}$ Ibid.: 2

${ }^{69}$ Ibid.: 14

${ }^{70}$ Ibid.: 15

${ }^{71}$ The relatively higher burden of student debt that Blacks face is rooted in part in the long history of fewer resources available for Black public schools and the lower educational achievement levels that Blacks have been able to realize, as well as the differential job opportunities and lower family incomes that Blacks have always endured. This is the argument in Darrick Hamilton and William A. Darity Jr., "The Political Economy of Education, Financial Literacy, and the Racial Wealth Gap," Federal Reserve Bank of St. Louis Review, First Quarter, 99, 1, 2017: 59-76. We discuss the more recent history of disparate educational resources and achievement in Working Paper \#5.

${ }^{72}$ Urban Institute, "Nine Charts," Chart 8.

${ }^{73}$ Ibid. Text accompanying Chart 8.
} 
gifts. ${ }^{74}$ Finally, Blacks entering college have lower graduation rates than whites, which results in lower paying jobs on average than whites who enter college.

Figure II.21: Average student loan debt for those ages 25-55, 1989-2016

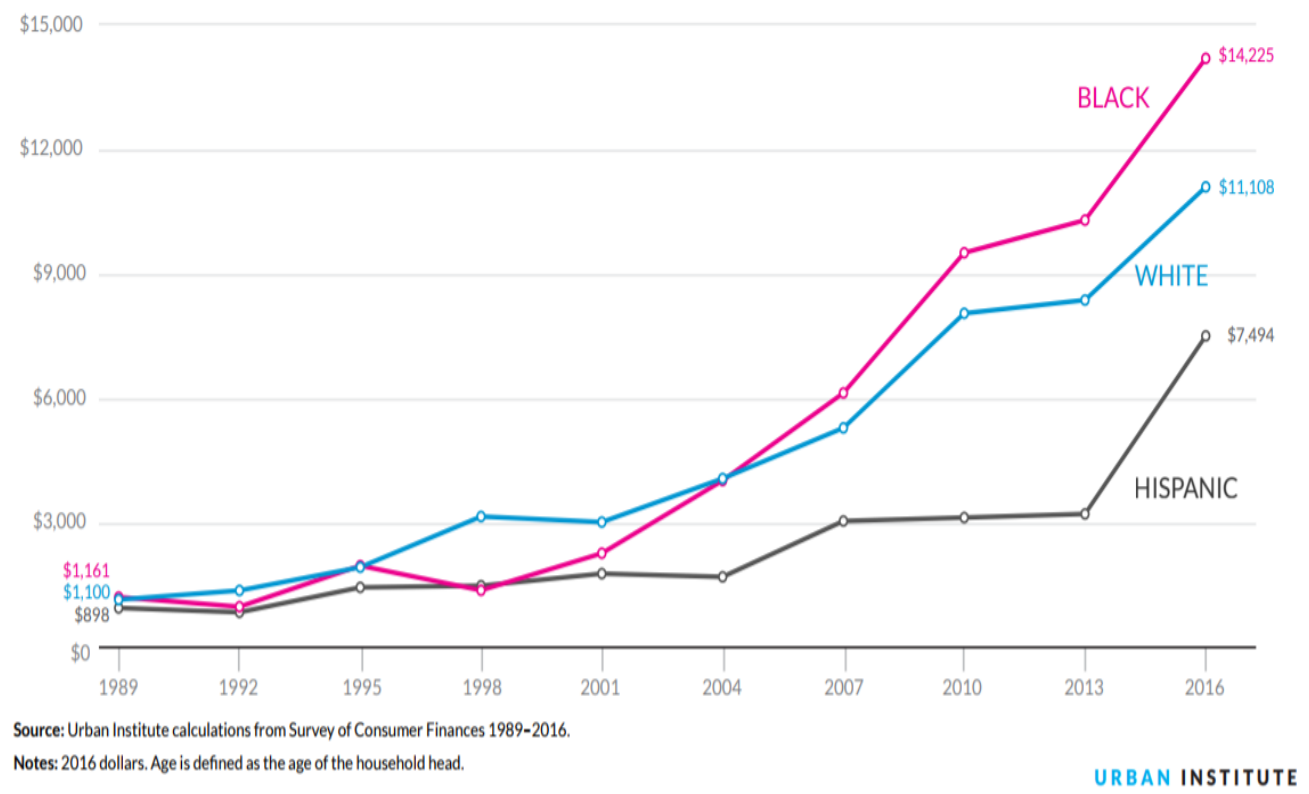

This gap makes paying off student debt even more difficult for Blacks. Since 2000, the difference in college graduation rates between Blacks and whites has grown. For the cohort of students entering a four-year college in 1996, the graduation rate for whites was 36.0 percent and for the cohort entering in 2009 the rate grew to 44.0 percent. The cohort of Blacks entering a four-year college in 1996 had a 19.5 percent graduation rate and for the 2009 entering cohort, the rate grew only to 20.6 percent. ${ }^{75}$

To compound the differential burden of student debt, Blacks were hit much harder than whites during this time by the now well-publicized problem of accumulated debt burden without graduation from for-profit schools. Looking again at the 1996 and 2009 cohorts entering four-year colleges, both whites and Blacks had low and falling graduation rates from for-profit schools. The white graduation rate from for-profit schools fell from 26.3 percent to 21.3 percent, while the graduation rate for Blacks plummeted from 14.8 percent to a shocking 7.6 percent. ${ }^{76}$ In addition to these alarmingly low rates of graduation, research has shown the damaging effect that for-profit schools have had on running up student debt and its effect on the future prospects of attendees in general $^{77}$ and for Blacks in particular.

\footnotetext{
${ }^{74}$ Signe-Mary McKernan, Caroline Ratcliffe, Margaret Simms, Sisi Zhang "Private Transfers, Race, and Wealth," The Urban Institute, August 11, 2011, at https://www.urban.org/research/publication/private-transfers-race-and-wealth/view/full report

${ }^{75}$ National Center for Educational Statistics, Digest of Education Statistics, 2016 Tables and Figures, Table 326.10. Graduation rate from first institution attended for first-time, full-time bachelor's degree- seeking students at 4-year postsecondary institutions, by race/ethnicity, time to completion, sex, control of institution, and acceptance rate: Selected cohort entry years, 1996 through 2009, at https://nces.ed.gov/programs/digest/d16/tables/dt16 326.10.asp? current=yes.

${ }^{76}$ Ibid.

${ }^{77}$ Luis Armona, Rajashri Chakrabarti, and Michael F. Lovenheim analyze data from five sources to compare the experiences of attendees at for-profit institutions compared to public universities. They show that "Students who attend for-profit institutions take on more educational debt, have worse labor market outcomes, and are more likely to default than students attending
} 
Judith Scott-Clayton, using relatively new data from the U.S. Department of Education, reports that "debt and default among Black college students is at crisis levels, and even a bachelor's degree is no guarantee of security: Black BA graduates default at five times the rate of white BA graduates (21 versus 4 percent), and are more likely to default than white dropouts." 78 Highlighting the glaring dropout rates for Blacks at for-profit schools we report above, Scott-Clayton also shows that "defaults have also risen most rapidly among students who never complete an associate's or bachelor's degree" and that this outcome is caused by low earnings rather than by the size of the debt incurred. ${ }^{79}$

Peter Temin discusses how federal as well as state-level education policies contributed to the racial gap in access to higher education. In addition, he reports on the effects of federal deregulation policies that resulted in the privatization of student debt, the rise of for-profit colleges and role that for-profit colleges played in generating large debt burdens with fraudulent promises of well-paid employment following graduation. Temin uses the term "racecraft" to refer to government policies whose intent or effect is to disadvantage Blacks. ${ }^{80}$

\section{Health insurance}

Health insurance access has increased under the Affordable Care Act, but there are still important differences in coverage of Blacks and whites. Figure II.22, from the Kaiser Foundation, indicates that in 2014, compared with whites, a higher percentage of Blacks were uninsured, a much lower percentage were insured through their employer or another private insurer, and a significantly higher percentage were on Medicaid or another government insurance plan. ${ }^{81}$ This disparity clearly reflects differential experience in employment. Blacks are much more likely to be working for an employer who does not provide health insurance but have wages low enough to be eligible for Medicaid.

similarly-selective public schools [...and] tend to serve students from more disadvantaged backgrounds, [...]Among four-year students, for[-]profit enrollment leads to more loans, higher loan amounts, an increased likelihood of borrowing, an increased risk of default and worse labor market outcomes. Two-year for-profit students also take out more loans, have higher default rates and lower earnings." Luis Armona, Rajashri Chakrabarti, and Michael F. Lovenheim, "How Does For-profit College Attendance Affect Student Loans, Defaults and Labor Market Outcomes?” NBER Working Paper No. 25042, September 2018.

${ }^{78}$ Judith Scott-Clayton, “The Looming Student Loan Default Crisis is Worse than We Thought," The Brookings Institution, Evidence Speaks Series, January 11, 2018, at https://www.brookings.edu/research/the-looming-student-loan-default-crisis-isworse-than-we-thought/

${ }^{79}$ Ibid.

${ }^{80}$ Peter Temin, "The American Dual Economy: Race, Globalization, and the Politics of Exclusion" Institute for New Economic Thinking, Working Paper 26, November 2015. Temin has expanded his exposition in The Vanishing Middle Class: Prejudice and Power in a Dual Economy, MIT Press, 2017. See also James B. Steele and Lance Williams "Who got rich off the student debt crisis?", Reveal, June 28, 2016, at https://www .revealnews.org/article/who-got-rich-off-the-student-debt-crisis/. See also Thomas Ferguson, Jie Chen, and Paul Jorgensen, "Fifty Shades of Green: High Finance, Political Money, and the U.S.

Congress," Roosevelt Institute, May 2017, at https://rooseveltinstitute.org/fifty-shades-green/.

81 "Key Facts on Health and Health Care by Race and Ethnicity, Kaiser Family Foundation," 2016: Section 4: Health Coverage, Exhibit 4.1, at http://kff.org/report-section/key-facts-on-health-and-health-care-by-race-and-ethnicity-section-4-healthcoverage/ 
Figure II.22: Health insurance coverage of nonelderly population by race/ethnicity, 2014

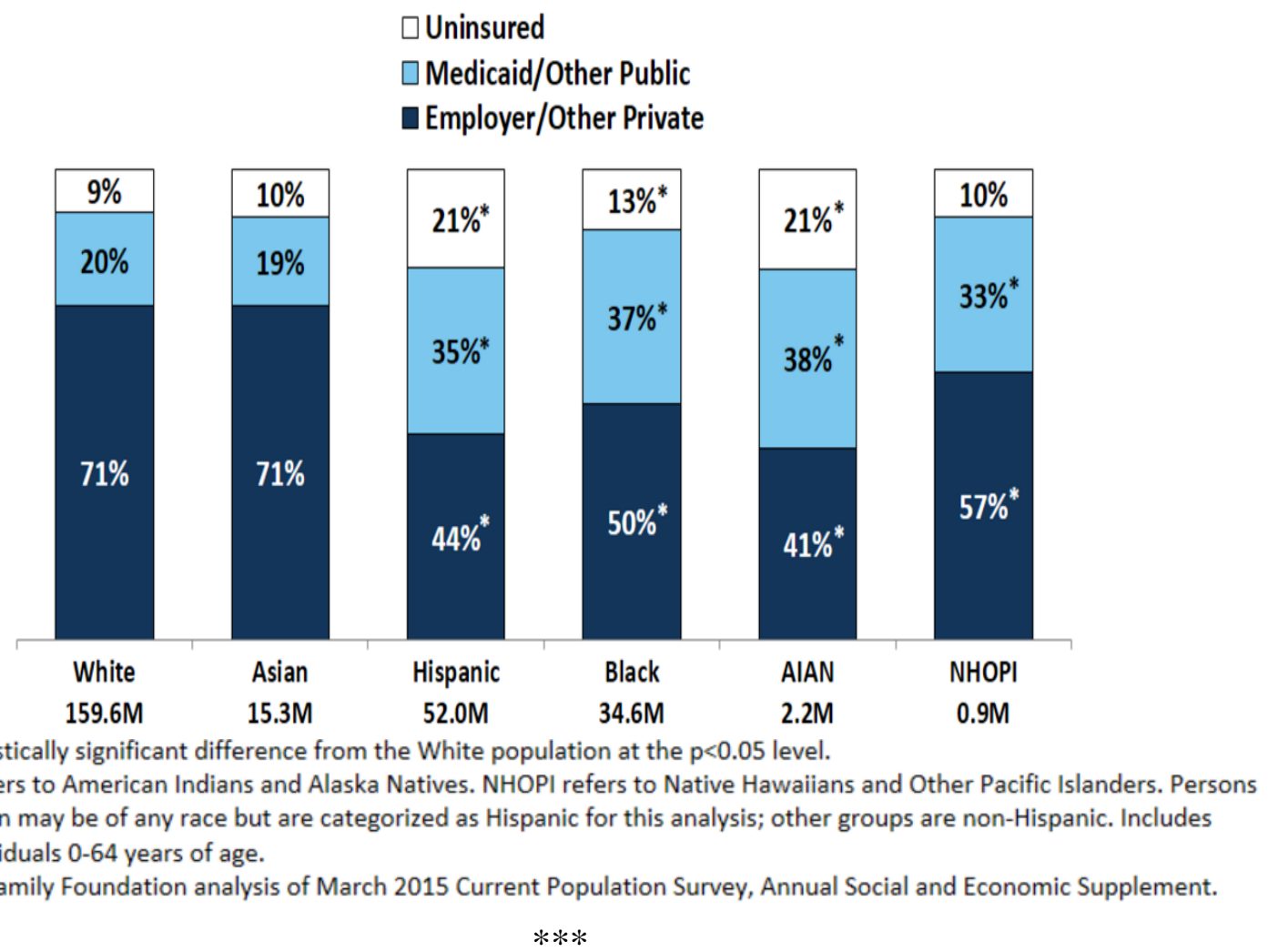

This, then, is the picture of the disparities in jobs, earnings, education, wages, unemployment and accumulated wealth between Blacks and whites fifty years after the Civil Rights Act was passed. In the working papers that follow, we provide an explanation, rooted in employment opportunity, of why such stark disparities exist and persist. Working Paper \#3, to follow, provides an historical perspective on Black employment in the U.S. economy from the late nineteenth century and then focuses on the emergence of a Black blue-collar middle class in the 1960s and 1970s when Blacks started moving into well-paid and stable operative jobs in unionized mass-production industries. Bolstered by the Civil Rights Act and the creation of the EEOC, buoyant labor markets and a corporate-governance structure that accepted stable career employment as a norm enabled the upward socioeconomic mobility of a significant proportion of the high-school-educated Black population.

In the 1980s and beyond, however, the emergent blue-collar middle class would be beaten down by what we have called the "equal employment opportunity omission" in the EEOC that major U.S. business corporations would provide employees, blue collar as well as white-collar, careers with one company. In Working Papers \#4 and \#5, we will analyze the erosion from the 1980s of the corporate norm of a career with one company and its implications

\footnotetext{
${ }^{82}$ William Lazonick, Philip Moss, and Joshua Weitz, “The Equal Employment Opportunity Omission,” Institute for New Economic Thinking Working Paper No. 53, December 5, 2016, at https://www.ineteconomics.org/research/researchpapers/the-equal-employment-opportunity-omission.
} 
for the downward socioeconomic mobility of the U.S. blue-collar labor force-first Black and then white. How can our society achieve equal employment opportunity when there is so little employment opportunity to equalize? And why, in the United States, did employment opportunity for so many disappear? 


\section{References}

Armona, Luis, Rajashri Chakrabarti, and Michael F. Lovenheim, "How Does For-profit College Attendance Affect Student Loans, Defaults and Labor Market Outcomes?” NBER Working Paper No. 25042, September 2018.

Aughinbaugh, Alison, "Patterns of homeownership, delinquency, and foreclosure among youngest baby boomers", Bureau of Labor Statistics, Beyond the Numbers, 2, 2, February 2013, Chart 4, at http://www.bls.gov/opub/btn/volume-2/patterns-of-homeownership.htm.

Buffie Nick, "The Problem of Black Unemployment: Racial Inequalities Persist Even Amongst the Unemployed" , Center for Economic Policy Research, November 2015: Figures 1 and 3, at http://cepr.net/blogs/cepr-blog/the-problem-of-Black-unemployment-racial-inequalitiespersist-even-amongst-the-unemployed Figure 1.

Burd-Sharps, Sarah, and Rebecca Rasch, "Impact of the US Housing Crisis on the Racial Wealth Gap Across Generations.” Social Science Research Council, 2015: p. 11, Figures 3a and 3b, at https://s3 .amazonaws.com/ssrc-cdn1/crmuploads/new publication 3/\% 7B129CDF741F11-E511-940A-005056AB4B80\%7D.pdf

Cooper, David. Mary Gable, and Algernon Austin "The Public-Sector Jobs Crisis: Women and African Americans Hit Hardest by Job Losses in State and Local Governments," Economic Policy Institute Briefing Paper \#339, May 2012: Figure B, at https://www .epi.org/publication/bp339-public-sector-jobs-crisis/.

Economic Policy Institute, State of Working America, "Data Library," at https://www.epi.org/data/\#cpsasec.

Economic Report of the President 2018, Table B-14: Employees on nonagricultural payrolls, by major industry, 1974-2017.

Equal Employment Opportunity Commission, “Types of Discrimination: Race/Color" https://www.eeoc.gov/laws/types/race color.cfm

Farber, Henry, "Job Loss and the Decline of Job Security in the United States," in Katharine G. Abraham, James R. Spletzer, and Michael Harper, eds. Labor in the New Economy, University of Chicago Press, 2010: 223-262.

Ferguson, Thomas, Jie Chen, and Paul Jorgensen, "Fifty Shades of Green: High Finance, Political Money, and the U.S. Congress," Roosevelt Institute, May 2017, at https://rooseveltinstitute.org/fifty-shades-green/.

Ford, Tiffany, Sarah Reber, and Richard V. Reeves, "Race gaps in COVID-19 deaths are even bigger than they appear," Brookings, June 16, 2020, at https://www.brookings.edu/blog/upfront/2020/06/16/race-gaps-in-Covid-19-deaths-are-even-bigger-than-they-appear/

Galbraith, James K., “A Comment on Servaas Storm's 'The New Normal',' International Journal of Political Economy, 46, 4, 2017: 211-216;

Gardner, Todd, "The Racial and Ethnic Composition of Local Government Employees in Large Metro Areas, 1960-2010", Center for Economic Studies, U.S. Department of the Census, 2012, at https://www2.census.gov/ces/wp/2013/CES-WP-13-38.pdf .

Hamilton, Darrick, Algernon Austin and William Darity, Jr., "Whiter Jobs, Higher Wages: Occupational Segregation and the Lower Wages of Black Men," Economic Policy Institute Briefing Paper 288, February 2011, at https://www.epi.org/publication/whiter jobs higher wages/.

Hamilton, Darrick, and William A. Darity Jr., "The Political Economy of Education, Financial Literacy, and the Racial Wealth Gap," Federal Reserve Bank of St. Louis Review, First Quarter, 99, 1, 2017: 59-76. 
Heilbron, Johan, Jochem Verheul, and Sander Quak, "The Origins and Early Diffusion of 'Shareholder Value' in the United States," Theory and Society, 43, 1, 2014: 1-22.

Hogan, Lloyd, and Harry Harris, "The Occupational-Industrial Structure of Black Employment in the United States", Review of Black Political Economy, 6, 1, 1974, pp. 21-23, Table 7. Hopkins, Matt, and William Lazonick, "Who Invests in the High-Tech Knowledge Base?"

Institute for New Economic Thinking Working Group on the Political Economy of Distribution Working Paper No. 6, September 2014 (revised December 2014), at http://ineteconomics.org/ideas-papers/research-papers/who-invests-in-the-high-techknowledge-base.

Jeffress, Philip W., The Negro in the Urban Transit Industry. Philadelphia: Industrial Research Unit, Dept. of Industry, Wharton School of Finance and Commerce, University of Pennsylvania; 1970.

Kaiser Family Foundation, "Key Facts on Health and Health Care by Race and Ethnicity," Kaiser Family Foundation, 2016: Section 4: Health Coverage, Exhibit 4.1, at http://kff.org/report-section/key-facts-on-health-and-health-care-by-race-and-ethnicitysection-4-health-coverage/

Katznelson, Ira, When Affirmative Action Was White: An Untold History of Racial Inequality in Twentieth-Century America, W. W. Norton, 2005.

Lazonick, William, "Is the Most Unproductive Firm the Foundation of the Most Efficient

Economy?: Penrosian Learning Confronts the Neoclassical Fallacy," Institute for New Economic Thinking Working Paper No.111, January 31, 2020, at https://www.ineteconomics.org/research/research-papers/is-the-most-unproductive-firm-thefoundation-of-the-most-efficient-economy-penrosian-learning-confronts-the-neoclassicalfallacy.

Lazonick, William, "Labor in the Twenty-First Century: The Top 0.1\% and the Disappearing Middle Class," in Christian E. Weller, ed., Inequality, Uncertainty, and Opportunity: The Varied and Growing Role of Finance in Labor Relations, Cornell University Press, 2015: 143-192.

Lazonick, William, "Stock Buybacks: From Retain-and-Reinvest to Downsize-and-Distribute," Center for Effective Public Management, Brookings Institution, April 2015, pp. 10-11, at http://www.brookings.edu/research/papers/2015/04/17-stock-buybacks-lazonick.

Lazonick, William, "The Innovative Firm," in Jan Fagerberg, David Mowery, and Richard Nelson, eds., The Oxford Handbook of Innovation, Oxford University Press, 2005: 29-55 Lazonick, William, "The New Normal is 'Maximizing Shareholder Value': Predatory Value Extraction, Slowing Productivity, and the Vanishing American Middle Class," International Journal of Political Economy, 46, 4, 2017; 217-226.

Lazonick, William, "The Theory of Innovative Enterprise: Methodology, Ideology, and Institutions," in Jamee K. Moudud, Cyrus Bina and Patrick L. Mason, eds., Alternative Theories of Competition: Challenges to the Orthodoxy, Routledge, 2012: 127-159;

Lazonick, William, and Mary O'Sullivan, "Maximizing Shareholder Value: A New Ideology for Corporate Governance," Economy and Society, 29, 1, 2000: 13-35.

Lazonick, William, Philip Moss, and Joshua Weitz, "How the Disappearance of Unionized Jobs Obliterated an Emergent Black Middle Class,” Institute for New Economic Thinking Working Paper No. 125, June 2020, at https://www.ineteconomics.org/research/researchpapers/how-the-disappearance-of-unionized-jobs-obliterated-an-emergent-Black-middleclass. 
Lazonick, William, Philip Moss, and Joshua Weitz, "The Equal Employment Opportunity Omission," Institute for New Economic Thinking Working Paper No. 53, December 5, 2016, at https://www.ineteconomics.org/research/research-papers/the-equal-employmentopportunity-omission.

Lazonick, William, Philip Moss, Hal Salzman, and Öner Tulum, "Skill Development and Sustainable Prosperity: Cumulative and Collective Careers versus Skill-Biased Technical Change", INET Working Paper Number 15, December 2014, at https://www.ineteconomics.org/research/research-papers/skill-development-and-sustainableprosperity-cumulative-and-collective-careers-versus-skill-biased-technical-change.

Lazonick, William, Sustainable Prosperity in the New Economy? Business Organization and High-Tech Employment in the United States, Upjohn Institute for Employment Research, 2009, ch. 1, at https://research.upjohn.org/up press/13/.

Leigh, Wilhelmina, and Daniel Huff, "African Americans and Homeownership: The Subprime Lending Experience, 1995 to 2007,” Washington, D. C.: Joint Center for Political and Economic Studies, November 2007.

McKernan, Signe-Mary, Caroline Ratcliffe, Eugene Steuerle, and Sisi Zhang. "Less than Equal: Racial Disparities in Wealth Accumulation”, Urban Institute, April 13, 2013. http://www.urban.org/sites/default/files/alfresco/publication-pdfs/412802-Less-Than-EqualRacial-Disparities-in-Wealth-Accumulation.PDF.

McKernan, Signe-Mary, Caroline Ratcliffe, Margaret Simms, Sisi Zhang "Private Transfers, Race, and Wealth," The Urban Institute, August 11, 2011, at https://www.urban.org/research/publication/private-transfers-race-andwealth/view/full report

Morrissey, Monique, "White workers have nearly five times as much wealth in retirement accounts as Black workers", Economic Policy Institute, February 18, 2016. https://www .epi.org/publication/white-workers-have-nearly-five-times-as-much-wealth-inretirement-accounts-as-Black-workers/

National Center for Educational Statistics, Digest of Education Statistics, 2016 Tables and Figures, Table 326.10, at https://nces.ed.gov/programs/digest/d16/tables/dt16 326.10.asp?current=yes.

Noe-Bustamante, Luis, "Education levels of recent Latino immigrants in the U.S. reached new highs as of 2018," Pew Research Center, April 7, 2020, at https://www.pewresearch.org/facttank/2020/04/07/education-levels-of-recent-latino-immigrants-in-the-u-s-reached-new-highsas-of-2018/.

Northrup, Herbert, Negro Employment in Land and Air Transport; a Study of Racial Policies in the Railroad, Airline, Trucking, and Urban Transit Industries, Industrial Research Unit, Wharton School of Finance and Commerce, University of Pennsylvania, 1971.

Oppel, Jr., Richard A., Robert Gebeloff, K. K. Rebecca Lai, Will Wright, and Rich Smith, "The fullest look yet at the racial inequity of coronavirus," New York Times, July 5, 2020, at https://www.nytimes.com/interactive/2020/07/05/us/coronavirus-latinos-african-americanscdc-data.html

Palladino, Lenore, "The Contribution of Shareholder Primacy to the Racial Wealth Gap," Roosevelt Institute Working Paper, February 20, 2020, at https://rooseveltinstitute.org/shareholder-primacy-racial-wealth-gap/.

Pew Research Center, "America's Shrinking Middle Class: A Close Look at Changes Within Metropolitan Areas", Pew Research Center, May 11, 2016, at 
http://www.pewsocialtrends.org/2016/05/11/americas-shrinking-middle-class-a-close-lookat-changes-within-metropolitan-areas/.

Piore, Michael J., Birds of Passage: Migrant Labor and Industrial Societies, Oxford University Press, 1980.

Ross, Martha, and Nicole Bateman, "Meet the Low-Wage Workforce," Brookings Institution Metropolitan Policy Program, November 7, 2019, at https://www.brookings.edu/research/meet-the-low-wage-workforce/.

Rothstein, Richard, The Color of Law, Liveright Publishing Company, 2017

Scott-Clayton, Judith, "The Looming Student Loan Default Crisis is Worse than We Thought," The Brookings Institution, Evidence Speaks Series, January 11, 2018, at https://www.brookings.edu/research/the-looming-student-loan-default-crisis-is-worse-thanwe-thought/

Serkez, Yaryna, "Who Is most likely to die from the coronavirus?" New York Times, June 4, 2020, at https://www.nytimes.com/interactive/2020/06/04/opinion/coronavirus-health-raceinequality.html?referringSource=articleSharel=

Smith, Karen E., "Low pension participation among minorities contributes to the wealth gap," Urban Institute, April 13, 2015, at https://www.urban.org/urban-wire/low-pensionparticipation-among-minorities-contributes-wealth-gap.

Solomon, Danyelle, Connor Maxwell, and Abril Castro, "Systematic Inequality and Economic Opportunity," Center for American Progress, August 7, 2019, at https://www.americanprogress.org/issues/race/reports/2019/08/07/472910/systematicinequality-economic-opportunity/.

Steele, James B., and Lance Williams "Who got rich off the student debt crisis?", Reveal, June 28, 2016, at https://www.revealnews.org/article/who-got-rich-off-the-student-debt-crisis/.

Storm, Servaas, "The New Normal: Demand, Secular Stagnation, and the Vanishing Middle Class: A Reply to James K. Galbraith and William Lazonick," International Journal of Political Economy, 46, 4, 2017: 227-232.

Storm, Servaas, "The New Normal: Demand, Secular Stagnation, and the Vanishing Middle Class," International Journal of Political Economy, 46, 4, 2017: 169-210.

Temin, Peter, "The American Dual Economy: Race, Globalization, and the Politics of Exclusion" Institute for New Economic Thinking, Working Paper 26, November 2015. Temin, Peter, The Vanishing Middle Class: Prejudice and Power in a Dual Economy, MIT Press, 2017.

Tippett, Rebecca, Avis Jones-DeWeever, Maya Rockeymoore, Darrick Hamilton, and William Darity Jr., "Beyond Broke: Why Closing the Racial Wealth Gap is a Priority for National Economic Security." Center for Global Policy Solutions, 2014: 10 Figure 2, at https://www.issuelab.org/resources/18126/18126.pdf.

U.S. Bureau of Labor Statistics, BLS Reports, "Labor force characteristics by race and ethnicity 2016", October 2017: Chart 5, at https://www.bls.gov/opub/reports/race-andethnicity/2016/home.htm

U.S. Bureau of Labor Statistics, BLS Reports, "Labor force characteristics by race and ethnicity, 2018", https://www.bls.gov/opub/reports/race-and-ethnicity/2018/home.htm

U.S. Bureau of Labor Statistics, Employment Projections, Bureau of Labor Statistics: Table 6, Occupations with the most job growth, 2014-24, https://www.bls.gov/news .release/ecopro.t06.htm 
U.S. Bureau of Labor Statistics, Occupational Outlook Handbook, http://www.bls.gov/ooh/home.htm.

U.S. Census Bureau, "Educational Attainment in the U.S” U.S. Census Bureau, March 2017:

Figures 7 and 8, at https://www.census.gov/library/visualizations/time-series/demo/cpshistorical-time-series.html.

U.S. Census Bureau, "Quick Facts: Population estimates, July 1, 2019," at https://www.census.gov/quickfacts/fact/table/US/PST045219.

U.S. Department of Labor, "The African-American Labor Force in the Recovery," U.S. Department of Labor, February 2012: Figures 1 and 8. https://www.census.gov/hhes/socdemo/education/data/cps/historical/index.html

Urban Institute, "Nine Charts about Wealth Inequality in America (Updated)," October 2017, at http://apps.urban.org/features/wealth-inequality-charts/ Chart 5.

Urban Institute, Metro Trends, "The Racial and Ethnic Composition of Local Government Employees in Large Metro Areas, 1960-2010," 2012, at http://www.metrotrends.org/commentary/race-and-local-government.cfm

Ward, Beverly G., and Eric T. Hill, "Women in Transit: Findings from African-Americans, Other Minorities, and Women in the Transit Industry," Women's Travel Issues, Proceedings From The Second National Conference, Chapter 32 October 1996: 581-

629 at https://www.fhwa.dot.gov/ohim/womens/chap32.pdf.

Whyte Jr., William H., The Organization Man, Simon \& Schuster, 1956.

Wilson, Valerie, and William M. Rodgers III, "Black-White Wage Gaps Expand with Rising Wage Inequality," Economic Policy Institute, September 2016, at https://www .epi.org/publication/Black-white-wage-gaps-expand-with-rising-wageinequality/ 